\title{
COMPETIÇÃO ENTRE POPULAÇÕES DE MILHO NORMAIS E BRAQUITICAS
}

\author{
EMILIO DA MAIA DE CASTRO \\ ENGENHEIRO AGRÓNOMO
}

Orientador: Prof; Dr. ERNESTO PATERNIANI

Tese apresentada à Escola Superior de Agricultura "Luiz de Queiroz", da Universidade de São Paulo, para obtenção do título de Doutor em Agronomia. Área de Concentração: Genética $\theta$ Melhoramento de Plantas.

\footnotetext{
PIRACICABA

Estado de São Paulo - Brasil

Março, 1983
} 
ii.

Aos meus pais, esposa e. filhos 


\section{AGRADECIMENTOS}

A Empresa Brasileira de Pesquisa Agropecuäria, onde trabalho, pela oportunidade oferecida para a realização do curso.

Aos professores e funcionários do Departamento de Genética da Escola Superior de Agricultura "Luiz de Queiroz", pela cordialidade e atenção com as quais me receberam em seu meio.

Em especial ao Professor Paterniani, pela dedicada orientação durante todo o curso e pela sua consideração e interesse.

A Sociedade Agricola Germinal Ltda., pela ajuda na condução dọ trabalhos de campo, e em especial ao Dr. Rober to Rissi pela sua atenção e colaboração.

Aos colegas Francisco Ivaldo Oliveira Melo e Agostinho Roberto de Abreu, pelo auxílio prestado na análise estatistica dos dados.

Finalmente sou grato a todas as pessoas que, di reta ou indiretamente, contribuiram para a concretização deste trabalho. 
CURRICULUM VITAE

EMILIO DA MATA DE CASTRO, filho de Jairo Ferreira de Castro e Esmeralda da Maia de Castro, nascido na cidade de Uruana, Estado de Goiās, aos 19 dias do mês de julho de 1947.

Formado Engenheiro Agrônomo em 18 de dezembro de 1970 pela Escola Superior de Agricultura de Lavras (ESAL), Minas Gerais, e Mestre em Genética e Melhoramento de Plantas, em 1976, pela Escola Superior de Agricultura "Luiz de Queiroz" (ESALQ), de Piracicaba, São Paulo.

Trabalhou em pesquisa com a cultura do algodoeiro durante todo o período apos formado, no princi pio em Sete Lagoas, Minas Gerais, pelo Departamento Na cional de Pesquisas Agropecuärias (extinto DNPEA) e até os dias atuais pela Empresa Brasileira de Pesquisa Agropecuäria (EMBRAPA), lotado em Uberaba.

A partir de março de 1981 iniciou o curso de Doutorado em Agronomia, com área de concentração em Ge nética e Melhoramento de Plantas, pela ESALQ, da Universidade de São Paulo. 
Pāgina

RESUMO ........................... vii

SUMMARY. . . . . . . . . . . . . . $x$

1. INTRODUÇAO . . . . . . . . . . . . . . .

. 2. . revisáo de literatura. . . . . . . . . . . . . 5

2.1. Potencialidade Produtiva do Milho .... 5

2.2. Relação entre Fonte e Depósito de Metabólitos 10

2.3. Periodo de Enchimento dos Grãos.... . . 20

2.4. Eficiencia Fotossintética ......... 24

2.5. Caracteristicas foliares........ . 29

2.5.1. Desenvolvimento das. Folhas e sua Função. $\quad 29$

2.5.2. Intercepção da Luz Solar. . . . . . 32

2.5.3. Arquitetura foliar....... . . 39

2.6. Prolificidade ................ 50

2.7. Influência do Pendão na Produtividade . . . 55

2.8. Plantas de Porte Baixo. . . . . . . 60

2.8.1. Obtenção de Plantas Baixas ...... 60

2.8.2. Alterações na Planta pelo Carăter Braquitico............... 62

2.8.2.1. Alterações no Calmo da Planta 62

2.8.2.2. Alterações nas caracteristicas Foliares.......... 70

2.8.2.3. Influência na Produção e seus Componentes....... 
2.8.3. Eficiência do Milho Braquítico. ....

2.9. Considerações Gerais. . . . . . . . . 90

3. MATERIAL E METODOS. . . . . . . . . . . . . 91

3.1. Material. ................... 91

3.2. Métodos . . . . . . . . . . . . 95

4." RESULTADOS E DISCUSSAOO . . . . . . . . . 102

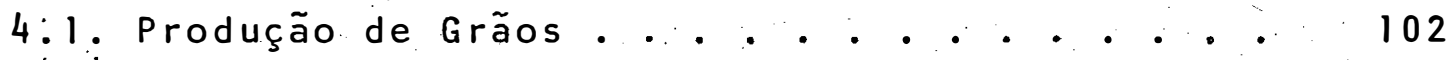

4.2. Acamamento. . . . . . . . . . 107

4.3. Altura da Planta, da Espiga e Tndice AE/AP. . 109

4.4. Nümero de Espigas por Plantas . . . . . . 112

4.5. Florescimento . . . . . . . . . . . 114

4.6. Número de Ramificações do Pendão. . . . . . 116

4.7. Espigas Pendentes . . . . . . . . . . . . 118

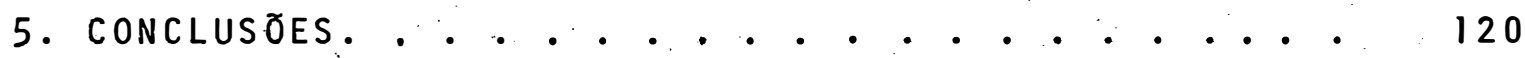

LITERATURA CITADA. . . . . . . . . . . . . 122

APENDICE. . . . . . . . . . . . . . . . . . 143 
.vii.

COMPETIÇÃO ENTRE. POPULAÇOES DE MILHO NORMAISS E BRAQUITICAS

Emizio da Maia de Castro

Prof. Dr. Ernesto Paterniani

- Orientador -

RESUMO

Populações de milho braquíticas, tem sido desen volvidas no Departamento de Genética da ESALQ, como uma solu çao para a obtenção de cultivares de plantas baixạs, mais ef cientes e com maior resistência ao acamamento. No presente tra balho, são comparados materiais braquíticos com as corres pondentes versoes normais.

Para tanto cinco populações de milho de porte normal e cinco braquiticos, foram avaliadas em experimen tos em faixa, com seis repetições em 4 locais em 1981/82. As populações com as correspondentes versões normais e bra quiticas, foram: 1. 'ESALQ VD.2' e 'Piranão VD.2; 2. 'ESALQ VF.1' e 'Piranão VF.1'; 3. 'ESALQ VD.4' e 'Piranão VD.4'; 4. 'ESALQ VF.3' e 'Piranão VF.3'; 5. 'Maya XIII' e 'Mayanão II'. As populações 'VD. $2^{\prime}$ e 'VD. $4^{\prime}$ são de germoplasma Tuxpeño e com grãos denta dos amarelos e brancos, respectivamente. As populações 'VF. I' e 'VF.3' são de germoplasma cristalino da Colômbia, Cuba e Brasil 
e apresentam grãos de cor laranja e de cor branca, respectiva mente. A popuilação 'Maya' desenvolvida pelo Instituro Agronô mico de Campinas, corresponde a um milho dentado amarelo de germoplasma Tuxpeño.

As populações braquíticas foram tão produtivas quanto as normais. As variedades 'Pirañ̃o VD.2', 'Mayanão II' e 'Piranão VF. 3' foram as braquíticas mais produtivas com $99,8 \%, 97,1 \%$ e $99,3 \%$ da população das respectivas formas nor mais. Uma das mais importantes vantagens das formas braquíti cas foi sua maior resistência ao acamamento, uma vez que, en quanto as plantas altas acamáram $33,4 \%$ elas apresentaram apenas $11,8 \%$ de plantas acamadas. Paralelamente apresentaram uma altura média de planta de $169,8 \mathrm{~cm}$ correspondendo a uma redução de $31,0 \%$ das altas. A posição da espiga no caule foi mais mediana $(A E / A P=0,53)$, enquanto nas normais situava-se no terço superior $(\operatorname{AE} / A P=0,63)$. 0 tamanho do pendão sofreu uma re dução de $10,7 \%$ com relação ao nümero de ramificações e a porcentagem de espigas pendentes de $53,9 \%$ nas formas braquíticas. Em termos médios não houve diferença significativa entre os portes para número de dias para o florescimento masculino, intervalo entre o florescimento masculino e feminino e ainda para nümero de espigas por planta.

Pelos resultados encontrados as formas braquíti cas apresentaram vantagens que as tornam recomendáveis para a 
.$i x$.

agricultura brasileira. Assim é que foram tao produtivas quanto as populações normais com as quais foram comparadas que representaram as melhores do País, alëm de serem muito mais resistentes ao acamamento. 
SUMMARY

Brachytic maize populations have been developed at the Department of Genetics of the Escola. Superior de Agricultura "Luiz de Queiroz", Piracicaba, SP., Brazil, as a means to obtain a more desirable plant type with higher resistance to lodging.

The present study was undertaken to compare brachytic vs. normal population. Five normal and the corresponding brachytic counterpart were evaluated in 1981-82 at four locations with six replications per location. The five normal and corresponding brachytic populations were the following: 1. 'ESALQ VD.2' and 'Piranão VD.2'; 2. 'ESALQ VF.1' and 'Piranão VF.1'; 3. 'ESALQ VD.4' and 'Piranão VD.4'; 4. 'ESALQ VF.3' and 'Piranão VF.3'; 5. 'Maya XIII' and 'Mayañ̃o II'. 
yellow and white, respectively, are essentially Tuxpeño dent germoplasm. Populations identified as 'VF.1' and 'VF. 3' deep - yellow and white, respectively, are essentially a combination of Caribbean and Colombian flint germoplasm. 'Maya' is a yellow dent Tuxpeño material developed at the: Instituto Agronômico de Campinas, SP.

The brachytic materials yielded about the same as their normal counterparts. The brachytic types with higher yields were: 'Piranão VD.2', 'Mayanão II' and 'Piranão VF. 3'; that yielded $99,5 \%, 97,1 \%$ and $99,3 \%$, respectively, in relation to their normal versions. The most important advantage of the brachytics certainly is their higher resistance to lodging, the normal tall plants lodged on the average $33,4 \%$, the brachytics lodged only $11,8 \%$. Plant height of the brachytics was on the average $169.8 \mathrm{~cm}$ corresponding to a reduction of $31 \%$ in relation to the tall plants. Ear placement on the brachytics was also lower, since the EH/PH index was of the order of 0,53 while in normal materials the corresponding value was 0.63 . Tassel size evaluated by number of branches was smaller in brachytic maize with a reduction of $10,7 \%$. Flowering time was nearing the same for both normal and brachytic material.

The results pointed out that brachytic maize might be a promissing material for Brasilian conditions. 
-xii.

Outstanding features are: Good grain yields, highest lodging resistance and possibly other agronomic characters that can be incorporated effectively. 


\section{INTRODUÇÃO}

Os processos de cultivo têm experimentado ao lon go dos tempos uma evolução contínua e influido nas caracterís ticas das plantas cultivadas. O milho, objeto deste trabalho, nas regiões trapicais, onde tem sido plantado tradicionalmente em baixos níveis de tecnologia, caracterizados principalmente por espaçamentos largos e controle deficiente das plantas daninhas, evoluiu para um porte alto, crescimento rápido e folhas longas com disposição horizontal. Estas características possivelmente se desenvolveram como uma reação adaptativa que permitiu à planta ocupar e usufruir mais rapidamente o espaço a ela disponível e também competir mais eficientemente com as plantas daninhas com as quais frequentemente foi levada a conviver. 'Em arroz uma situação parecida tem sido observada e ex plicações semelhantes a estas tem sido sugeridas (JENNINGS,1966).

No Brasil, o cultivo do milho vem experimentando um processo acentuado de tecnificação, salientando-se ainda 
a crescente importância de não apenas aumentar a produtividade, mas de reduzir os custos e as perdas a que estão sujeitas as plantas em seu cultivo. Para esta nova situação as variedades, ou híbridos, de porte alto das regiões tropicais podem não ser o tipo de planta ideal. No geral são muito sujeitas ao acamamento e este, pela sua constância e volume de perdas que acarreta, especialmente em caso de colheita mecanizada, cons titui-se em fator de risco muito importante causando prejuízos e tornando a cultura pouco atrativa especialmente para uma agricultura em níveis empresariais.

A seleção de plantas mais resistentés ao acamamento tem conduzido a progressos significativos em relação aos materiais originais. No entanto, em condições de maior ri... gor sempre ocorre acamamento acentuado: A obtenção de plantas de porte baixo, por outro lado, têm se mostrado um meio eficiente de controle do acamamento.

A estatura baixa de plantas tem sido relacionada, em muitas culturas, com maior eficiência fisiológica no aproveitamento do ambiente. Em arroz e trigo, por exemplo, as variedades modernas de alta produtividade têm no porte baixo uma das principais explicações de suas performances. Em milho existem bons motivos para se atribuir às plantas baixas maior eficiência, o que será discutido neste trabalho, embora a bibliografia no geral não leve isto em conta, a não ser: apenas 
a sua maior resistência ao acamamentó.

Uma série de outros caracteres têm sido estudados relacionados a uma maior eficiência da planta do milho, o que é muito interessante. Segundo NASYROV. (1978) na condição atual em que um alto nível técnico na cultura do milho já foi atingido,os ganhos em produtividade têm mostrado uma tendêncià à estabilização, embora os estudos fisiológicos revelem um po tencial muito além dos atuais. Este potencial produtivo deverá ser alcançado com um tipo de planta mais eficiente que o existente e somente será atingido na medida em que os diferentes caracteres relacionados com a produtividade sejam melhor estudados, isoladamente ou integrados harmonicamente em um mesmo genótipo. A altura da planta se insere neste contexto e portanto para entender-se seu relacionamento com os demais, procurar-se-á analisar aqueles mais importantes e melhor estudados pela literatura. Com isot, espera-se ter uma idéia mais abrangente sobre os caracteres de importância bem como da possibilidade de serem utilizados para a criação de um tipo de planta mais adequado aos dias atuais.

Levando-se em conta as considerações feitas, es te trabalho tem como objetivo verificar a viabilidade de algumas populações de milho de porte baixo, obtidas pela introdução do gene braquitico-2, para as condições brasileiras. Pretende também estudar o efeito do referido gene nas respectivas popula- 
çoes baixas em relação às suas originais de porte normal. No geral estes trabalhos têm sido feitos com linhagens ou híbridos, porém pouca informação existe a respeito de seu efeito em populações. 
2.1. Potencialidade Produtiva do"Milho

Vários fatores têm sido reconhecidos como limi tantes à produção, tais como nutrientes, água, pragas, manejo cultural, etc:. Porém,quando eles não são deficientes à planta e economicamente passíveis de serem utilizados nos níveis necessários, resultam em produções elevadas das variedades adap̌a das, passando a produtividade máxima a depender principalmente da taxa de interceptação da 1 uz e da assimilação de $\mathrm{CO}_{2}$ pela superfície da cultura (LOOMIS e Williams, 1963). PENDLETON(1968) observou que em muitas áreas dos Estados. Unidos, onde a produtividade com os germoplasmas atuais é alta, não se tem conseguido acréscimos significativos na produção com o fornecimento adicional de água, nutrientes, $\mathrm{CO}_{2}$, etc. sendo portanto a capa cidade de utilização da luz solar, o faţor limitante mais importante na atualidade. O referido autor chegou a esta conclu são também em função de trabalhos de enriquecimento e empobre- 
cimento em luz solar, do ambiente das plantas. Num trabalho desta natureza, em condições ótimas de nutrição e umidade, PENDLETON et alii (1967) criaram uma condição rica em luz através de uma lâmina de alumínio colocada obliquamente e refletindo os raios luminosos na fileira adjacente. Com isto obtiveram um aumento substancial em produção, chegando a um mâ ximo de $23.710 \mathrm{~kg} / \mathrm{ha}$ de milho. Por outro lado a diminuição da luminosidade tem causàdo reduções acentuadas da produção. EARLY et alii (1967), por exemplo, reduziram-na em torno de: 25 a $30 \%$ com diminuição de $30 \%$ de luminosidade, apenas na fase de maturação dos grãos.

A capacidade de aproveitamento da luz solar pe1o milho, apesar de ser considerada limitante, é.uma das maiores em relação à observada em outras espécies, isto porque ele pertence a um grupo privilegiado de plantas que possui o ciclo $\mathrm{C}_{4}$ de metabolismo do carbono na fotossíntese. Esta caracte rística especial condicionada por modificações fisiológicas e morfológicas das plantas têm sido amplamente estudada. Entretanto para o presente trabalho $\bar{e}$ interessante conhecer pelo me nos alguns aspectos que resultam mais diretamente nesta maior eficiência. As considerações a seguir, a este respeito, se ba seiam nas revisões apresentadas pelos autores MUSGRAVE (1971), WITTER (1974), EVANS e WARDLAW (1976); LAWLOR (1979); MAGALHÃES (1979) e WIT et alii (1979). 
Nas plantas de ciclo $\mathrm{C}_{3}$ o primeiro composto da reação de fixação do $\mathrm{CO}_{2}$ possui 3 átomos de carbono no esquele to de sua cadeia, enquanto que naquelas de ciclo $\mathrm{C}_{4}$ forma-se um com 4 ätomos, do que resultou os respectivos nomes dos dois processos metabólicos. Em ambos ocorre o fenômeno de liberação parcial do $\mathrm{CO}_{2}$ em presença de 1 uz, concomitante à fotos.síntese, sendo que nas plantas $C_{4}$ ele é reaproveitado e nas $C_{3}$ perdido para a atmosfera.. Nas plantas $C_{4}$, por outro lado, jun to aos feixes vasculares forma-se um tecido diferenciado,a baí. nha vascular, a qual possui uma alta concentração de cloroplas tos e é o local onde o $\mathrm{CO}_{2}$ liberado é reaproveitado através de um metabolismo semelhante ao ciclo $C_{3}$ do carbono. Neste caso a fotorespiração não é observada. A assimilação do $\mathrm{CO}_{2}$ se dá ao nível do mesófilo foliar e a liberação de $\mathrm{CO}_{2}$ e seu reapro-: veitamento ao nível da baínha vascular.

A fotorespiração nas plantas $\mathrm{C}_{3}$ pode representar de. 20 a $50 \%$ de perda do $\mathrm{CO}_{2}$ assimilado, perda essa que não ocorre nas plantas de ciclo $\mathrm{C}_{4}$. Esta economia de carbono sem dúvida representa uma das principais vantagens destas ültimas em relação às primeiras. Em milho tem se observado valores pa ra a taxa de fotossíntese líquida, em média, de 50 a $70 \mathrm{mg}$ de $\mathrm{CO}_{2} \cdot \mathrm{dm}^{-2} \cdot \mathrm{h}^{-1}$, enquanto que nas plantas $\mathrm{C}_{3}$ os valores têm se situado em torno de 15 a $35 \mathrm{mg}$ de $\mathrm{CO}_{2} \cdot \mathrm{dm}^{-2} \cdot \mathrm{h}^{-1}$.

Deve-se considerar, entretanto, que a fotossin- 
tese via $\mathrm{C}_{4}$ consome mais energia para cada molécula de $\mathrm{CO}_{2} \mathrm{fi}_{-}$ xada $[5 A T P+2 \dot{N A D}(P) H]$ do que a via $C_{3}[3 A T P+2 N A D(P) H]$. Assim, a maior vantagem da planta $\mathrm{C}_{4}$ ocorre em alta intensidade luminosa e temperaturas mais elevadas. Para condições de céu nubla do ou para folhas sombreadas, como as inferiores, sua taxa fo. tossintética pode ser até mesmo menor,especialmente quando ocor re tambẻm temperaturas mais baixas. A temperatura ótima para a fotossintese nas plantas $\mathrm{C}_{4}$ situa-se em torno de 35 a $40^{\circ} \mathrm{C}$ (sendo negligível abaixo de $12^{\circ} \mathrm{C}$ ) e a taxa de fotossíntese aumenta com a intensidade luminosa, não se saturando mesmo em condições de sua máxima intensidade. Por outro 1 ado, nas plantas $\mathrm{C}_{3}$ a temperatura ótima situa-se em torno de $2.5^{\circ} \mathrm{C}$ (com considerável assimilação mesmo a $0^{\circ} \mathrm{C}$ ) e a saturação pela 1 uz se dà aproximadamente entre $1 / 3$ a $1 / 2$ da intensidadé 1 uminosa mäxima (em torno do meio dia).

Ainda outras características importantes das plantas $\mathrm{C}_{4}$ s $\mathrm{s}$ ö mencionadas:

São capazes de aproveitar o $\mathrm{CO}_{2}$ em níveis mais baixos na atmosfera. MOSS (1962) observou plantas de milho assimilando $\mathrm{CO}_{2}$ a níveis de apenas 9 ppm em volume (o normal é $300 \mathrm{ppm}$ ) enquanto as plantas $C_{3}$ o fazem apenas até níveis em torno de 50 a 150 ppm em volume. Esta característica dá à planta capacidade de competição com outras, quando em comunidades densas onde pode haver 1 imitação de $\mathrm{CO}_{2}$. Apresentam maior 
resistência ao fluxo de $\mathrm{CO}_{2}$ e vapor, e com níveis relativamen te mais baixos de $\mathrm{CO}_{2}$ na atmosfera, já se inicia o controle do fechamento de estômatos, (a metade daquele para as $\mathrm{C}_{3}$ ). MOSS et alii (1961) observaram em experimentos com o milho que pequenos acréscimos de $\mathrm{CO}_{2}$ causaram acentuado fechamento de estômatos diminuindo-se a transpiração sem entretanto causar decréscimo na: assimilação de $\mathrm{CO}_{2}$. Em determinadas condições, as plantas $\mathrm{C}_{4}$ chegam a apresentar $50 \%$ mais eficiência na utilização de água por peso de matéria seca produzida.

Podem produzir duas vezes mais matéria seca por unidade de nitrogênio presente nas folhas graças a um processo mais econômico na utilização de enzimas. Esta característica permite maior eficiência da planta em solos pobres em nitrogênio.

Todas as vantagens relacionadas e que levam o milho a ser considerada uma das mais eficientes plantas no aproveitamento da luz solar, não são suficientes, entretanto, para levá-1o a fixar toda a energia radiante disponível, porém apenas uma parte dela.

Os autores LOOMIS e WILLIAMS (1963) observaram em vārias culturas, que a taxa diāria de acúmulo de matéria se ca situàva-se em torno de 2,0 a $2,5 \%$ do potencial determinado pela luz solar disponível. Os autores calcularam o potencial 
de crescimento em torno de $77 \mathrm{~g} \cdot \mathrm{m}^{-2} \cdot \mathrm{dia}^{-1}$ (34 ton.ha-1 em 100 dias), enquanto que a cana, planta do grupo $\mathrm{C}_{4}$, por exemplo, apresentou um valor em torno de $18 \mathrm{~g} \cdot \mathrm{m}^{-2} \cdot \mathrm{dia}^{-1}$, embora com picos de assimilação bem superior. Em milho com indices de área foliar em torno de 20, um dos maiores observados; WILliams et alii (1965) encontraram, por um período curto de 12 dias, um acúmulo de $52 \mathrm{~g} \cdot \mathrm{m}^{-2} \cdot \mathrm{dia}^{-1}$, correspondendo a uma utilização de 2,9\% da energia radiante. MUSGRAVE (1971) comentando a este respeito, citou trabalhos de Baldock e também de hilson, nos quais os autores demonstraram que o milho fixa apenas $2 \%$ de energia solar enquanto que o potencial de utilização poderia alcançar em torno de $7,1 \%$ da mesma.

. Pelo visto a quantidade de 1 uz disponível não é um fator limitante à cultura, porém o é a capacidade de sua utilização pela mesma. Muitos trabalhos têm sido realizados a respeito de características da planta de milho no sentido de aumentar sua capacidade de aproveitamento da energia solar e a altura da planta deve ser considerada como uma delas, embora a literatura a respeito não a tenha explorado suficientemente.

2.2. Relação entre Fonte e Depōsito de Metabōlitos

A obtenção de um tipo de planta com potencial produtivo maior deve ser precedida de estudos detalhados sobre 
as causas que têm. limitado os avanços pretendidos. Uma das for mas de se estudar o problema é analisar os fatores intrínsecos da planta, pois estes podem eventualmente ser os mais 1 i mitantes em relação aos de seu ambiente externo.

A produção de uma planta vai depender do seu aparato de sintese de matéria orgânica, tambēm chamado "fonte", e da capacidade de armazenagem dos materiais fotossintetizados em sítios determinados, chamados "depósitos". A relação de equilíbrio entre fonte e depósito cria condição de otimização da produção. Entretanto um deles pode ser deficiente e limitante e seu conhecimento é fundamental como orientação ao tra balho de melhoramento de plantas. E mais vantajoso desenvol-... ver-se um maior esforço para os problemas mais limitantes pois desta forma os ganhos podem ser maiores.

Para uma compreensão melhor do problema, fonte e depósito, é interessante discutir-se alguns aspectos básicos relativos à planta. Em primeiro lugar para efeito desta revi são, apenas os grãos serão considerados como depósito. Embora outros órgãos da planta possam eventualmente comportar como tal, de forma permanente (caule e pendão) ou temporáriaj nos quais o seu produto acumulado pode ser remobilizado para os: grãos (HANWAY e RUSSEL, 1969). O milho desenvolve vārias ramificações axilares.laterais (em torno de 6) as quais passam pelo pro cesso de diferenciação floral, porēm não se desenvolvendo ne- 
cessariamente, em espigas (SASS e LOEFFEL, 1959) segundo PRINE (1971), o abortamento de espigas numa planta dá-se de 3 a 4 dias antes da emissão da barba até aproximadamente 8 dias após, constituindo-se este um período altamente crítico ao estabelecimento de espigas. Segundo SIEMER et alii (1969) o pro cesso de paralização da formação de espiguetas ocorre em pri meiro lugar na espiga de posição mais baixa na planta,evoluindo o processo no sentido da superior. Esta, portanto, é a pri meira a florir e a última a sofrer os efeitos da competição por assimilados.

o período da maturação, também chamado período de enchimento dos grãos, estende-se desde o embonecamento até a formação da camada preta. JOHNSON e TANNER (1972) dividiram este período em três fases: Um perỉodo inicial de lento acúmu1o de matéria seca nos grãos (até 15 a 17 dias do embonecamento), um período 1 inear e de intenso aumento em peso representando cerca de $90 \%$ do total do grãos (de \pm 15 a 45 dias do embonecamento) e novamente um período de crescimento mais lento até o ponto de maturação físiológica quando o grão atinge seu peso máximo. o períodolinear de crescimento tem sido chamado de "periodo efetivo de enchimento de grãos". Esta fase final do ciclo das plantas caracteriza-se por uma mobilização de todo o aparato de sintese na geração de fotosintetizados para a formação dos grãos. Observa-se também um aumento do peso do 
caule atē aproximadamente 15 a 20 días após. o embonecamento (MACKINNON, 1979), permanecendo após estável ou caindo no final de enchimento de grãos, o que tem variado com os diferentes trabalhos e genótipos analisados (DAYNARD et alii, 1969). Estes autores observaram reduções significativas no peso do cau le no período do meio para o fim da fase de enchimento dos grãos. Esta queda do peso foi atribuída a uma remobilização de carbohidratos solüveis estocados no caule, para a espiga. DUNCAN et alii (1965) observuram que nas condições de seus estudos. - caule funcionou como um importante órgão de estocagem de açū cares, os quais sob condições, adversas para a planta puderam ser remobilizados para garantir o crescimento dos grãos. Observaram um aumento de peso de grãos relativamente uniforme a despei to da ampla variação da atividade fotossintética a o longo dos dias, o que provavelmente foi garantido pelas reservas do caule. ALLISON e WATSON (1966), por outro lado observaramque o peso seco atingido pelo caule permaneceu constante até o final do ci clo; entretanto em plantas parcialmente desfolhadas ele cai.u a partir do 150 dia do embonecamento através da mobilização: de suas reservas para os grãos.

Pelo que se pode observar a fase reprodutiva e de enchimento dos grãos são bem distintas, uma vez que a primei ra relaciona-se com o estabelecimento do potencial de grãos e a segunda com a efetivação do referido potencial pela mobilização de carbohidratos para os mesmos. Interferências na fase re 
produtiva resultariam em alterações na capacidade de "depósito" da planta e na fase do enchimento de grãos com a "fonte" de assimilados para o suprimento do depósito. No sentido de verifí car se a fonte ou o depósito è o limitante à produção, alguns trabalhos foram realizados através da indução de alterações na capacidade de síntese pela planta nos períodos de floração e de enchimento de grãos. No caso das alterações promovidas ria fase reprodutiva provocarem mudanças na produção da planta, maiores que na fase do enchimento do grãos, então o depósito seria o limitante e em caso conträrio, a fonte.

Uma revisão detalhada a respeito da relação fon te-depósito foi apresentada por TOLlEnAAR (1977) e, segundo este autor, uma série de evidências diretas e indiretas têm demonstrado que para as regiões sub tropicais é temperadas o depó sito é mais Iimitante,enquanto que nas regiões mais frias e de estações de cultivo curtas, a fonte é limitante. EARLY et alii (1967) em Illinois, USA, estudaram o efeito de níveis de sombreamento das folhas em fases diferentes do ciclo da planta observando que estes promoveram reduções muito mais acentuadas na produção quando aplicados na fase de florescimento (55 a 76 dias da germinação) do que nas vegetativas (até 54 dias da germinação) e maturação (de 78 a 140 dias de germinação). Também PRINE (1971) estudando o efeito do desbaste em diferentes fases do ciclo da planta, e, verificando o amento da disponibilidade 
de 1 uz nos indivíduos, sem competição, observou que o período mais crítico à produção ocorreu do início de emissão dos estigmas, ațé 10 a 12 dias após.

Outra indicação do depósito como limitante, é inferida de estudos de acúmulo e distribuição de matéria seca nas plantas. A grande quantidade de matéria seca que permanece no caule e que não é remobilizada para os grãos deve-se a um de pósito deficiente,o que foi observado no trabalho de ALLISON e WATSON (1966) na Rodésia e no trabalho de Goldsworthy e colaboradores, no México, citado por TOLLENAAR (1977).

Nas condições do Norte dos Estados Unidos e no Canadá, os trabalhos a respeito têm indicado a fonte como 1 imi tante. Vários trabalhos realizados nestas regiões têm demonstrado um decréscimo no peso do caule em consequência da remobilização para ós grãos de carbohidratos nele armazenados (HANHAY, 1962; JOHNSON et ali $i$, 1966; HANHAY e RUSSEL, 1969). A remoção das reservas armazenadas no caule para os grãos é indicação de que a fonte de assimilados não estā produzindo suficientemente, sendo portanto a fonte limitante.

TOLLENAAR e DAYNARD (1978) trabalhando numa região de estação de plantio curto, no Canadá, fizeram um estudo de diminuição e de aumento de 1 uz em plantios de milho nas fases de florescimento. (15 dias antes a 15 dias após $50 \%$ de embonecamento) e na maturação ( 15 dias após embonecamento até fase 
de senescência). Concluiram que a fonte foi a limitante, mesmo subestimando a extensão desta 1 imitação, pois produtos estoca dos no caule na fase reprodutiva foram utilizados na de enchimento de grãos. Com uma metodologia diferente, HUNTER

$(1980)$ submeteu um híbrido a foto-períodos de 10 e 20 horas durante o período vegetativo, com o objetivo de obter plantas com nüme ros de folhas diferentes. No início da formação do pendão as plantas foram transferidas para o campo,onde se observou que aquelas submetidas preliminarmente a fotoperíodo maior apresen taram folhas maiores e em maior número, e produções maiores. Segundo o autor seus resultados concordaram com o conceito de que em regiões de estações curtas a fonte è limitante. Para ele estes resultados não foram surpreendentes pois os híbridos das regiões americanas de estações curtas de plantio são caracterizados por plantas de pequeno porte e menor número de folhas.

Em vista das considerações feitas parece lógico que para as condições brasileiras o depósito seja o limitante, embora esta seja uma inferência baseada muito mais em evidências indiretas. De qualquer maneira,os trabalhos sobre a rela ção fonte-depósito são ainda reduzidos com o milho e as metodó logias de estudo ainda não estão bem definidas para conclusões sobre a importância relativa da fonte e do depósito.

A seleção feita pelo homem, de acordo com NASYRov 
(1978), tem sido orientada para a capacidade de depósito da plan ta, o que resultou em aumento da produção até onde a capacidade de fotossintese da planta o permitiu. Em milho a seleção pelo homem para o depósito, foi uma constante em todo seu processo evolutivo. Entretanto deve-se lembrar que a seleção natu ral também atuou paralelamente. Para os milhos tropicais os es paçamentos largos e a competição com plantas daninhas deve ter levado a um aumento na ärea foliar da planta.

Outro aspecto interessante e que demonstra um alto potencial de depósitó se refere às observações de sass e LOEFFEL (1959) segundo os quais, seis a sete espigas iniciam seu desenvolvimento na planta; porëm, a maioria delas cessa seu cres cimento por ocasião da emissão da barba da espiga superior. As plantas, portanto, demonstram um alto potencial para o estabelecimento de um grande depósito, muito embora, apenas una ou poucas espigas superiores consigam se desenvolver.

o potencial maior de produção exibido por cada fase do ciclo das plantas, segundo EVANS e wARDLAW (1976) constitui-se num importante mecanismo de adaptabilidade às flutuações estacionais. Em milho, eventualmente, pode-se observar um maior número de folhas que o aparentemente necessário, o que se infere nos trabalhos com sombreamento de.folhas, nos quais niveis de redução da luminosidade de até 20 a $30 \%$, especialmente na fase vegetativa interferem pouco ou nada. com a produção 
(SCHIMIDT e COLVILLE, 1967; PRINe, 1971). 0. número de espigas que passam pelo processo de diferenciação floral é muito maior ,que o númẹro daquelas que se desenvolvem completamente. Na espiga, o número de espiguetas possíveis é maior que o número de grãos que se formam. Durante o processo de maturação dos grãos, a quantidade de produtos orgânicos produzidos é maior que a necessária, haja visto o alto conteúdo de açúcares no colmo no fi nal do ciclo, o qual, entretanto, pode ser remobilizado para o grãos quando houver problemas com o mecanismo de assimilação. Evidentemente, quanto mais tarde no ciclo da planta ocorrerem situações desfavoráveis, menoṛ a capacidade de recuperação da mesma. Além disto, deve-se considerar a existência de fases crí ticas, quando as reações da planta às alterações do ambiente são mais intensas que nas demais. PRINE (1971) estudando o efeito do desbaste em diferentes fases do ciclo do milho, obser vou que a alta-densidade no período do aparecimento do estígma até 12 dias após, exerceu um efeito muito acentuado na produção de espigas, sendo este o período mais crítico da planta. Sabe-se também que estresses de umidade no período do florescimento são altamente danosos à planta. Este período crítico ocorre numa fase de meio para o fim do ciclo da planta e se relaciona diretamente com a formação do depósito.

- Ao que parece,pelo que se discutiu,ainda não é claramente definido em milho,especialmente para a região trop ca1, qual, se a fonte ou o depósito, é o mais limitante à pro- 
dução. A este respeito TOLLENAAR (1977), em. revisão onde outras culturas também foram levadas em conta, considerou que tanto a fonte como o depósito podem ser limitantes e que combinações particulares do genótipo e ambiente é que determinarão o grau de limitação de cada um. Por outro lado, a existência de mecanismos com efeitos de regulação nos dois sentidos podem nẹu tralizar a importância relativa assumida pela fonte ou depósito. Por exemplo, a fonte de assimilados pode. ajustar-se à demanda dos grãos em crescimento, ou por outro lado, o depósito ser res trito em função de limitações no suprimento de assimilados em fases iniciais de formação dos grãos.

Como ainda não se tem uma idéia precisa sobre a relação fonte-depósito e a produção, a seleção apenas para o caráter considerado mais importante, não parece muito desejável pelo risco envolvido. De qualquer maneira o melhoramento unidirecional para o fator limitante,para o depósito ou fonte, seria muito pouco prático pois haveria uma alternância da importância de cada um no desenrolar do programa,criando a necessida de de uma contínua avaliação para sé conhecer qual deles, num de terminado momento, deve ser considerado. Uma vez que estes fato res estão intimamente relacionados e mutuamente se influenciando, a adoçäo de um melhoramento visando a planta como um todo seria mạ̣s desejāvel e possivelmente levaria à obtenção de genoo tipos mais equilibrados para o grau de influência da fonte ou 
depósito na produção. Assim sendo, genótipos com maior prolifi cidade tanto de grãos quanto de espigas, maior período de enchi mento de grãos, pendões menores, menor intervalo entre o. florescimento masculino e feminino, geometria de folhas mais ade quadas à intercepção da luz solar, maior eficiência fotossintẹ tica por área foliar, etc. deveriam ser obtidos dentro de uma condições de harmonia entre os diferentes caracteres.

\subsection{Periodo de Enchimento dos Grãos}

Uma vez estabelecido o potencial de número de grãos, a produção de uma planta pode ser considerada com função da velocidade e duração do acúmulo de matéria seca nos grãos em formação (PONELETt e EGLI, 1.979). Esta fase durante a qual as sementes se desenvolvem convencionou-se chamar de "periodo de enchimento dos grãos" e ocorre imediatamente após a fertili zação até a maturação fisiológica da semente (camada preta). E ainda interessante considerar que praticamente todo o conteúdo de matéria seca do grão é sintetizado dentro do próprio período, sendo a contribuição das fases anteriores considerada míni ma (ALLISON e WATSON, 1966).

Um estudo mais detalhado do periodo de enchi mento dös grãos foi realizado por JOHNSON e TANNER(1972), os quais o dividiram em três etapas: Um perîodo inicial caracteri 
zado por baixo acümulo de matéria seca e que se estende da emis são da barba até 15 a 17 dias; um outro de acümulo 1 inear de ma téria seca, durante o qual mais de $90 \%$ do peso do grão é incior- porado e tem uma duração de aproximadamente 21 a 27 , e 27: a 32 dias para 1 inhagens e híbridos respectivamente e,finalmente, uma fáse final caracterizada por decréscimo-no acūmulo de matéria seca, terminando com a formação da camada preta.

Tem sido sugerido que o período real de enchimento de grãos seja representado pela fase linear (JOHNSON e TANNER, 1972). Entretanto DAYNARD e KANNENBERG (1976). observa ram em 35 híbridos ava1iados que tanto o perảodo inteiro como somente a fase linear se correlacionaram altamente com a produ ção, podendo serem igualmente utilizados.

Dado à sua importância, o período de enchimento dos grãos tem sido estudado por värios autores. Um interessante trabalho foi desenvolvido por CROSBIE e MOCK (1981) onde pro curaram conhecer as mudanças nas características fisiológicas que permitiram às variedades melhoradas serem superiores às res pectivas originais. Para tanto, avaliaram materiais seleciona dos, em relação aos seus originais, obtidos de três programas de melhoramento dos pesquisadores Dr. Sprague, Dr. Brunson e Dr. Hallauer. Para todos os materiais melhorados foi observado um aumento no período de enchimento de grãos. Em iois dos três ma teriais a taxa de crescimento do grão também foi importante. Ou 
tros parâmetros leyantados também expiicaramos ganhos em produ ção porém não foram constantes para as três populações, senão para uma ou outra delas: Retardamento da senescência, produção maior de matéria seca por planta, peso de grão por área foliar e maior índice de colheita.

Outros autores também têm demonstrado o valor do período de enchimento do grão para o melhoramento através de observações de correlações positivas entre ele e a produ ção (HANWAY e RUSSEL, 1969; DAYNARD et alii, 1971; CROSS, 1975; DAYNARD e KANNENBERG, 1976; PONELEIT e EGLI, 1979 e PONELEIT et $a$ lii, 1980).

o período de enchimento dos grãos apresenta dois componentes que são a sua duração e a taxá ou velocidade de seu crescimento. Quando se aumenta a duração do período, no géral. tem-se uma queda da taxa de crescimento, conforme demonstrado por PONELEIT et alii (1980) em estudos de correlação. A obtenção de plantas mais produtivas pode ocorrer pelo aumento tanto de um como de outro, ou de ambos caracteres, pois embora uma re 1 ação negativa exista, a mesma não se situa em níveis que possam desaçonselhar a seleção. CROSBIE e MOCK (1981) relataram ganhos para produção por seleção e que foram explicados em : um caso por aumento apenas no período de enchimento de grãos,porém em outro tambēm pela taxa de seu enchimento. DAYNARD et ali $i$ (1971) estudaram o comportamento de três hỉbridos e verificaram 
que a diferença em produção entre elès era maior em função da maior duração do período de enchimento dos grãos do que da - taxa de acúmulo de matéria seca dos mesmos. Por outro lado, DAYNARD e KANNENBERG (1976) observaram notáveis excessões pàra a associação entre período de enchimento de grãos e produção. Encontraram híbridos, dentre 35 avaliados, de alta produtivida de e menor período, porém com taxa de enchimento mais elevada, situação esta consideradá bem interessante para a obtenção de plantas precoces. Com relação ao ciclo da planta,pode-se obter plantas com maior período de enchimento de grãos sem alterações do ciclo (PONELEIT et alii , 1980), compensando corn um período menor anterior ao embonecamento.

Pelo visto, existe ampla possibilịdade de se promover alterações na duração e na velocidade de enchimento dos grãos com reflexos positivos na produção. Adicionalmente há bastante variabilidade nas populações para estes dois parâa metros (HANWAY e RUSSEL, 1969; JOHNSON e TANNER,1972). PONELEIT et alii (1980) observaram em 10 populações sintéticas variação de 42 a 91 dias para a duração do período afetivo de enchimen tos dos grãos e 5,5 a $12,8 \mathrm{mg} \cdot \mathrm{grão}^{-1} \cdot$ dia $^{-1}$ para a taxa de enchimento.

Com relação à seleção CRoss (1975) observou que a variação no período de enchimento de grãos se devia principalmente à variância aditiva. Considerando que este caráter 
não è muito influenciado pelo ambiente (PONELEIT e EGLI, 1979) os ganhos por seleção para o mesmo devem ser satisfatórios. Es te autor observou que o aumento da densidade de plantio não afetou a taxa de enchimento do grão, entretanto reduziu o período em 2,5 dias. Por outro 1 ado DAYNARD et alii (1971) não obser vou este efeito da densidade. Com relação aos nutrientes, PEASLEE et alii (1971) não observaram efeitos para àplicações de fósforo, porém um pequeno aumento para a duração do período com as doses de potássio.

\subsection{Eficiência Fotossintética}

A eficiência pela qual a planta assimila $\mathrm{CO}_{2}$, intercepta a luz solar e transloca os compostos orgânicos sintetizados para órgãos. de reserva desenvolvidos, define o seu potencial produtivo. A eficiência fotossintêtica ou de assimilação é portanto um dos principais, senão o maior, componente do potencial produtivo das plantas: 0 milho por possuir fotos síntese do tipo $\mathrm{C}_{4}$ é considerado como uma das plantas mais efi cientes quanto à assimilação de $\mathrm{CO}_{2}$. Entretanto dentro da espécie tem-se observado também uma ampla variação a este respei to. DUNCAN e HESKETH (1968) avaliaram 22 raças de milho e encontraram diferenças entre elas quanto a taxa de fotossíntese por ärea foliar com valores entre 36 a $59 \mathrm{mg}$ de $\mathrm{CO}_{2} \cdot \mathrm{dm}^{-2} \cdot \mathrm{h}^{-1}$. 
Outra evidência da ampla variabilidade'para a eficiência fotossintética em milho foi obtida por HEICHEL e MUSGRAVE (1969), em 1inhagens, hỉbridos e variedades. A taxa de fotossíntese foi deter minada na folha da espiga, três semanas após a polinização. As diferenças entre as linhagens foram mais acentuadas, tendo sido observados os valores de $28 \pm 2$ e $85 \pm 3 \mathrm{mg}$ de $\mathrm{CO}_{2} \cdot \mathrm{dm}^{-2} \cdot \mathrm{h}^{-1}$, para a menos e para a mais eficiente, respectivamente. Observaram também que as diferenças entre variedades, entre híbridos, entre linhagens, ou mesmo entre todos, foram maiores que as dentro de cada material.

A1ém da variação da tasa de assimilação determi nada por fatores genéticos, outros fatores também podem influir e é muito importante que sejam compreendidos para que as medidas visando a otimização da fotossíntese possam ser objetivas. A intensidade da irradiação solar é o fator mais importante pa ra a determinação da eficiência fotossintética de um germoplas ma. MOSS et alii (196I) encontraram uma correlação elevada $(r=0,95)$ entre intensidade luminosa e assimilação de $\mathrm{CO}_{2}$. Os autores observaram com isto que a curva de fotossintese por $\bar{a}-$ rea foliar acompanholi a da intensidade luminosa, com um pico nas horas mais ensolaradas do dia. Observaram, por outro lado que a eficiência de assimilação medida em termos do conteúdo de glucose fixado, e dada em porcentagen da luz solar fixada, - apresentou uma depressão no período do dia de intensidade luminosa mais elevada. Isto significa que $\cdots$ um 
aumento na intensidade luminosa a partir de certo limite produz menos carbohidratos do que o mesmo aumento nos níveis mais baixos. Isto indica que a luz é mais eficientemente utilizada, por unidade de ārea foliar, em níveis mais baixos de luminosidade (EASTIN, 1969). MOCK e PEARCE (1975) revendo trabalhos de diversos autores concluiram que a taxa de fotossintese por área foliar não cresce linearmente com o aumento da intensidade luminosa. Mesmo espécies eficientes, como o milho, conseguem $80 \%$ da fotossintese máximas com apenas $50 \%$ da máxima in-. tensidade luminosa.

Outro fator que interfere na taxa de fotossinte se de uma folha é sua idade. Segundo SESTAK.(1981) ela alcança um máximo um pouco antes da folha atingir seu máximo de área e conteúdo de clorofila, decrescendo posteriormente lentamente com a idade. MUSGRAVE (1971) tambēm observou em 1inha gens de milho este decréscimo com a idade. Outros fatores relacionados com a idade da folha, não intrínsecos da planta,mas do ambiente, vão se acentuando podendo afetar a capacidade de síntese, como por exemplo doenças, pragas, danos mecânicos, acamamento, etc.

Outros fatores têm ainda sido considerados: 0 es tado nutricional da planta afeta a síritese como demonstrado por NUNEZ e KAMPRATH (1969) em ensaios com adubação nitrogenada. Limitações da umidade também foram prejudiciais (Moss et alii, 
1961). Estes mesmos autores consideraram a temperatura como muito importante, uma vez que com seu aumento também cresce a respiração, porēm muito mais a fotossíntese. Outros fatores do ambiente como disponibilidade de água (HESketh e MUSǴRAVE, 196.2), niveis de $\mathrm{CO}_{2}$ (MOSS et alii, 1961; MUSGRAVE,1971), sombreamento prolongado de folhas, neste. caso reduzindo seu poten cial produtivo, mesmo retornando às condições de luminosidade normais (RAVEN et alii, 1981), afetam a.eficiência de síntese das plantas. Entretanto. quando estes fatores se mantém dentro dos nỉveis normais encontrados, a variação na capacidade de fotossintetizar é determinada principalmente pela natureza do genótipo considerado.

A variabilidade genética existentẹ com relação à eficiência fotossintética demonstra por si só a possibilidade de ganho por seleção a este respéito. Segundo MAGAlHães e SILVA (1978) o aumento da produtividade obtida pelo melhoramento, deve ser função de uma maior eficiência de síntese, uma vez que, no geral, não é acompanhado de um aumento corresponden te da ārea dos órgãos fotossintetizantes. A eficiência fotossintética por área foliar foi estudada quanto à sua herdabilidade por CROSBIE (1977), tendo-se observado valores altos para . as mesmas e ainda que a variância aditiva foi a principal res ponsável pela variabilidade do caráter. Num trabalhos posterior, CROSBIE (1981) efetuou cinco ciclos de seleção recorrente feno típica para alta taxa de fotossintese, em duas populações de 
milho, e três ciclos para baixa, em uma delas. Os ganhos foram da ordem de 1,6 e $1,3 \%$ para a taxa de fotosintese por ciclo, para a seleção feita na fase vegetativa e de enchimento de grãos, respectivamente. Os ganhos para baixa eficiência fo ram menores. Por outro 1ado, MUSGRAVE (1971) selecionou sublinha gem para alta e baixa eficiência fotossintētica, de linhagens elites. Pelo que se pode observar, do ponto de vista genético, é perfeitamente possível a obtenção de germoplasmas com alto potencial de fotossintese.

Uma planta com a1ta eficiência fotossintética não é necessariamente uma planta eficiente para conversão de grãos. Segundo MOCK e PEARCE (1975) é necessário que ela tambēm tenha alta capacidade de produção dos fotossintetizados em grãos. Uma planta de porte baixo, por exemplo, poderia per der menos material assimilado nos processos de respiração, uma vez que uma planta maior com maior superfície de caule, órgão não fotossintetizante, poderá respirar mais. Também neste tipo de planta deve haver maior economia no processo de trans1ocação, alēm de uma menor dominância apical, com resultados mais positivos para a produção. 


\subsection{Caracteristicas Foliares}

\subsubsection{Desenvolvimento das Folhas e sua Função}

As folhas estão intimamente relacionadas com a formação e o desenvolvimento delas prōprias e dos outros' órgãos da planta, o que as tornam um dos elementos mais importantes da planta.

o número total de folhas que uma planta vai ter, é definido em fases bem iniciais do desenvolvimento. STEIN(1955) trabalhando com linhagens normais e braquíticas observou que na própria semente, o embrião jä possui em torno de 5 a 6 foThas definidas e que na fase de plântula praticamente define-se o nümero total de folhas da planta. o autor observou que com 27 dias do plantio a fase de formação de folhas tinha se completado com uma média de 14 folhas totais. Este número pode variar muito com os genótipos, e com o ambiente. CHASE et alii (1967) avaliaram 21 híbridos, e encontraram uma variação de 16,2 a 18,3 folhas totais por planta para ambientes diferentes. A variação entre plantas dentro de um mesmo hỉbrido, numa parcela, foi observada por HANWAY (1963) entre valores de 15 a 22 embora a maioria dạs plantas exibissem 18 a 20 folhas totais. Tambëm ALDRICH et alii (1975) consideraram que o milho normal do "Corn" Belt" possui em torno de 20 a 23 folhas e que estas prati camente se encontram formadas,em torno de 30 dias do plantio. Segundo 
estes mesmos autores e HANHAY (1963), em torno de 5 a 7 foIhas inferiores da planta morrem antes mesmo que as superiores completem seu desenvolvimento. Desta forma, o número de foThas ativas na planta por ocasião do florescimento e período de enchimento de grão é menor e de acordo com EASTIN(1969), em função de suas observações em dois híbridos, este númeró situa-se em torno de 13 folhas. Em milhos precoces ROOD e MAJOR (1981) observaram em um đialélico, uma variação de 10 a 13 fo 1has por ocasião do florescimento. Os milhos usualmente culti vado no Brasil, segundo informação pessoal do Dr. Paterniani, apresentam um número final de folhas ativas em torno de 17. Ainda a este respeito tem-se observado uma correlação muito es treita entre número de folhas e dias para o florescimento, : o que significa dizer, que seleção para precocidade pode levar a uma diminuição do nümero de folhas (CHASE et alii, 1967; ROOD e MAJOR, 1981).

o desenvolvimento em peso seco das folhas é len to a princípio, porém por volta dos 35 a 40 dias do plantio inicia-se uma fase linear de rápido crescimento. Segundo HANWAY (1962) num período de 15 dias as folhas passam de $30 \%$ a $85 \%$ do seu peso final, constituindo-se este um período crítico para a formação da área foliar ativa da planta. 0 peso seco final das folnas é atingido alguns dias antes do florescimento e a área foliar máxima é atingida pela folha quando ainda envolta pelas folhas mais velhas, não mais se desenvolvendo em compri 
mento ou largura após estar completamente exposta. Esta fase de räpido desenvolvimento foliar acompanha aproximadamente o período de rápido crescimento em altura pela planta. Segundo ALDRICH et ali $i$ (1975) a aproximadamente uma semana da liberação do pólen todos os internódios, à exceção dos 2 a 3 superiores, já se alongaram ao máximo, sendo a altura final da plạn ta obtida quando os seus internódios apicais se desenvolvem e deixam o pendão proeminentemente alto e em condição de liberar o pólen.

0 aproveitamento dos produtos fotossintetizados pelas folhas obedece a modelos definidos de consumo. Segundo revisão a este respeito apresentada por MAGALHÃES e SILVA(1978) as folhas novas em desenvolvimento importam substâncias de outros órgãos para a garantia de seu crescimento e tão logo se tornem autosuficientes, passam a contribuir para outros órgãos. Durante a fase vegetativa, as regiões de crescimento da planta mobilizam os fotossintetizados para seu desenvolvimento. Porém com a formação dos órgãos reprodutivos estes também passam gradativamente a importar os assimilados, transformando-se em sítios de intenso consumo, quando em $\dot{f} a s e$ de rá pido desenvolvimento. EASTIN (1969) estudou a distribuição de carbono marcado oferecido a diferentes folhas da planta,ten do obseṛvado uma relação específica entre a posição e função da folha. Por ocasião do embonecamento, as folhas superiores forneceram carbono marcado para o pendão, parte superior do 
caule e espigas, sendo que apenas uma pequena fração do mesmo foi para as partes inferiores. Na medida em que as folhas se aproximam da espiga, há uma forte polarização por parte desta ūitima, com distribuição de carbono tambēm para a parte mediana do caule. Quando o tratamento foi feito na segunda fo1ha abaixo da espiga, a predominância foi de distribuição do carbono para a raiz e base do colmo, além de uma pequena fração também para a espiga. Quando as observações foram feitas 20 dias após o embonecamento, ocasião em que a parte superior do caule, pendão e folhas cessaram o desenvolvimento, estando a espiga, por outro lado, em fase de crescimento acelerado, as diferenças na distribuição do carbono em função da posição da folha foi ainda mais óbvia. Todas as folhas acima da espi ga contribuiram quase exclusivamente com carbono para a espiga, enquanto que aquelas abaixo, para a parte basal do caule, raízes e ainda numa grande proporção também para a espiga. 0 autor observou que além do estádio de desenvolvimento, genótipos diferentes podem afetar a relação entre a posição da folha e a distribuição de assimilados.

'2.5.2. Intercepção da Luz Solar

$\because \quad$ A produção de uma planta depende primariamente da sua capacidade dè interceptar a luz solar e em segundo 1 u- 
gar de sua potencialidade intrínseca de transformar a energia irradiante em energia química e de armazenā-1a nos órgãos especiais de reserva. A 1 uz não interceptada pela folha é perdi da e eventualmente pode causar problemas adicionais à cultura pois ao alcançar o solo promove perdas de água por evaporação e ainda estimula o nascimento e desenvolvimento de plantas daninhas.

A planta de milho tem um crescimento inicial len to. Entretanto, por volta dos 40 dias do plantio inicia-se um desenvolvimento acelerado atingindo o seu máximo de área foliar por ocasião da floração, em torno de 30 dias após. Para se medir a ärea de folhas de uma plantação tem-se usado o "Indice de Area Foliar" (IAF), o qual é uma relação entre a ārea de fo 1 ha da cultura e a área de solo por ela ocupada. Este índice tem muita importância pois dá uma indicação da área das folhas que num determinado momento pode estar interceptando a 1 uz solar, em relação ao espaço por ela ocupado. Tendo em vista o modelo de desenvolvimento das plantas, no princípio o IAF da cultura é baixo, quando uma grande parte da radiação incidente é perdida no solo. Posteriormente passa por uma fase de crescimento linear, atingindo o máximo por ocasião do florescimento da planta, conforme observações de Allison citado por TOLLENAAR (1977). Também citado por este autor Vietor e Musgrave observaram um declínio no IAF na fase final do período de enchimento do grão. Este declínio é função de fatores do ambiente que 
reduzem a ärea foliar das plantas (pragas, doenças, temperatura, etc.) e da própria senescência natural das mesmas. 0 IAF entretanto não depende somente do padrão de crescimento exibido pelas plantas, mas tambëm de outros fatores como densidade de plantio e estado nutricional (EVANS e WARDLAW,1976). O efei to da aplicação de nutrientes foi estudado por EIK e HANWAY (1965) tendo sido positivo sobre o número, ārea e duração das folhas bem como sobre a velocidade de aparecimento das mesmas durante o crescimento. O efeito da densidade de plantio sobre o IAF tem sido observado por vários autores. Na medida em que se aumenta o número de plantas a área foliar de cada planta da população é diminuída, embora em proporção menor em relação ao acréscimo devido ao maior número de plantas, o que resulta em aumento do IAF. NUNEZ e KAMPRATH (1969), obtiveram acréscimo no IAF de 2,5 para 4,5 com populações de 34.500 e 69.000 plantas por hectare, respectivamente.

0 IAF ideal para uma cultivar será aquele que resultar em maior produtividade, entretanto pode variar para cada genótipo e com as condições ambientais. Em trabalho reali zado por SCARSBROOK e DOSS (1973) em Alabama, utilizando dois hỉbridos e espaçamentos e densidades de plantio diferentes para gerar ampla variação no IAF, conseguiram observar que a re1 ação entre produção e IAF obedeceu a uma distribuição que se ajustou melhor a uma equação quadrática e que a produção de grãos como variável dependente teve seu valor maior com o IAF 
em torno de 3,5: Este ótimo foi também encontrado por NUNEZ e KAMPRATH (1969) além do qual a produção mostrou tendência de diminuição. EIK e HANWAY (1966) encontraram uma tendência 1inear da produção apenas até o IAF de 3,5. Também HOYT e BRADFIELD (1962), em Nova Iorque, notaram uma tendência seme1hante para a taxa de assimilação, a qual teve seu ótimo para um IAF em torno de 2,7, porém usando metodologia diferente, através da qual os diversos IAF foram obtidos por desfolha de plantas de uma plantação. Segundo estes autores seus dados indicam que a queda da taxa de assimilação após um ótimo de IAF foi função do sombreamento das folhas inferiores, as quais, por este motivo, foram levadas a uma baixa eficiência fotossin tética. Encontraram que a produção de matéria seca produzida com um IAF de 3,3, sofreu uma redução acentuada das folhas superiores para os inferiores, sendo quatro vezes maior nas primeiras. A intensidade luminosa medida sofreu uma redução de aproximadamente $80 \%$ da região do ponteiro para a parte basal da planta. A queda da eficiência das folhas em função da sua posição mais baixa foi também observada por ALLISON e WATSON (1966), os quais verificaram serem as folhas superiores,médias e inferiores responsäveis por $40 ; 35$ a 40 e 5 a 25 por cento da matéria seca produzida após o florescimento, respectivamente.

Quando a cultura de milho encontra-se em fase inicial de crescimento, praticamente não há competição por luz entre as plantas, e todas as folhas a recebem abundantemente. 
Nestas circunstâncias o IAF é muito baixo, sendo ele o fator mais limitante à produção de matéria seca. Com o desenvolvimento da cultura, o problema do sombreamento mútuo entre plantas, e entre folhas da mesma planta acentua-se, atingindo um má ximo por ocasião do máximo de IAF que ocorre em torno do florescimento. Nesta fase, para plantas do grupo $\mathrm{C}_{3}$ como,o arroz, por exemplo, segundo NORCIO e PANTASTICO (1973), as fo1has superiores, recebem muito mais luz do que a necessária para a sua capacidade de sintese e, outras, as inferiores, recebem muito pouca luz, até mesmo aquem da necessária à compensação entre a síntese e a perda por respiração. Em milho, embora as folhas superiores não se saturem, mesmo nas horas de maior intensidade luminosa, elas entretanto sintetizarão com menor eficiência (EASTIN, 1969). Por outro, 1ado, as folhas in feriores, como demostrado, produzirão muito menor quantidade de matéria seca em função do sombreamento. Uma vez atingido o ótimo de IAF, este deixa de ser o fator limitante, passando a sê-1o a iluminação das folhas.

A maior limitação à obtenção de altas produções segundo LOOMIS e WILLIAMS (1963), é o.tempo requerido para as plantas atingirem o ótimo de IAF, pois até que tal ocorra muita 1 uz é perdida no solo, não sendo interceptada pela planta. Uma maneira que tem sido usada para contornar o problema é aumentar-se a dénsidade de plantio. Entretanto se esta é uma alternativa favorável na fase jovem da cultura, pode não o 
ser quando esta alcança seu mäximo ém desenvolvimento, em função do efeito negativo do sombreamento de folhas, de elevada proporção de plantas estéreis e do aumento do acamamento. Isto implica em dizer que uma densidade de plantio que promova um ótimo de IAF resultará sempre em perdas substânciais de luz nas fases mais jovens da cultura, o que por outro lado somente po.deria ser atenuado através de uma distribuição mais eficiente de plantas ou com a obtenção de plantas mais tolerantes a altas densidades de plantic (resistência ao sombreamento, folhas eretas, plantas baixas, etc.).

Mesmo quando à cultura atinge seu ótimo em IAF, uma certa proporção da $1 u z$ é perdida no solo. DENMEAD et ali $i$. (1962) observaram numa cultura de milho com plantio em covas de quatro plantas, espaçadas de aproximadamente 1,0 m,após seu máximo em IAF, que a intercepção da luz pelas folhas foi de $75 \%$ da irradiação tota 1 , sendo $73 \%$ captada apenas por aquelas acima da parte mediana da planta e $25 \%$ perdendo-se no solo. Estes autores consideraram por outro lado, que uma distribuição melhor das plantas poderia diminuir as perdas. Segundo DUNCAN (1972) a melhor maneira de disposição das plantas para maior intercepção de 1 uz solar é a equidistante e, nestas circunstâncias com IAF calculado igual a 3 , em torno de $10 \%$ de luz incidente não é retida pelas folhas, alcançando o solo. Entre tanto, como nas condições normais de cultivo o espaçamento das plantas é de 1,0 m entre linhas, e $20 \mathrm{~cm}$ entre plantas, e ain- 
da, porque na prätica, nem sempre sé consegue obter IAF satisfatōrio, é possível que a perda de luz seja maior.

A luz que alcança o solo, além de não ser aproveitada, trás, como jā foi dito, problemas adicionais à cultura, como maior incidência de plantas daninhas e perda de água por evaporação. TANNER et ali $i$ (1960) consideraram que $80 \%$ da energia disponível para a evaporação da água do solo é proveniente da radiação solar direta, que penetra através da folhagem da planta e apenas $20 \%$ da radiação indireta. Segundo estes autores numa população de 54.000 plantas por hectare, com as plantas inteiramente deseńvolvidas, a evaporação pode repre sentar cerca de 25 a $35 \%$ da água total evapotranspirada. Consi. derando-se ainda o ciclo todo da planta, esta proporção deve ser muito maior pois a incidência direta da luz no solo nas fa ses jovens da cultura também o é. YAO e SHAW (1964) avaliaram a eficiência do uso da água em densidade de 35.000 a 70.000 plantas por hectare e chegaram à conclusão de que no espaçamento mais fechado, o uso da água foi menor e mais eficiente e, que o aumento da densidade de plantio aumentou o consumo de $\bar{a}-$ gua, porém numa proporção menor relativa ao número de plantas.

Outro aspecto muito importante relativo a intercepção da luz solar se refere a período no qual as folhas permanecem ativas. CROSBIE e MOCK (1981) avaliaram três populações melhoradas de milho e encontraram que pelo menos uma de 
las teve na maior duração do período ativo das folhas, uma das principais causas do aumento da produtividade. 0 retardamento do iníciolda senescência das folhas aumenta a duração do perío do de intercepção da irradiação solar e consequentemente aumen ta a produção de matēria seca que pode ser convertida em grãos.

\subsubsection{Arquitetura Foliar}

Tem sido geralmente aceito entre os pesquisadores que uma das maiores 1 imitações ao aumento da produtividade potencial do milho se refere à sua capacidade de utilização da 1 uz solar.

Conforme já foi considerado anteriormente, a pro dução do milho aumenta linearmente com o IAF, como resultado de uma maior intercepção de luz. Entretanto, a partir de determinado limite, a resposta è alterada, tornando-se até mesmo negativa. DUNCAN (1971) e 1972) através de observações teóricas considerou haver uma fase.linear entre a produção è a densidade de plantio, a qual é seguida por outra em que a produção por planta cai com o aumento da população,elevando-se, entretanto, a produção por ārea até um limite por volta de um IAF em torno de quatro,ạlém do qual ela também cai. 0 aumento da densidade de plantio além do valor ótimo de IAF, na expectativa de aumentar-se a in tercepção da luz solar, traz värios problemas para a cultura destacan 
do-se o aumento na frequência de plantas estéreis, como um dos mais importantes fatores para a redução da produção (LAMBERT, 1971; BUREN et alii, 1974; LAMBERT e TOMNSON, 1978). Este fato tem sido demonstrado ser associado ao aumento do sombreamento de folhas. (EARLEY et alii, 1966) e portanto plantas tolerantes ao sombreamento ou que permitam maior penetração de 1 uz têm me nor frequência de plantas estẹreis (STINSON e MOSS,1960; WILLIAMS et alii, 1965; PENDLETON; 1968; LAMBERT, 1971; DUNCAN, 1972 e LAMBERT e JOHNSON, 1978). BUREN et alii (1974) avaliaram vários hỉbridos simples em densidades de até 98.000 plantas por ha, durante três anos, concluindo que as seguintes características indicam tolerância a plantios mais densos: coincidência do florescimento masculino e feminino, emissão rápida da primeira espiga, pendão menor, prolificidade e ainda produção efí ciente por ärea foliar.

Outro problema que cresce com o aumento da densidade de plantio é o acamamento de plantas,o qual eventualmente pode ser até mesmo mais 1 imitante que as plantas estéreis (TOLLENAAR, 1977). Neste caso também,plantas que permitem maior penetração da luz solar podem amenizar o problema. ARIYANAYAGAM et alii (1974) obtiveram uma população de plan- tas de folhas eretas que apresentaram maior resistência ao aca mamento. 0 porte baixo das plantas tem sido também considera da como fator importante de resistência ao acamanto e de to- 
lerância a plantios mais densos (GALVÃo e PATERNIANI, 1974; RISSI et alii, 1976). Outros problemas relacionados com densidades altas de plantas tem ainda sido relatados, como diminuição do período de enchimento de grãos, menor peso e número de sementes, menor número de folhas e ärea foliar da planta, menor produção por planta individual (EIF e HAWAY, 1965; LAMBERT .e JOHNSON, 1978). O mútuo sombreamento de folhas é uma consequência importante do aumento da densidade de plantio, e que influi na eficiência de sintese da planta. STINSon e MOSS(1960) entretanto chamaram a atẹnção para as diferentes respostas do milho às variações na densidade de plantio, èm função das inté rações do genótipo. Este autor observou que híbridos classifi cados como mais ou menos tolerantes a altas densidades, manti= veram o mesmo desempenho quando submetidos a sombreamento arti. ficial. A obtenção por seleção, de populações tolerantes a a 1 tas densidades foi citada por LAMBERT (1971) com um meio de se atender à tendência de seu aumento visando melhor aproveitamen to da luz solar.

Do ponto de vista da arquitetura foliar, plantas de folhas mais eretas têm sido sugeridas como um dos meios de aumentar-se a eficiência das gramineas no aproveitamento da energia solar. Em arroz, por exemplo, värios trabalhos têm de monstrado a superioridade, acentuada, dos tipos modernos de plantas caracterizadas principalmente pelas suas folhas eretas 
e porte baixo (DATTA et alii, 1968; SAINI, 1976; PARIS, 1980), os quais têm aumentado a produtividade de arroz em muitas regiões do mundo. Também em outras culturas tem sido demonstrado um efeito positivo das folhas mais eretas, como em trigo e centeio, conforme revisão bastante completa apresentada por TRENBATH e ANGUS (1975) a respeito de inclinação de folhas.

Em milho, conforme jā discutido previamente, a produção de matéria seca por planta não cresce linearmente com a intensidade luminosa, haja visto que com aproximadamente $50 \%$ da luminosidade máxima a planta pode atingir em torno de $80 \%$ dá fotossíntese máxima, e acréscimos de luminosidade não resul tarão em produção proporcional de matéria seca (MOCK e PEARCE, 1975). Isto significa que em luminosidade alta a folha é pouco eficiente na utilização da luz solar. Nestas circunstâncias, o ideat seria que mais folhas da planta estivessem recebendo luz, porém em níveis menores que os recebidos pelas fo1has superiores. Com as plantas tradicionais, ao aumentar-se o IAF, aumenta-se a intercepção da luz solar,sendo que apenas as folhas superiores recebem a luz, ficando as inferiores sombreadas, tanto mais quanto maior o IAF. As folhas mais eretas, por outro lado, permitem um aumento da área foliar da cultura sem os agravantes do sombreamento de folhas, promovendo uma me Thor distribuição da radiação solar para um maior nümero de fo 1has, o que é teoricamente favorável para a obtenção de maio res produtividades (DUNCAN, 1972). 
Outro aspecto que vale a pena ressaltar,se refe re ao fato de que a densidade de plantio é função do IAF máximo ideal da plantação, obtido por ocasião do florescimento quan do a competição entre plantas por luz também é máxima. Como já - foi visto nesta revisão, densidades de plantio acima ou abaixo da faixa ideal resultam em queda da produção. Disto resulta que nas fases jovens da cultura, haverá abundância de luz para cada planta e perda de um grande excedente, não interceptado pelas folhas das plantas ainda pequenas. Aquelas de folhas eretas, entretanto, por terem a característica de suportarem um ótimo de IAF máximo em níveis bem maiores, podem por consequên - cia, serem plantadas também em densidades mais elevadas. Com isto, um maior nümero de plantas vai se beneficiar da abundân cia da luz nas fases mais jovens sem que resulte em problemas de sombreamento na fase adulta, como ocorre nas tradicionais, graças à maior distribuição da luz solar entre suas folhas.

o aumento da população de plantas, segundo PENDLETON (1968) resultará em consumo um pouco maior de água ou nutrientes, mas por outro lado terá substancialmente aumentada a capacidade da exploração do ambiente luminoso. As folhas ere tas, como já foi dito, permitem também um nível de luminosidade maior em todos os extratos da copa da planta e apesar de nas plantas tradicionais as folhas inferiores contribuirem relativamente pouco para a produção total de matēria seca, de 
acordo com MOSS e PEASLEE (1965), elias guardam,por outro 1ado, quase o mesmo potencial de sintese que as do ponteiro, desde que adequadamente supridas de àgua nutrientes e mesma intensidade de 1uz. As folhas eretas têm a vantagem de explorar também um pouco mais este potencial. Moss (1964) demonstrou que as folhas de mitho fotossintetizam igualmente tanto na sua superficie superior quanto na inferior,desde que sob a mesma intensidade de 1 uz e portanto as folhas.eretas por exporem mais sua face dorsal à 1 uz, não são prejudiciais por isto.

Segundó DONALD (1968) plantas fortemente competidoras, como são as variedades tropicais de milho, podem não ser as mais interessantes para produção em comunidades homogêneas, pelo gasto adicional de energia no processo de competição, o que não ocorre com as de folhas eretas que são menos com petidoras.

A despeito das considerações teóricas que têm mostrado uma grande possibilidade de se aumentar a produção da cultura do milho via folhas eretas,os resultados de pesqui sa a respeito têm sido conflitantes e pouco conclusivos, apesar de um número relativamente grande de trabalhos já realiza dos (EVANS e WARDLAW, 1976).

$\therefore \quad$ Um dos primeiros trabalhos publicados a respeito do comportamentoide plantas com folhas eretas em milho, em condições de campo, foi realizado por PENDLETON et alii (1968). 
Os autores avaliaram o efeito de folhas eretas através de um híbrido c103 x Hy) em duas formas isogênicas para o carāter "Zigulezess-2". $\left(\lg _{2}\right)$ : Os genōtipos normais apresentavam foThas horizontais e pendões ramificados, enquanto que os tipos "Ziguleless" apresentavam folhas eretas e pendões menos ramificados. 0 trabalho foi desenvolvido numa população de $\quad 59.30,4$ plantas/ha no espaçamento de $50 \mathrm{~cm}$ entre linhas e na linha, uma planta a cada $33 \mathrm{~cm}$. Para um IAF similar,em torno de quatro, os autores observaram uma produção $41 \%$ maior para a forma de folhas espetadas. As produções foram associadas à percentagem de plantas estéreis nas populações, sendo-maiores na forma de folhas normais. 0 híbrido estudado segundo os autores, foi con siderado de pouca tolerância ao sombreamento,e por este fato o de folhas espetadas, com maior distribuị̧äó de luz, produziu mais. De acordo com TRENBATH e ANGUS (1975) o híbrido sensível ao sombreamento usado no trabalho não representa a média das cultivares de milho e portanto os resultados de Pendleton e colaboradores superestimaram o efeito de folhas eretas.

PENDLETON et alii (1968) desenvolveram tambēm um outro trabalho, no qual orientaram artificialmente as foIhas das plantas, por meio de fitas de polietileno transparen tes, tornando-as todas eretas ou alternativamente apenas aquelas acima da espiga. Utilizaram um hỉbrido comercial e as mesmas condições de $\dot{p} 1$ antio do ensaio anteriormente relatado. os tra- 
tamentos com as folhas eretas ( $20 \%$ do vertical) e, apenas com as superiores eretas, produziram respectivamente, em torno de $7 \%$ a $14 \%$ mais do que as plantas normais. Estes resultados levaram PENDLETON (1968) a recomendar como planta.ideal aquela que tivesse as folhas superiores eretas e as inferiores na posição normal. Estas aproveitariam a 1 uz não interceptada pelas supe riores e exerceriam um efeito de competição com as plantas daninhas, graças a um maior sombreamento do solo. A este respei to, TRENBATH e ANGUS (1975) consideraram, em sua revisão,que a configuração da planta que,pelos estudos de predição, teoricamente deveria maximixar a produção, varia com o IAF. Para valo res moderados do mesmo, o ideal seria plantas com as folhas eretas as quais se tornariam progressivamente mais horizontais na medida que se situassem mais baixo na planta. Com valores de IAF maiores ou menores, o ideal seriam as folhas disporem-se cada vez mais eretas ou mais horizontais, respectivamente. Outros trabalhos com folhas verticais por manipulação artificial têm mostrado um efeito positivo na produção. WINTER e OHLROGGE (1973) observaram que nas baixas densidades de plantio,as plan tas com folhas normais foram mais produtivas, porém em altas densidades, as plantas com as folhas mantidas verticais superaram as normais. Em condições ótimas para as duas categorias, as plantas com folhas verticais produziram mais, embora as di-.... ferençä́ não tenham sido significativas. KATTA e GIL (1970) também por meio de manipulação das folhas observaram uma produ 
ção em torno de $8 \%$ a mais para as eretas, em uma população de plantas baixas.

Outros trabalhos de natureza: genética têm também concordado com as observações de Pendleton. LAMBERT(1971) por exemplo avaliaram värios híbridos isogênicos para a condi ção de folhas normais ( 30 a $40^{\circ}$ com a vertical) e eretas, nas formas "ZiguleZess - 1 " ( 6 a $10^{\circ}$ com a vertica1) e "Ziguleless-2" (8 a $11^{\circ}$ com a vertica 1$)$. Dois destes hỉbridos que melhor res ponderam às folhas eretas, foram avaliados nos espaçamentos de $50 \mathrm{~cm}$ entre 1 inhas e nas densidades de 45.000 a 90.000 plantas/ha. A forma "liguleless-2" na sua melhor densidade 75.000 plantas/ha) produziu em média $7 \%$ a mais que a forma normal tam bém na sua densidade ótima (60.000 plantas/ha). Resultados de mais três anos de avaliação dos materiais foram apresentados por LAMBERT e JOHNSON (1978). As densidades ótimas permanece ram as mesmas e a diferença em favor da ereta diminuiu para 4,3\%. Estes mesmos autores em três outros hỉbridos, nas mesmas três formas isogênicas, observaram que a forma "liguleless-2". foi superior à normal em produção em $9,7 \%$ e $48,9 \%$, nas densidades de $78.457(50 \mathrm{~cm} \times 25 \mathrm{~cm})$ e $156.915(50 \mathrm{~cm} \times 13 \mathrm{~cm}) \mathrm{p} 1 \mathrm{an}$ tas/ha,respectivamente. A forma "Zigulezess 1 " em nenhum caso sobressaiu em relação à forma normal. Dos seus dados os auto res concluiram que os tipos de folhas eretas requerem maior den sidade de plantio que os tipos normais para um ótimo de produtividade. 
Outros resultados não'têm demonstrado

vantagens para as formas eretas. No trabalho de LAMBERT (1971) de v vários hỉbridos, todos nas formas isogênicas normal, $1 \mathrm{gl}_{\mathrm{l}}$ e $1 \mathrm{~g}_{2}$, quatro deles, avaliados numa população de aproximadamente 80.000 plantas/ha, em dois espaçamentos ( $51 \mathrm{~cm}$ e $76 \mathrm{~cm}$ ) comportaram-se diferentemente. No espaçamento mais fechado as produ ções foram menores de modo geral e as formas eretas nos dois espaçamentos tenderam a diminuir a produção em dois híbridos e a mantê-1a em dois outros.

Também RUŚSEL (1972) e HICKS e STUCKER (1972) tra balhàram com materiais de foihas eretas em várias densidades de plantio,porém não encontraram vantagens para as mesmas. Efeitos negativos para a produção foram obtidos. por PozAR (1981), o qual avaliou folhas eretas com e sem lígula em relação à testemunha normal, em vários espaçamentos entre linhas, e número constante de plantas na linha. As plantas de folhas normais, no espaçamento de mäxima produção superaram as erețas, em torno de $20 \%$. ARIYANAYAGAM et a $i$ i. (1974), desenvolveram um. programa de seleção fenotipica bidirecional em uma população, obtendo populações de folhas eretas $\left( \pm 25^{\circ}\right.$ com a vertical) e mais flácidas ( 50 a $54^{\circ}$ com a vertica 1$)$. Estas populações fo. ram avaliadas em densidades de 40.000 a 80.000 plantas/ha, não tendo sido observadas diferenças em produção entre elas. Estes autores observaram que folhas com diferentes ângulos em relação a caule podem ser obtidas com certa facilidade dada a a 1- 
ta herdabilidade observada para o caráter. A este respeito SILVA et alii (1976), sugeriram melhoramento poligênico dado uma série de..problemas causados pelo gene $1 g_{2}$.

Em função da não concordância dos resultados obtidos pelos diferentes autores, MOCK e PEARCE (1975), levantaram diversos pontos que segundo eles estariam influindo nos resultados. Os genótipos usados nestes estudos nem sempre pos suiam o tipo desejado de folha eretas mas, por exemplo, os āpices pendentes causando sombreamento das folhas inferiores. A densidade de plantio nem sempre foi o ótimo para a manifesta ção da capacidade das eretas: A diferença de ângulo entre as eretas e normais em alguns casos foi muito pequena para provocar mudanças detectáveis na produção. Segundo. SILVA et alii (1976), a maneira de se medir o ângulo foliar pode levar a erros de interpretação, haja visto que plantas de folhas eretas e normais podem ter o mesmo ângulo na base da folha em relação ao caule, sendo que as primeiras mantêm-se eretas em todo o seu comprimento, enquanto as ültimas sãoflácidas. TREMBATH ANGUS (1975) chamam a atenção para a variação dos genótipos quanto à tolerância ao sombreamento.

$$
\text { Outro fator limitante e que está associado }
$$
genótipo se refere à capacidade de estocagem dos produtos fotossintétizados, a qual sendo limitante de nada resolveria meihorar a eficiência da fonte (ARIYANAYAGAN et alii, 1974). 
Outro aspecto que vale a pena ser lembrado é que a introdução de um gene, como o $1 g_{2}$, o qual provoca uma mudança acentuada na fisionomia da planta, dificilmente encontrará uma condição de harmonia num genótipo selecionado durante muito tempo sem sua presença e por consequência é de se esperar que a falta de equilíbrio entre os caracteres da planta resultem em queda da performance da mesma.

\subsection{Prolificidade}

A planta de milho apresenta um potencial ineren te de prolificidade de espigas, conforme SASS e LOEFFEL (1959) demonstraram ao observarem que vārias ramificações laterais axilares sofrem diferenciaçãofloral, muito embora, em geral apenas uma delas (a superior), se desenvolva com produção de grãos. O termo prolificidade, neste trabalho, será usado para referir-se às plantas com mais de uma espiga por colmo. Segundo HALLAUER e TROYER (1972) a ausência de prolificidade dos mi 1hos atuais é consequência de pressão de seleção exercída pelo homem, durante um longo período, no sentido de se ter espigas maiores. Entre os milhos mais primitivos haviam muitos que produziam várias espigas por planta (BROWN, 1965), tanto em fun ção do perfilhamento do colmo como do maior número de espigas em cada um. 
Os milhos considerados não prolíficos podem,entretanto,apresentarem-se como tal, em condições especiais de disponibịlidade de água e nutrientes e-sob baixas densidades de plantio. Segundo TSOTSIS (1972) as folhas inferiores da planta é que suprem a formação da segunda espiga,e para tanto é necessário que as mesmas estejam suficientemente iluminadas. para que quantidades de matéria seca adequadas sejam fornecidas. Isto normalmente oeorre sob baixa densidade populacional, pois o conträrio levaria ao mútuo sombreamento das folhas com acentuada perda de eficiência das inferiores. os tipos prolíficos, por outro lado, mantém esta sua característica mesmo em densidades relativamente maiores pois, segundo o referido autor, desenvolvem um mecanismo que permite um suprimento similar de nutrientes para ambas as espigas.

Mesmo nos tipos prolíficos, a espiga superior é geralmente maior que a inferior, o que, segundo PATERNIANI (1981) é função de um efeito de dominância apical presente na planta de milho, em face da qual as partes superiores da planta têm prioridade pelos fotossintetizados. Desta forma, não somente o efeito da posição relativa da fonte e depósito influi na alo cação dos fotossintetizados,mas também a dominância apical, a qual segundo ANDERSON (1967) é determinada por um balanço hormonal entre as partes que demandam pelos assimilados. Plantas com acentuada dominậncia apical podem ter até o dobro de áci- 
do indol acético (AIA) no pendão. Plantas macho estéreis têm cerca da metade do teor de AIA que a respectiva versão normal. os milhos prolíficos tem também menor teor de AIA, sendo consi derados como de menor dominância apical (HALlAUER e TROYER,1972). Dada esta relação observada,quanto menos prolífico o material, maior a dominância apical, sendo possível que a seleção de plạn tas com uma espiga tenha acentuado o efeito desta dominância (ANDERSON, 1967 ; PATERNIANI, 1981).

A produção de uma planta está sujeita a vários fatores, os quais não sendo fornecidos adequadamente podem pro vocar uma redução em seu désempenho. Segundo BRown (1965) a reação da planta a agentes estressantes, vai depender de sua intensidade, podendo resultar na redução do número de fileiras de grãos da espiga, abortamento dos grãos do seu ápice e ainda em casos de estresse muito intenso, no não desenvolvimento de espigas com sementes. Especialmente em função da tendência de se plantar mais densamente,um dos principais problemas, como já foi discutido, é o aparecimento de frequências altas de plan-. tas estéreis. A forte competição por água, luz e nutrientes, que se estabelece nas altas densidades leva a planta a formar preferencialmente o pendão, e se possível a espiga, em função de dominância apical (PATERNIANI, 1981). Os milhos prolificos segundo.Josephson, citado por Collins et alii (1965) suportam melhor as variações de umidade e fertilidade e também as varia 
ções na densidade de plantio,pois são mais capazes de se ajustarem ao ambiente pela possibilidade de produzirem maior ou me nor número de espigas por planta. Resultados semelhantes foram obtidos por Collins et alii (1965), com os tipos prolificos sen do superiores nas menores e maiores densidades de plantio. RUS SEL (1968) por outro lado observou esta superioridade apenas nas densidades mais altas.

Uma revisão pormenorizada sobre os trabalhos relativos à prolificidade em milho foi apresentada por HALLAUER e TROYER (1972) e em resumo os autores concluiram que em todos eles os tipos prolificos mostraram maior flexibilidade para se ajustarem às condições de estresse, através de uma menor interação genótipo e ambiente. Nas condições de baixa densidade de plantio produzem em média mais de uma espiga por planta e nas altas densidades as plantas estēreis não são um fator tão importante 1 imitando a produção. Os tipos não prolificos em condições de alta densidade de plantio, mostraram tendência de aumento da frequência de plantas estéreis, com: comprometimento da produção e, nas baixas densidades podem não produzir número suficiente de espigas para compensar o menor número de plan tas.

o aumento da produção e sua maior estabilidade são doi objetivos importantes que se tem conseguido com a seleção para o aumento da prolificidade das plantas. HALLAUER e 
TROYER (1972) citaram um trabalho dé Lonnquịst, no qual o autor obteve ganhos médios de $6,28 \%$ na produção por ciclo de se- leção massal para prolificidade na população "Hays Golden". Tam bém apresentaram resultados de Hallauer em que de 14 híbridos simples obtidos de material prolífico,sete foram significativa mente mais produtivos do que a melhor testemunha dentre as seis utilizadas (hỉbridos de linhagens elites). Também paternIANI (1980) desenvolveu um esquema de seleção massal em ambos os se xos para prolificidade er: duas populações de milho,tendo obtido em três ciclos de seleção, ganhos de 3,9\% e 17,6\% em prolificidade e $5,7 \%$ e $18,9 \%$ em pṛodução, para as duas populações respectivamente. o ganho genético por seleção através de métodos tão simples como seleção massal, demonstram que é relativa mente fácil a obtenção de materiais prolíficos. DUVICK (1974) conseguiu por retrocruzamento e seleção transferir nem cèto. grau a prolificidade do milho pipoca para o milho comum, conse guindo nos tipos obtidos, produtividade tão alta e até mais elevada que as formas originais. SouZA Jr. et alii (1981) obser varam na população "Suwan" uma herdabilidade no sentido restrí to em torno de $40 \%$ e ainda uma correlação entre prolificidade e produção da ordem de 0,94 .

Um problema que tem sido observado nos tipos pro Iíficos.ē o seu maior acamamento (DUVICK, 1974). Entretanto se gundo HALLAUER e TROYER (1972) o problema também ocorria nos 
tipos não prolíficos e por seleção éste defẹto pode ser corri ǵido.

\subsection{Influẽncia do Pendão na Produtividade}

O tamanho do pendão é outra característica bas tante estudada e que tem'demonstrado estar relacionada com a eficiência na produção de grãos. Vários trabalhos têm demonstrado que a redução do tamanho do pendão,sua remoção, ou ester $\underline{i}$ lidade têm resultado em diminuição da frequência de plantas sem espigas, além do efeito de seu sombreamento, resultando no au-. mento da produção das plantas, especialmente quando sob condições desfavoráveis de água, nutrientes e mesmo fórte competição entre indivíduos em densidades de plantio acima do normal.

Em revisão apresentada por GROGAN (1956) foram citados alguns trabalhos do século passado que jā demonstravam a superioridade produtiva das plantas despendoadas. Este autor,trabalhando com dois híbridos e três variedades, observou que a produção das plantas despendoadas foi maior em condi ções de deficiência de àgua, baixa fertilidade e plantios mais densos. Entretanto em condições não limitantes e de alta produtividạde o seu efeito não foi notado. 0 s ganhos em produção foram consequência de menor nümero de plantas estéreis,espigas maiores e maior prolificidade para os tipos prolíficos 
avaliados. Segundo ainda o mesmo autor, o comportamento inferior das plantas com pendão pode ter uma explicação razoável, uma vez que o pendão desenvolvendo-se primeiro que a espiga demanda para si os assimilados disponíveis. Por outro lado,quan do estes são limitados,por ocasião do desenvolvimento da espiga podem não ser suficientes,provocando redução em seu desenvolvimento, ou mesmo seu abortamento. Esta dominância apical tem sido confirmada por ANDERSON (1967) através de estudos de equilibrio hormonai, por SANFORD et ali $(1965)$ ao demonstrarem uma máior concentração de nitrogênio nos pendões de plantas férteis em relação às estéreis, e que este nitrogênio usado pa ra produção de pólen poderia ser o responsável pela diferença na produção observada e, por PATERNIANI (1981 e 1981b) ao demonstrar que o tamanho do pendão influj na posição relativa da espiga no coimo. Segundo este autor, sendo o pendão também um depósito importante, a 1 ém da espiga, ele na medida de seu maior tamanho, exercerá uma forte atração pelos fotossintetizados, e assim influirá na posição da espiga que se desenvolverā em posição mais alta na planta onde os fotossintetizados se encon tram em maior concentração por influência do pendão.

Outro efeito muito importante do pendão é o seu sombreamento sobre as folhas o qual serà tanto maior quanto maior for o pendão e a densidade de plantio. DUNCAN et alii (1967) realizaram estudos com o híbrido 'Pioner $3558^{\prime}$ e concluiram que o sombreamento pelo pendão, pode levar a reduções 
na produção de $4 \%$ a $12 \%$, para densidades de 25.000 a 75.000 plantas/ha. Devé-se observar que os milhos americanos tem pen dões menores que os brasileiros e, assim sendo, para as nossas condições deve-se esperar reduções mais acentuadas na produção. Para verificar o efeito do sombreamento pelo pendão, HUNTER et alii (1969) fizeram um trabalho em que a planta com o pendão produziu $4.700 \mathrm{~kg} / \mathrm{ha}$, sem o pendão $5.600 \mathrm{~kg} / \mathrm{ha}$ e com o pendão cortado, porém recolocado no mesmo lugar, $4.600 \mathrm{~kg} / \mathrm{ha}$. Pelos seus dados o pendão não competiu por nutrientes mas pela energia so lar, ao interceptä-1a e sombrear as folhas. Os autores chamam a atenção para o fato de ao se arrancar o pendão a injüria pro vocada poderia estar afetando a produção,e portanto não se poden do concluir categoricamente que não tenha havido competição en tre pendão e espigas. Por outro lado, a densidade de plantio foi relativamente baixa e sabe-se que o efeito da competi ção do pendão é maior nas maiores densidades.

Como demonstrado por GROGAN (1956) o despendoa mento pode aumentar a produção, com o que concordam os trabaThos de CHINWUMA et alii (1961), HUNTER et alii(1969), Schwanke citado por MOCK e PEARCE (1975) e LAMBERT e JOHNSON (1978). Por outro lado, pendões de plantas macho-estéreis também podem con tribuir para produções maiores. CHINWUBA et alii (1961) observaram produções superiores das formas nilacho-estéreis em relação às respectivas versões normais, em torno de $41,2 \%$ e $20,6 \%$ para as densidades de plantio de 67.950 e 32.740 plantas/ha, 
respectivamente. DUVICK (1958), demonstrou,por outro lado, que a produção de milho pode sér aumentada pela macho-esterilidade, mas que existe interação significativa entre esta e o genótipo em questão, bem como com o local e a densidade de plantio. Uma outra alternativa,que não o despendoamento ou macho-esterilida de,tem sido sugerida para a diminuição do efeito de dominância apịcal e sombreamento, e se refere à obtenção de.' pendões menores. BUREN et a lii (1974) observaram correlações negativas e significativas entre pendões maiores e produção. Resultados semelhantes foram obti dos por GERALDI et alii (1977) e souzA Jr. et alii (1981).

o tamanho do pendão pode ser expresso pelo seu peso, comprimento, número de ramificações, número de espiguetas, entre outros, porēm o nümero de ramificações tem demonstrado ser um dos meios mais viáveis para a sua avaliação. GERALDI et aiii (1977) demonstraram que entre o peso e nümero de ramificações este $\bar{u} 1$ timo foi mais responsável pela correlação negativa com a produção e ainda de herdabilidade mais elevada $(45,8 \%)$. ANDRADE e MIRANDA FILHo (1979) além destes dois componentes também avaliaram o comprimento do pendão,tendo en contrado herdabilidade maior para número de ramificações. Os valores encontrados para o coeficiente de herdabilidade foram de $61,6 \%$ e $74,1 \%$, a o nível de plantas e média de progênies,respectivamente. Pelos dados obtidos por estes autores pode-se observar que o referido caráter é de fácil seleção e que atra vés de umá simples seleção massal deve-se ter eficiência satí 
fatória. Em um programa de seleção massal para menor tamanho de pendão, PATERNIANI e GERALDI (1980), em três ciclos de sele ção no 'Piranão VD-2!' conseguiram.ganhos de $21 \%$ e, em um ciclo de seleção no 'Piranão VF-1' um ganho de $7 \%$ na redução do pendão. Com relação à produção não foram observadas diferenças na média dos dois ensaios realizados, entretanto no local de médias de produção mais baixas, a população de pendão menor produziu $6 \%$ a mais.

A Iiteratura tem mostrado que a se?eção para pen dões pequenos diminui a dominância apical,o mesmo ocorrendo com o aumento da prolificidade, o que indica que estes dois caracte res devem estar estreitamente relacionados. SouzA Jr. et alii (1981) conduziram um trabalho a respeito,e encontraram uma cor relação genética aditiva entre produção de grãos e número de ramificações de $-0,441^{\circ}$, produção de grãos e prolificidade de 0,941, nümero de ramificações e prolificidade de -0,648. Entretanto, quando obtiveram as correlações aditivas parciais,observaram que a correlação entre produção e número de ramificações passou até mesmo a ser positiva $(+0,655)$, quando eliminada a influência da prolificidade. A correlação negativa entre produção e nümero de ramificações é consequência da correlação positiva entre produção e prolificidade. Os autores chamaram a atenção, entretanto, para as condições de estresse de umidade ocorrida no ensaio e que devem ter aumentado a importância da prolificidade para o desempenho das progênias avaliadas. 
2.8. Plantas de Porte Baixo

\subsubsection{Obtenção de Plantas Baixas}

Os melhoristas de milho no País têm reconhecido, de uma maneira geral, a necessidade da redução da altura das plantas como um meio de diminuir o acamamento de plantas. Isto tem sido feito através da introdução de gene braquítico-2 (br-2) ou pela seleção de plantás mais baixas em populações com varia bilidade para o caráter. As duas alternativas são välidas, não havendo uma vantagem clara ou resultados experimentais que dis criminem uma delas. Em consequências, os melhoristas tem tra balhado com uma ou outra alternativa, segundo suas preferências. No ciaso específico deste trabalho a preocupação será em relação à utilização do gene br-2 como meio de redução da à1tura da planta.

Vārios genes maiores podem ser responsáveis pela redução da planta em milho. Entretanto o gene braquítico-2 tem sido considerado o que acarreta menores mudanças nas características agronômicas e de espigas (SINGLETON, 1959; KHERA et alii, 1975; BANDEL, 1978). Em vista disto é também o gene mais apropriado para ser utilizado em melhoramento de plantas.

o caráter braquítico foi descrito pela primeira vez em milho por KEMPTON (1920) baseando-se nos conceitos de 
cook, citado pelo referido autor, o qual considerou como braquíticas as plantas baixas cujos internódios são mais curtos, sem uma correspondente mudança em seu nümero e tamanho de outros órgãos. Kempton citou os trabalhos de dois outros autores Hartley e Gernet os quais descreveram plantas anãs já em 1912 e que aparentemente deveriam tratarem-se de braquiticas. Trinta anos após, LENG e VINEYARD (1951) descreveram o gene br-2 nos estoques de braquíticos "Oakes dwarf" e "R 4 dward". Os genes br-1 e br-2 foram considerados por LAMBERT (1963) situados em loci diferentes, do cromossomo 1. A forma braquítica é considerada recessiva e a dominância da forma normal, entretantö, nem sempre é completa. ScOTt e CAMPBELL (1969) noticiaram reduções em torno de $10 \%$ na altura das plantas, de cruzamentos entre linhagens normais e braquíticas, em relação aos respecti . vos cruzamentos de linhagens normal e normal. SINGLETON (1959) encontrou redụções em torno de $12 \%$. Também KHERA et aliii(1975), observaram decréscimos por volta de $15 \%$, no porte das plantas heterozigotas para o gene br-2, de cruzamentos intervarietais en tre a variedade braquitizada "Vijav" e outras variedades normais.

A introdução do referido gene em linhagens ou populações é muito fácil,por se tratar de uma herança mendeliana simples, e por isto é particularmente interessante ao me 1horamento. 
As plantas braquíticas de mi tho caracterizam-se por uma marcante redução do comprimento dos internódios, especialmente aqueles abaixo da espiga (LENG; 1957), não havendo uma proporcional redução de outros órgãos. Embora esta afir.mação tenha sido frequente na literatura,värios trabalhos têm demonstrado outras alterações na planta com a introdução do ge ne braquítico, ainda que não nas mesmas proporções como as redu ções do comprimento dos internódios e consequentemente da altu ra da planta.

\subsubsection{Alterações no Colmo da Planta}

A redução da altura das plantas pelo gene br-2 em consequência do encurtamento dos internódios acima e abaixo da espiga, tem sido demonstrado claramente pela literatura. Nas Tabelas 1 e 2 são apresentados alguns resultados que demonstram a extensão destes efeitos, tanto em linhagens como em híbridos e mesmo em populações.

Pelo que se pode observar dos resultados na Tabela 1, a redução na altura das plantas variou bastante em relação aos diferentes genótipos nos quais o referido gene foi 
Tabela 1 - Resultados médios obtidos por diferentes autores para os efeitos do gene br-2 na altura das plantas.

\begin{tabular}{|c|c|c|c|c|}
\hline \multirow{2}{*}{ A u t.ores } & \multirow{2}{*}{ Natureza do Material } & \multicolumn{3}{|c|}{ Altura das Plantas $(\mathrm{cm})$} \\
\hline & & Normais & Braquiticas & Braq./norm. (\%) \\
\hline ANDERSON e CHOW (1963) & Média de 3 hïbridos simples & $208(185-234)-$ a/ & $137(124-150)$ & $66(64-67)$ \\
\hline $\begin{array}{c}\text { SCOTT e CAMPBELL (1969) } \\
-\end{array}$ & $\begin{array}{l}\text { Média de } 4 \text { Iinhagens } \\
\text { Média de } 3 \text { híbridos simples } \\
\text { Média de } 4 \text { hîbridos simples } \\
\text { Br-2 br-2 }\end{array}$ & $\begin{array}{l}141(86-178) \\
256(254-258) \\
233(229-242)\end{array}$ & $\begin{array}{r}82(75-100) \\
162(149-179)\end{array}$ & $\begin{array}{l}58(44-87) \\
63(59-70)\end{array}$ \\
\hline BULOW (1971) & $\begin{array}{l}\text { Braquítico } 691 \\
\text { AG } 105\end{array}$ & 195 & 127 & 65 \\
\hline CIMMYT (1972) & Tuxpeño & 307 & 213 & 69 \\
\hline LEITE e PATERNIANI (1973) & $\begin{array}{l}\text { Piranão } \\
\text { AG } 257 \\
\text { Centralmex }\end{array}$ & $\begin{array}{l}224 \\
233\end{array}$ & 153 & $\begin{array}{l}68 \\
66\end{array}$ \\
\hline PATERNIANI (1975) & Piranão MIII & & $189(154-211)$ & \\
\hline RISSI et alii (1975) & $\begin{array}{l}\text { Piranão } \\
\text { CIII }\end{array}$ & 255 & 190 & 74 \\
\hline SINGH e RAY (1979) & $\begin{array}{l}\text { Média de } 5 \text {. Iinhagens } \\
\text { Média de seus } 10 \text { hîbr.simples }\end{array}$ & $\begin{array}{l}221(187-244) \\
245(224-255)\end{array}$ & $\begin{array}{l}158(143-170) \\
177(166-193)\end{array}$ & $\begin{array}{l}71(62-82) \\
72(66-78)\end{array}$ \\
\hline
\end{tabular}

a/Valores entre parênteses referem-se à amplitude dos dados observados. 
Tabela 2 - Resultados médios obtidos por diferentes autores para os efeitos do gene br-2 na altura da espiga.

\begin{tabular}{|c|c|c|c|c|}
\hline \multirow{2}{*}{$A u t \circ r$ e s } & \multirow{2}{*}{ Natureza do Material } & \multicolumn{3}{|c|}{ Altura da espiga $(\mathrm{cm})$} \\
\hline & & Normais & Braquíticas & Braq./norm. (\%) \\
\hline IENG (1957) & Hỉbridos braquíticos & . & $(25-75)$ al & \\
\hline ANDERSON e CHOW (1963) & Média de 3 h́ibridos simples & $90(61-126)$ & $57(33-73)$ & $63(54-76)$ \\
\hline SCOTT ë CAMPBELL (1969) & $\begin{array}{l}\text { Média de } 4 \text { Iinhagens } \\
\text { Média de } 3 \text { híbridos simples } \\
\text { Média de } 4 \text { hîbridos simples } \\
\text { Br-2 br-2 }\end{array}$ & $\begin{array}{r}64(27-105) \\
119(113-123) \\
107(104-111)\end{array}$ & $\begin{array}{l}27(10-50) \\
65(59-78)\end{array}$ & $\begin{array}{l}42(24-78) \\
55(47-63)\end{array}$ \\
\hline CAMPBELL (1965) & $\begin{array}{l}\text { Hỉbrido braquitico } \\
\text { Hîbrido braq. modificado }\end{array}$ & $\cdot$ & $\begin{array}{l}45 \\
75\end{array}$ & \\
\hline BULOW (197i) & $\begin{array}{l}\text { Briquitico } 691 \\
\text { AG } 105\end{array}$ & 110 & 60 & 55 \\
\hline LEITE e PATERNIANI (1973) & $\begin{array}{l}\text { Piranão } \\
\text { AG } 257 \\
\text { Centralmex }\end{array}$ & $\begin{array}{l}131 \\
14.7\end{array}$ & 76 & $\begin{array}{r}58 \\
52\end{array}$ \\
\hline PATERNIANI（1975） & Piranão MIII & & $106(78-121)$ & \\
\hline RISSI et alii (1976) & $\begin{array}{l}\text { Piranão } \\
\text { CIII }\end{array}$ & 149 & 92 & 62. \\
\hline
\end{tabular}

a/Valores entre parênteses referem-se à amplitude dos dados observados. 
introduzido. No trabalho de SCOTT e CAMPBELL (1969), por exem plo, a introdução do gene em quatro diferentes linhagens promo veu reduções na altura que variaram de $44 \%$ a $87 \%$ das respectivas formas normais. Esta interação do efeito do gene com os diferentes genótipos foi observada tanto em linhagens como em híbridos (THOMPSON e EVERETT, 1963; SINGH e RAY, 1979). Aparen temente pelo que se pode observar nas Tabelas 1 e 2 esta inte ração foi maior ao nível das linhagens do que dos híbridos.

Além dos genes maiores que controlam a altura das plantas, como o br-2, existem também múltiplos genes menores que promovem no caräter uma herança quantitativa. A ação destes dois mecanismos e a interação entre eles é que vai determinar geneticamente a potencialidade de crescimento de uma planta (ANDERSON e CHOW, 1963).

A literatura tem noticiado um efeito diferente do gene braquítico-2 nos intermódios acima e abaixo da espiga, reduzindo mais intensamente o comprimento destes ültimos(THOMPSON e EVERETT, 1963). SCOTT e CAMPBELL (1969) encontraram, em híbridos de linhagens braquitizadas, reduções do comprimento dos internódios para $55 \%$ e $71 \%$ dos respectivos normais,para os internódios abaixo e acima da espiga, respectivamente. Nas Tabelas 1 a 2, os resultados apresentados referentes ao trabalho destes mesmos autores mostram valores médios para a altura de espigas de $27 \mathrm{~cm}$ e $65 \mathrm{~cm}$ para as 1inhagens e híbridos avalia- 
dos, respectivamente. Na amplitude da variação apresentada pe las 1 inhagens observou-se em uma delas altura extremamente bai xa de espiga, em torno de $10 \mathrm{~cm}$.

À posição relativa da espiga sendo mais baixa na planta, apresenta a vantagem de oferecer maior resistência ao acamamento. Entretanto,quando muito baixa pode criar dificuldades para a colheita mecânica. Uma altura de espiga da or dem de $60 \mathrm{~cm}$ deve ser o critério mínimo acẹtável para não haver problemas de colheita (ANDERSON e CHOW, 1963): Resultados apresentados por estes, autores mostraram que de três híbridos simples estudados, um apresentou a a1tura de espiga com $33 \mathrm{~cm}$, portanto abaixo do limite crítico. Pela Tabela 2 observam-se outros resultados em que alturas da espiga abaixo do desejaclo foram obtidas.

CAMPBELl (1963) observou que braquitizando-se 1i nhagens mais a1tas, as formas braquíticas foram também mais a 1tas bem como a altura da espiga. Segundo ele os híbridos de linhagens altas braquitizadas não devem apresentar problemas de altura de espiga, e a isto ele chamou de braquíticos modifi cados, pois em termos da altura, suas plantas estiveram mais prö ximos dàs altas do que das anãs. Por outro lado, PATERNIANI (1975) introduziu o gene br-2 numa variedade melhorada de mi1ho de germoplasma "Tuxpeno", e encontrou uma variação para a 1 tura que ele considerou de muito baixa a praticamente plantas 
altas. Por seleção o autor selecionou para porte médio (em tor no de $190 \mathrm{~cm}$ ) com a1tura de espiga satisfatória (em torno de $105 \mathrm{~cm})$. E interessante notar que graças à ampla variação do porte na população braquitizada,pode-se selecionar para a altu ra de plantas e de espiga que se deseje. Numa avaliação de seis populações braquíticas de milho do Departamento de Genéti ca da Escola Superior de Agricultura "Luiz de Queiroz", em cru zamentos dialélicos SoUZA Jr. e ZINSLY (1981) observaram varia ções de $157 \mathrm{~cm}$ a $195 \mathrm{~cm}$ e $85 \mathrm{~cm}$ a $122 \mathrm{~cm}$ entre as jopulações e seus híbridos para altura da planta e da espiga,respectivamente. Por estas observações pode-se verificar que a altura de planta e espiga estão dentro de padrões que somente podem auxiliar a colheita mecânica.

Como a altura da planta é função não. somente do comprimento dos internódios, mas também de seu número, alguns trabalhos também estudaram o efeito do gen br-2 a este respeito. ANDERSON e CHOW (1963) não encontraram diferenças para o número total de internódios entre plantas nromais e braquíticas, em três hỉbridos simples estudados. O número de internoo dios nas duas categorias de plantas esteve em torno de 16. Por outro 1ado, SCOTT e CAMPBELL (1969) encontraram uma redução de seu número nas formas braquíticas $(10,3)$ em relação às normais $(12,1)$, sendo esta diferença explicada especialmente pela mudança encontrada abaixo da espiga. Os resultados observados por estes dois últimos autores, entretanto, não refletem o nú- 
mero real de internódios da planta pois a metodologia usada foi a de cortar a planta rente ao solo e na parte destacada superior contar-se o número de internódios. Como a forma braquítí ca deve ter maior número de internōdios sob o solo, haja visto a não observação de raízes advéntícias expostas, ficou subava1iada.

Uma das consequências mais importantes da dimi nuição do comprimento do colmo é a redução.de seu acamamento, característica esta considerada por alguns melhoristas, nas con dições brasileiras, como tão importante quanto a produção. Ganhos em produtividade podem não serem tão interessantes se o acamamento mantiver-se muito elevado. Especialmente quando a colheita é mecanizada sua importância se acentua mais, pois a mäquina não coleta espigas do chão.

Observações interessantes foram feitas por LENG (1957) a respeito do acamamento de plantas braquíticas. Segun do o autor, numa condição particular onde ventos fortes provo caram o acamamento de praticamente todas as plantas dos híbridos normais, praticamente impossibilitando a colheita mecânica, nos braquíticos promoveu, em média, apenas $40 \%$ de acamamento, havendo híbridos que mantiveram $100 \%$ de suas plantas eretas. Resumindo suas observações de três anos o autor considerou que os braquíticos no geral apresentaram uma excepcional resistên cia ao acamamento os quais, notadamente sob condições desfavo 
räveis, apresentaram grau de resistência não comparävel. com qualquer dos híbridos normais testados.

\section{ANDERSON e CHOW (1963) estudaram separadamente}

o acamamento por quebra do colmo e de raiz e encontraram uma resistência elevada dos braquíticos (média de três híbridos sim ples) em relação aos normais quanto ao quebramento do colmo sendo observados os valores de $2,5 \%$ e $23,0 \%$, respectivamente. Quanto ao acamamento de raiz a avaliação foi feita por nota, e em. dois dos três hïbridos estudados não houve diferença entre as versões normais e bŕrauíticas, porém para o terceiro notou-se um maior acamamento para a forma braquítica. Resulta dos semelhantes foram obtidos por BüLow (1971) o qual na compa ração entre uma variedade braquítica e um híbrido normal usado como testemunha, encontrou $12,7 \%$ e $22,5 \%$ de plantas com colmo quebrado, $€ 20,8 \%$ e $20,0 \%$ de plantas acamadas pela raiz, respectivamente. Ao comparar algumas populações e híbridos braquíticos, PATERNIANI (1980) observou uma média de $25 \%$ de p1antas acamadas e apenas $4 \%$ de quebradas, o que segundo. outor demonstra uma tendência a menor quebramento de colmos em relação ao acamamento de raiz.

Outros autores também têm relatado menor acamá mento para as formas braquíticas em relação às normais, sem dis crimina $\dot{r}$ a sua natureza (CAMPBELL, 1965; SINGH e RAY,1979). I s to tem sido explicado em função de um centro de gravidade mais 
baixo na planta baixa. A nosso ver o melhor comportamento obtido pelas formas braquíticas quanto ao quebramento também pode ser explicado por uma aproximação maior dos nós das plantas, os quais têm nas suas proximidades um tecido mais resistente è um diâmetro maior. o próprio caule tem sido observado ser mais grosso nas formas braquíticas (THOMPSON e EVERETT, 1963; LEITE e PATERNIANI, 1973; GALVÃO e PATERNIANI, 1974).

\subsubsection{A lterações nas características folia- res}

Como foi visto, aparentemente nao hà variação no numero de internódios entre versões normais e braquíticas. Logo como esta característica está associada ao número de fo1has da planta, para esta também não deve-se esperar variações entre os tipos de planta considerados. ANDERSON e CHOW (1963) estudando o carāter número de folhas em três hïbridos simples nas versões normais e braquíticas em diferentes fases do ciclo das plantas, observaram que, em média, não houve diferenças en tre as plantas baixas e altas, embora tenham observado aos 95 dias um maior número de folhas ativas para as formas braquítí cas, o que foi atribuído pelos autores a uma maior persistência das folhas neste tipo de planta. SINGH et alii (1979) encontraram resultados similares, ao verificarem em cinco linhagens 
e nos seus respectivos dez hỉbridos, nas formas normais e braquíticas, não haver diferença entre as médias das mesmas quanto ao Indice de Area Foliar em diversas fases de todo o ciclo das plantas. Um trabalho mais detalhado foi desenvolvido por STEIN (1955) o qual observou a formação de folhas em. linhas isogênicas diferindo para o caräter br-2, durante a embriogênese e fase de plântula. Os seus dados demonstraram que o número de folhas formadas, em torno de 19 no total, foi muito simi 1 ar entre os dois materiais.

Medições realizadas, na folha do nó da primeira espiga, por ANDERSON e CHOW (1963), mostraram que em dois híbridos simples, as formas braquíticas apresentaram folhas significativamente mais curtas com aproximadamente $12,5 \mathrm{~cm}$ a menos do que a formạ norma1, porém também significativamente mais lar gas em torno, de $1,5 \mathrm{~cm}$. Como consequência, não houve variação entre as formas altas e baixas quanto à área da respectiva folha. Num terceiro híbrido, entretanto, observaram um aumento da área da referida folha, na forma braquítica,em função de um aumento na largura da folha sem um respectivo encurtamento da mesma.

A despeito de ser aceito de modo geral que o ge ne br-2 atua aumentando a largura das folhas (POEY,1973), é pos sível vèrificar-se, em populações com variabilidade genética e braquitizadas, plantas baixas e de folhas até mesmo mas estreitas 
que a média observada na população original antes da introdução do referido caráter.

\subsubsection{Influência na Produção e seus Componen tes}

De uma maneira geral os estudos sobre o efeito do gene br-2 na produção têm sido feitos predominantemente em híbridos de linhagens braquitizadas, ou mesmo em linhagens, e os resultados mostrados pela literatura têm sido desestimulado ress. No geral as produções das formas braquíticas têm sido in feriores às respectivas versões normais, conforme se pode obser var na Tabela 3 que resume os dados de alguns trabalhos a respeito. Entre os 11 citados, oito apresentaram resultados nega tivos para as formas baixas.

Devido às produções insatisfatórias das pḷantas braquíticas e em função da controvérsia criada a respeito de seu valor, a revista CROPS AND SOILS (1960) ouviu vários es pecialistas a respeito do futuro dos respectivos milhos e algu mas opiniões valem a pena serem consideradas aqui.

o Dr. Leng e Dr. Anderson consideraram que embo ra as produções das formas braquíticas sejam no geral inferiores $(20 \%)$, em alguns casos têm se mostrado superiores, o que 


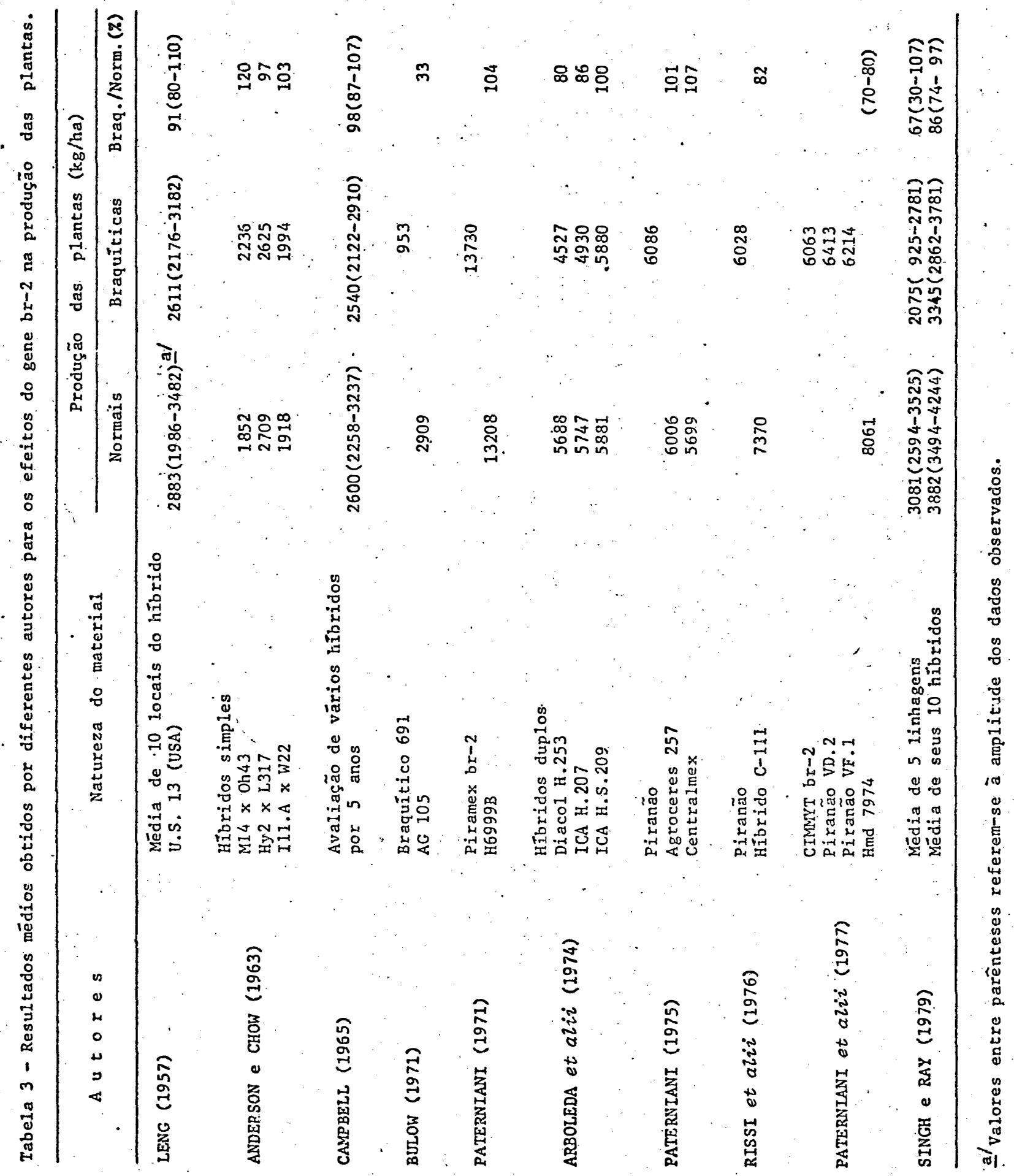


demonstra uma certa potencialidade para o $\dot{f} u t u r o . \quad$ Quanto à maior facilidade da colheita mecânica em função do menor acamamento e volume de planta dentro da colhedeira, a posição mui to baixa da espiga, por outro lado, pode ser desvantajosa,pois, especialmente em condições de baixa umidade, pode levar a uma perda muito grande, uma vez que as espigas muito baixas podem" não ser colhidas pela máquina.

o Dr. Lonquist, embora nã் trabalhando com os braquíticos considerou que a menor produtividade de tais materiais poderia ser superada por melhoramento e, no futuro obter-se tipos tão produtivos quanto os de porte normal. Acres centando, o Dr. Sprague sugeriu que outros mëtodos que não exclusivamente os de retrocruzamento deveriam ser utilizados.

Um dos primeiros programas a trabalhar com certa intensidade com o gene braquítico foi o da "IZlinos Exp. Estation" (U.S.A.) e que foi.relatado por LENG (1957). Entretanto seus resultados foram considerados pelo autor como $\therefore$ desencorajadores, pela redução nas produções dos híbridos de por te baixo (Tabela 3). o autor citou ainda observações de uma menor capacidade de competição com as plantas daninhas.

No Mississipi (USA) o programa com braquítico iniciourse em 1957 e CAMPBELL (1975) relatou os resultados obti dos, onde híbridos braquíticos (Tabela 3) foram obtidos com pro 
duções atē mesmo semelhantes e maiores que os tipos normais. 0 autor chamou a atenção para se trabalhar com o que ele chamou de braquíticos modificados; isto é, plantas que se aproxí mem em porte, mais das normais do que das anãs. Também o refe rido autor ressaltou vários fatores que segundo ele foram res ponsáveis pelo insucesso no trabalho combraquíticos. 0 porte excessivamente baixo de linhagens braquitizadas reduziu seu potencial produtivo ao ponto de muitas vezes inviabilizá-1as to talmente. 0 autor sugeriu a introdução do gene br-2 em 1inhagens originalmente de porte alto, obtendo-se assim braquíticos mais altos também. As plantas baixas deveriam ser ava1 iadas em áreas onde a altura das plantas normais consticui-se em problema real. Programas relativamente pequenos de conversão de hỉbridos limitaram, em muitas circunstâncias as possibi lidades de sucesso, não permitindo, por uma questão de probabiIidade, a obtenção de. genótipos compatíveis com o gene br-2. A pressa na obtenção de hỉbridos braquíticos fez com que poucas gerações de retrocruzamento fossem empregadas na incorporação do respectivo gene às linhagens, não se recuperando com isto a capacidade de combinação das mesmas. Não se utilizou a ação dos genes modificadores. Os testes no geral foram feitos em condições de manejo. semelhantes ao das plantas altas, sendo que o certo seria comparar os dois materiais cada um em sua condição ótìma.

PATERNIANI (1975) acrescentou ainda como moti 
vo de insucesso nos programas americanos, a introdução do gene br-2 em linhagens. Segundo o autor, o gene não se adapta à to das as linhagens em que é introduzido e por tratar-se de uma linha pura não é possível modificar-se tal situação: A alternativa apresentada seria a transferência do gene br-2 para populações onde ele pudesse encontrar nas gerações segregantẹs uma condição de maior equilíbrio. Linhagens extraîdas de tais populações poderiam ser mais viāveis tạto de "per si" como em cruzamentos. A seleção das linhagens seria concomitante com mu danças nas frequências de genes modificadores, os quais permiti riam ao melhorista selecionar para a altura que melhor 1 he con viesse.

Bülow (1971) obteve uma população de milho nas versões normal e braquítica e verificou para esta um desempenho pior em termos de produção de grãos: Isto ao nosso ver é perfeitamente justificável pois a simples introdução do carāter em populações não significa por si só a obtenção de êxito. En tretanto uma nova condição de equilíbrio entre o gene br-2 e os demais da população deve ser buscada por seleção, o que é perfeitamente possível, pois a população segregante dá oportunidade para que tal aconteça, como ocorreu no processo de obtenção do milho Piranão (PATERNIANI, 1975).

Com relação aos componentes da produção afetados pela presença dó caráter braquítico, ANDERSON e CHOW (1963) 
encontraram para um hỉbrido, aumento da produção em função de grãos mais pesados. Nos três híbridos simples estudados pelos autores, o comprimento da espiga foi praticamente igual nas duas versões, havendo entretanto, uma tendência das formas bra quíticas terem menor nümero de fileiras de grãos nas espigas, porém, maior número de grãos nas respectivas fileiras, diferenças estas não significativas.

SINGH e RAY (1979) observaram em cinco Iinhagens. e seus dez respectivos hỉbridos simples, nas versões normais e braquíticas, que estas ültimas apresentaram uma frequên cia de plantas estéreis em média de $23,3 \%$ enquanto que as nor mais de $12,0 \%$, característica esta considerada pelos autores como uma das responsáveis pela menor produtividade das formas braquiticas. Nem todos os braquíticos entretanto mostraram es ta mesma tendência. O peso de grão; por outro lado, foi 1igeiramente maior, em média, nas formas braquíticas. GALVÃo e PATERNIANI (1974) também obsèrvaram uma maior frequência de - plantas estéreis em vários níveis de densidade de plantio estú dados. Outra das causas de menor produtividade dos milhos bra quíticos tem sido relacionada com a dificuldade de emissão dos estilo-estígmas, devido à pressão exercida pelas bainhas,especialmente quando o encurtamento dos entrenós é muito exagerado (PENDLETON e SEIF, 1961; POEY, 1973), resultando em espigas com falhas de grãos, CAMPBEL (1965) não observou nos seus ma 
teriais braquíticos espigas com falhas de grãos superior a observada nos milhos normais. Também não notou esta esterili dade maior nos braquiticos, mesmo em densidades em torno de $55.000 \mathrm{plantas} / \mathrm{ha}$.

Para praticamente todas as características analisadas, influenciadas pela presença do caräter braquítico, po de-se observar uma variação de intensidade de suas manifestações em função do genótipo. Assim tem sido para altura de planta, acamamento, produção, etc. Nestas.circunstâncias, a in trodução do gene br-2 em populações de base genética ampla, deve criar condições favoráveis para a obtenção das mais variadas associações entre o caráter braquítico e os demais, de tal sorte que a obtenção de associações mais harmoniosas entre as características podem ser conseguidas, resultando em individuos de melhor produção.

Os trabalhos a respeito do gene braquítico foram comumente realizados pela introdução do mesmo em materiais de base genética estreita e seu efeito avaliado em linhas isogênicas e principalmente em híbridos de linhagens braquitizadas, em relação às respectivas formas originais. Nestas circunstâncias seria pouco provável que a introdução de um gene dentro de um genoma, equilibrado e resultante de uma intensa seleção, não viesse alterar tal equilíbrio, com prejuỉzo geral do genótipo, especialmente em se tratando do caráter braquíti- 
co que provoca mudanças morfológicas acentuadas quando presen te. Diante de tais considerações, a introdução do referido gene seria mais viável em germoplasmas de base genética ampla. Possivelmente estes também teriam seu equilíbrio genético alte rado, mas em função da variabilidade presente, uma nova condi ção de equilíbrio poderia ser encontrada, em consequência das recombinações e seleção.

Pelo que foi colocado, o estudo do efeito de um determinado gene sobre outros caracteres, inclusive a produção, não parece ser muito apropriado através do uso de linhas isogệnicas como tem sido sugerido atê recentemente (TRENBATH e ANGUS, 1975; WILSON, 1981). O efeito de um gene na determinação de um fenótipo é função de sua ação direta e de sua intera ção com os demais genes do genótipo e com ó ambiente. Se uma linhagem ou variedade tem seu potencial produtivo diminuido pe la presença de um gene, isto não significa necessariamente uma consequência de seu efeito direto, mas pode ser o resultado de sua interação com os demais do genôtipo. Também não significa que esta interação não possa ser positiva em outro germoplasma. Por outro lado, a idéia de que estes estudos,quando realizados numa amostragem adequada de germoplasmas, podem refletir a ação do gene pois diminuem o efeito de sua interação,também não é argumento satisfatório pois, embora possa realmente diminuir o efeito destá interação, não a elimina. No caso específico do 
br-2, o qual determina mudanças acentuadas nas características morfológicas e fisiológicas da planta, o normal é esperar-se - que sua presença cause um desequilíbrio de funções nas caracte risticas da planta, as quais evoluiram harmonicamente para um máximo de adaptação, por séculos de seleção.

2.8.3. Eficiēncia do Milho Braquítico

o trigo anão do México e o arroz milagroso das Filipinas, responsáveis pela Revolução Verde, são exemplos do grande potencial que representam os genes para nanismo,uma vez que foram eles um dos responsáveis pela alta produtividade dos respectivos materiais. Em milho, por outro lado, seu potencial produtivo além de apenas raramente ter aumentado,com muita frequência foi reduzido, com a introdução dos referidos genes. Estes resultados não significam necessariamente que plan 
tas baixas de milho näo sejam viāveis. Os trabalhos realizados a respeito têm mostrado uma série de inadequações, conforme já discutido e por outro lado, alguns resultados positivos são uma boa indicação da potencialidade das plantas braquíticas, me 1hor mesmo do que uma anālise do comportamento médio do carāter.

Um dos meios que se tem buscado para aumentar a potencialidade produtiva do milho é através, do aumento da densidade de plantio (LAMBERT, 1971). Entretanto, com as plantas tradicionais de porte alto, a partir de determinado limite. os probiemas de acamamento e plántas estéreis se acentuam a ponto, inclusive, de reduzir a produtividade. As plantas de porte baixo por competirem menos por luz poderiam suportar densidades populacionais mais elevadas e possivelmente maiores aplica ções de fertilizantes, sem apresentarem os problemas referidos. e por consequência aumentarem o potencial produtivo. Em arroz, segundo JENNINGS (1964), a melhoria das práticas culturais, par ticularmente densidade de plantio, controle de água e níveis de nitrogênio, não garantiram ganhos em produção nas variedades de porte alto, pois estas frequentemente respondiam em altura ainda maior, acamamento e esterilidade.

A competição por luz numa cultura de milho se estabelëce entre folhas de uma mesma planta, entre plantas na linha de plantio e éntre linhas. A competição entre linhas por 
luz, ao nosso ver é menor para as formas braquiticas permitindo que se possa aumentar a densidade de plantio através de fileiras mais próximas. Na medida que aumenta a inclinação do sol em relação a um plano horizontal, mais rapidamente as plantas baixas deixarão de sombrear as vizinhas e por consequência menor a competição por $1 \mathrm{uz}$. A Figura 1 demonstra como a ārea projetada da sombra das plantas altas é maior, para um mesmo ângulo de incidência dos raios solares. Por outro lado, como o mi.1ho atinge sua altura máxima por ocasião da liberação do pólen, tanto em plantas a ltas como em baixas, e como estas flo rescem aproximadamente na mesma época, então as braquíticas crescem mais lentamente para terminarem com uma porte menor. Nestas circunstâncias, o efeito de sombreamento deve ocorrer alguns dias mais tarde no ciclo destas plantas,diminuindo desta forma também o efeito da competição por lụz. Com relação ao período para florescimento, ANDERSON e CHOW (1963) observa ram um retardamento de um a seis dias para os braquíticos, enquanto que SINGH e RAI (1979) e CIMMYT (1972) não encontraram diferenças.

Com relação à competição por luz entre plantas na linha, considerando-se os espaçamentos convencionais, a situação muda por completo, pois dada a proximidade entre plantas suas folhas estarão em forte competição. Considerando que o gene br-2 não altẹra o número de folhas, porém a altura da 


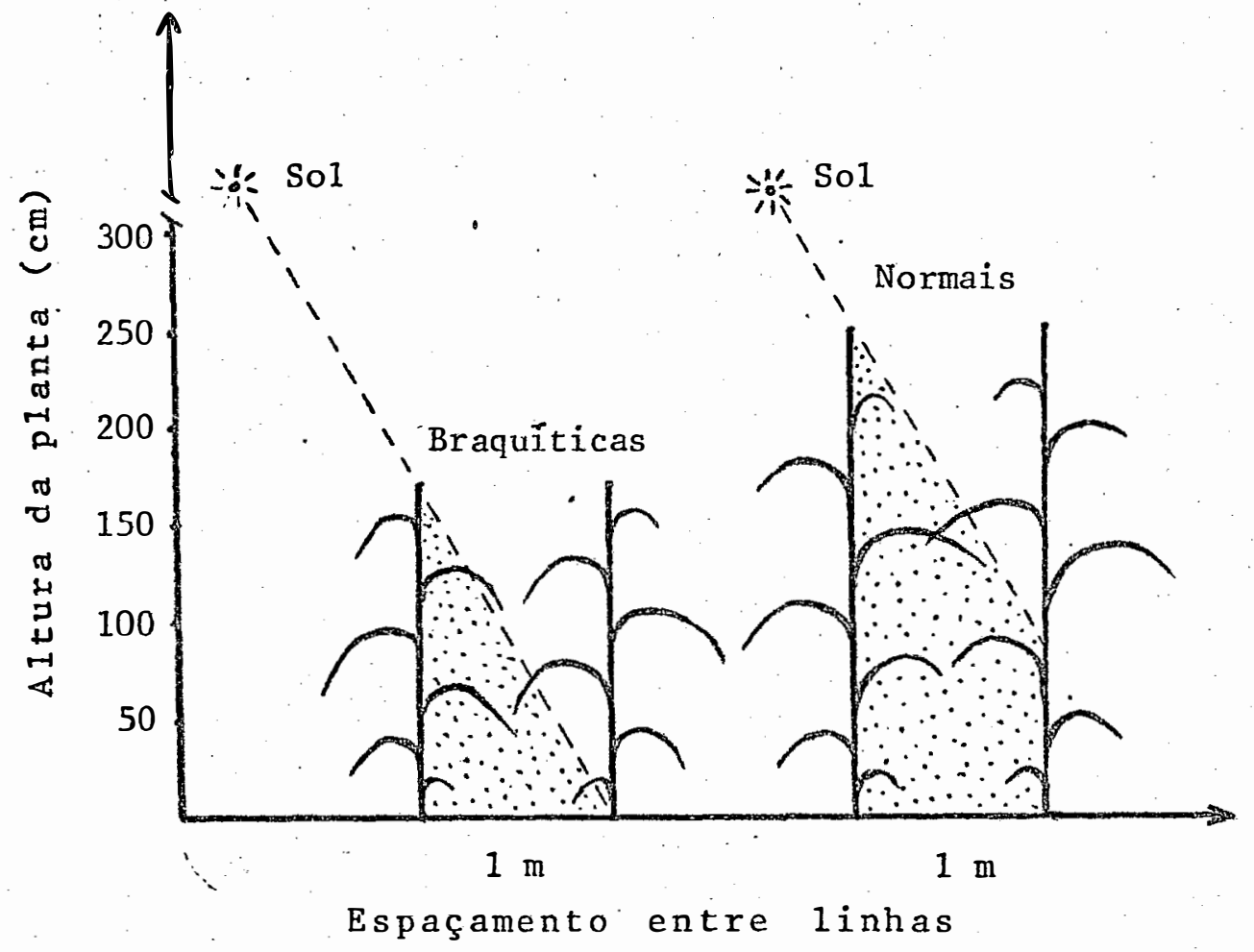

Figura 1 - Comparação entre plantas de milho braquíticos e normais com relação ao sombreamento. 
planta, resulta que elas ficam muitó próximas entre si no plano vertical e como folhas de plantas vizinhas se cruzam e se superpõem, o resultado será um acentuado sombreamento mútuo das mesmas, mais intenso que nas plantas normais. Nos braquíticos também a competição entre folhas da mesma planta,é agravada pẹ 1a tendência geralmente observada de folhas mais largas, além da proximidade vertical entre as mesmas (POEY, 1973). Esta com petição entre folhas foi demonstrada por KATTA e GIL (1970) os quais fizeram um experimento com uma população braquítica no qual dispuseram artificialmente as folhas acima da espiga em posição vertical e em outro tratamento dispuseram as folhas no sentido leste-oeste. No caso das folhas. eretas obtiveram um ganho em produção por volta de $8 \%$ e no caso de ambos tratamentos associados o ganho foi de $22,3 \%$. A criação de condição de distribuição mais uniforme de luz pelas folhas, como se demons trou, foi responsável pelo aumento do potencial produtivo.

o que se pode inferir a respeito do problema. de competição por luz nos milhos braquíticos, é que o aumento da densidade de plantio somente deverá promover respostas mais acentuadas que os tipos normais quando for feita pela redução do espaçamento entre linhas. Com relação ao aumento de densidade dentro da linha o esperado é uma resposta similar ou mesmo mais negativa em relação à observada para as plantas normais. Os resultados de pesquisa, envolvendo espaçamento e den sidade, mais completos foram fornecidos por PENDLETON e SEIF(1961) 
para as plantas braquíticas. Os autores avạiaram um hỉbrido duplo em dois locais, dois anos, em três espaçamentos entre $1 \underline{i}$ nhas $(51 \ldots \mathrm{cm}, 76 \mathrm{~cm}$ e $102 \mathrm{~cm})$ e seis densidades de p1antas $(29.652$ à 79.071 plantas/ha). A produção cresceu com a densidade até ụm ótimo por volta de 50.000 plantas/ha, tendendo a caìr após este níve1. O espaçamento de $76 \mathrm{~cm}$ entre 1 inhas, e. densidade de 50.000 plantas/ha, promoveu a maior produção do ensaio. Segundo os autores os espaçamentos entre linhas tive ram pouco efeito na frequência de plantas estéreis, entretan-. to o aumento da densidade alēm de um ótimo aumentou o número de plantas estéreis e o acamạmento. O híbrido braquítico estu dado tinha altura em torno de $160 \mathrm{~cm}$, portanto, similar aos va lores obtidos para as populações braquíticas brasileiras.

Densidades de plantio acima do recomendado para as condições'de cultivo no País, ( $50.000 \mathrm{plantas/ha)} \mathrm{foram} \mathrm{ava}$ liadas por GALVÃO e PATERNIANI (1974), mantendo-se constante o espaçamento de 1 metro entre 1 inhas de plantio. A variedade ' $P i-$ ranão' (braquítica) comportou-se quanto à produção, de forma similar ao hỉbrido de porte normal ' $A G-257^{\prime}$, entretanto exibiu uma maior frequência de plantas estéreis nas densidades maís altas. Um outro experimento realizado por LEITE e PATERNIANI (1973) envolvendo as mesmas populações do trabalho anterior,mostrou que aumentando-se a densidade de 4 plantas/m para 8 plantas/m, no espaçamento de um metro entre linhas, os materiais. Piranão e AG-257 aumentaram a produção de $3,8 \%$ e $11,8 \%$, respectivamente. 
Quando a mudança foi para uma densidade de 6 piantas/m e espaçamento entre 1 inhas de $0,75 \mathrm{~m}$ as produções aumentaram de $11,7 \%$ e $18,3 \%$, respectivamente para a forma braquítica e norma1. Este ensaio foi o resultado de apenas um ano e um local e a variação no espaçamento foí acompanhada de mudanças tambẻm na den sidade, dificultando a interpretação. RISSI et a $i i i(1976)$ avaliaram várias populações e hỉbridos braquíticos nas densidades de 50.000 a 62.500 plantas/ha, no espaçamento de $80 \mathrm{~cm}$; em quatro locais, encontrando aumento em produtividade similar en tre a mẻdia dos braquíticos e o híbrido normal usado como testemunha.

Embora os resultados com espaçamento e densidade de plantio sejam poucos com os milhos braquiticos,em linhas gerais pode-se dizer que eles apoiam as considerações feitas a princípio.

Outro aspecto que se pode considerar com relaf̧ão aos braquíticos se refere à sua capacidade de suportarem plantios em espaçamentos entre linhas mais apertadas e isto tém como consequência um maior número de plantas por área apro veitando a luz que na fase jovem da cultura é abundante e muito desperdiçada pelas plantas altas. Esta intercepcão maior de 1 uz, nesta fase, aumenta a capacidade competitiva da cultura com as plantas daninhas, anulando com isto uma das principais críticas feitas ao braquítico, isto é, maior problema de 
mato em seu cultivo. Tambēm uma maior eficiência na utiliza ção da água do solo pode sér considerada pois se menos luz a 1cança o solo, menor será a perda de água por evaporação e maior será a disponibilidade para a cultura.

A percentagem mais elevada de plantas estéreis nas formas braquíticas (GALVÃo e PATERNIANI, 1974; SINGH e RAI, 1979) em relação as de porte alto são uma indicação de que a forte competição entre plantas e entre folhas de uma planta pode. estar causando um efeito negativo mais acentuado nas braquíticas do que nas normais. Nestas circunstâncias seria inte ressante que o melhoramento de plantas se preocupasse em selecionar tipos que permitam maior penetração da luz solar. Caracte rísticas como folhas eretas, menor ramificação do pendão,. fo1has mais estreitas e até mesmo, possivelmente, menor nümero de folhas, seriam aconselháveis. Como a seleção para produção é relativamente difícil dada à sua baixa herdabilidade, ganhos maiores talvez possam ser obtidos indiretamente pela incorpora ção das características referidas, as quais são de fácil sele ção, e ao nosso ver esta seria uma das prioridades mais imedia tas do melhoramento nas populações braquíticas brasileiras. Em arroz as variedades modernas de alta produtividade associam à uma menor altura de planta também folhas mais eretas(IRRI,1966). Outra cạracterística que tambēm poderia ser muito útil, sugeri da por KATTA e GIL (1970) se refere à obtenção de plantas com 
folhas emergindo dos nós em diferentes direções. Isto contribuiria para reduzir o forte efeito de sombreamento consequente do arranjo de folhas em apenas duas fileiras opostas ao longo do caule, exibido pelo milho.

Uma maior tolerância à seca tem sido acribuída às formas braquíticas, constituindo-se numa de suas importantes propriedades pelo menor risco que oferecem em seu cultivo. Segundo POEY (1973) tem-se observado que em condições de estresse de umidade as plantas braquíticas mantêm-se mais turgidas e com as folhas mais verdes èm comparação com as variedades altas on dè, nas mesmas condições as folhas se tornam murchas e cloróti cas. O autor considera por outro lado, que em condições de ex cesso de umidade, elas tambẹm reagem mais convenientemente,gra ças ao que considerou como maior eficiência de translocação. Outros autores têm também noticiado maior tolerância à seca (TREGUBENKO e NEPOMNJASCIJ, 1971; SOLONENKO e CHALIK, 1975; FILIPPOV e VISHNEVSKII, 1982). Outra explicação para tal tole rância pode ser um sistema radicular mais abundante e que se estabelece mais rapidamente. As raízes adventícias das plan tas altas nascem de nós acima do solo enquanto que nas formas braquíticas devido ao encurtamento dos extremos, estas raízes já nascem sob o solo e portanto iniciando suas funções imediatamente、 Um processo mais eficiente de translocação conforme sugerido por POEY (1973) pode ser explicado por um menor gasto 
de energia no mesmo, uma vez que a fonte e o depósito encontram-se mais próximos nas plantas braquíticas.

Ao se observar as Tabelas 1 e 2 pode-se perceber que a altura das plantas e a a 1 tura das espigas das braquí ticas foi $60 \%$ a $70 \%$ e $50 \%$ a $60 \%$ das normais, respectivamente, o que equivale dịzer que a redução da altura da espiga foi relativamente mais acentuada que a da altura das plantas. Se por um lado a redução do porte já é importante fator para diminuir o acamamento, melhor ainda quando a espiga encontra-se em posi ção relativamente mais baixa na pianta. Este quadro vem façilitar o trabalho do melhorista de milho pois não. precisa se preocupar tanto em sua seleção com a altura da espiga,aumentan do-se com isto sua eficiência, pois é um carāter a menos a ser considerado.

A maior parte das colocações feitas neste ítem são conjecturas que necessitam comprovação experimental, entretanto foram feitas por inferência em função da revisão da literatura citada neste trabalho e portanto com certo fundamen to nos fatos discutidos. DUNCAN (1972) cita uma colocação interessante feita por Walt Whitman: "Teoria sem fato é fantasia, fato sem teoria é caos". 


\subsection{Considerações Gerais}

A revisão realizada neste trabalho teve o objetivo de demonstrar da maneira mais completa que nos foi possível, a importância das plantas braquíticas,tanto do ponto de vista agronômica quando de suas qualidades fisiológicas. As cạ racterísticas agronômicas têm sido bem exploradas pela literatura, entretanto muito pouco tem sido feito do ponto de vista fisiológico. Por este motivo, se fez um levantamento a respei to de alguns de seus aspectos estudados no milho de porte normal e em outras culturas, no sentido de criar fundamentos para discutir este ponto de vista nos milhos braquiticos.

Desta forma esperamos ter dado uma visão geral da influência do gene br-2 no contexto agronômico e fisiológico da planta, e assim também conseguido justificar este traba1ho cujo objetivo fundamental é observar se populações braquíticas de milho obtidas e selecionadas no Brasil apresentam-se como alternativas viáveis para as nossas condições. 


\section{MATERIAL E METODOS}

\subsection{Material}

Cinco populações de plantas de porte normal e cinco braquíticas relacionadas geneticamente às primeiras, foram utilizadas. Uma breve caracterização individual das populações de porte normal (indicadas pela letra A), bem como das correspondentes formas braquíticas (indicadas pela letra B), é dada a seguir. Antes porém convém esclarecer que as populações 'Maya(s)' foram desenvolvidas no Instituto Agronômico de Campinas e as demais no Departamento de Genética da Escola Superior de Agricultura "Luiz de Queiroz", de Piracicaba. As informações a respeito das populações foram obtidas de PATERNIANI et alii (1977), SAWAZAKI (1980) e de informações pessoais pelo Dr. Paterniani e Dr. Miranda.

1.A. 'ESALQ VD. 2'-Foi obtida a partir de 1965 por recombinação de populações introduzidas do CIMMYT, com predominância 
da raça 'Tucpeño', de grãos dentados brancos e amare1os. 0 material recombinado passou posteriormente por uma seleção para grãos dentados amarelos e melhoramento para produção pơr três ciclos de seleção entre e dentro de famílias de meios irmãos.

1.B. 'Piranão VD. 2' $^{\prime}$ Esta população, de grãos dentados amare los, resultou em primeiro lugar da seleção para porte. médio $( \pm 1,70 \mathrm{~m})$ a partir de geração $F_{2}$ do cruzamento da pó pulação 'ESALQ VD. 2'x 'Piranão VD. I.'. Posteriormente foi submetida a quatro cïclos de seleção massal para prolificidade. A população 'Piranão VD. I', doadora do gene br. 2, por sua vez foi obtida da geração $F_{2}$ do cruzamento 'Piramex' x 'Tuxpeño br-2'. Fstes dois materiais são milhos dentados, o primeiro amarelo e o outro branco, da raça Tuxpeño, originalmente introduzido do CIMMYT.

2.A. 'ESALQ VF. I' - E uma população de grăos duros, de cor la ranja, resultante de três ciclos de seleção entre e dentro de familias de meios irmãos. A população base foi for mada pela recombinação, realizada a partir de 1965, de miThọs introduzidos do CIMMYT, de grãos duros de cores bran ca e laranja, representando raças de Cuba, Colômbia e Amé rica Certral.

2.B. 'Piranão VF. $1 l^{\prime}$ - Resultante de quatro ciclos de seleção massal para prolificidade, de grãos duros e cor laranja, 
originou-se da seleção de plantas de porte médio $( \pm 1,70 \mathrm{~m})$ realizada na geração $\mathrm{F}_{2}$ do cruzamento 'ESALQ VF. I' x 'CIMMYT $b r-2^{\prime}$. Esta última variedade por sua vez, compreende germo plasma Cubano de grãos duros e cor laranja.

3.A. 'ESALQ VD. $4{ }^{\prime}$ - Refere-se ao mesmo germoplasma básico de 'ESALQ VD. 2', tendo sido entretanto selecionado para grãòs dentados e brancos, sem passar pelo melhoramento para pro dução como no caso da população de grãos amarelos.

3.B.' 'Piranão VD.4' - Esta população é semélhante a ao Pïranão VD. ${ }^{\prime}$, de onde foi obtida por seleção para altura de planta e grãos brancos, sem seleção para produção.

4.A. 'ESALQ VF.3' - Tambēm neste casó o material correspondente ao mesmo germoplasma básico que deu origem a 'ESALQ VF. I', porém neste caso selecionado para grãos duros brancos e não selecionado para produção.

4.B. 'Piranão VF. 3' - Corresponde à Piranão VF.1, porém diferindo dela por ter sido inicialmente selecionada para por te e grãos brancos e sem seleção adicional.

5.A. 'IAC Maýa 13' - Esta é uma variedade sintética de grãos dentados amarelos obtidas pela recombinação de várias 1i- nhagens e variedades de milho,seguida de melhoramento por vārios ciclos de seleção entre e dentro de famílias de meios irmãos e, ainda pela introgressão de material proí 
fico seguido de seleção para produção e prolificidade por mais trềs ciclos.

5.B. 'IAC Mayanão II" - Este tipo braquítico resultou do cruza mento de variedade 'IAC Maya' após já ter recebido introgessão para prolificidade, com o material 'Tuxpeño br-2', seguido de um retrocruzamento para 'IAC Maya' e sèleção para porte braquítico. Este material passou posteriormen te por dois cicilos de seleção para produção entre e dentro famĩlias de meios irmãos.

As populações'identificadas por ESALQ e Mayã são de porte alto e aquelas por Piranão e Mayanão de porte baixo.

Pela descrição das populações pode--se observar não tratarem-se de populações isogênicas para o caráter braquítico-2, mas que as altas e baixas guardam entre si grande afinjade genética. Também pode-se observar que as populações básicas utilizadas como doadores do gene br-2, no processo de obtenção das formas braquíticas, tinham afinidades pelas respectivas populações de porte alto, por tratarem-se de mate riais da mesma raça, o que leva à pressuposição de semelhanças para muitos dos genes dos respectivos germoplasmas. Isto alia do ao uso de várias populações cria condições para que as comparações entre portes sejam satisfatórias. 


\subsection{Métodos}

Os materiais constantes do trabalho foram avaliados em ensaios conduzidos em quatro localidades (Piracicaba, SP., Guỉra, SP., Matão, SP. e Ituitaba, MG.), no ano agrícola de $1981 / 82$.

Em cada local, o ensaio foi desenvolvido no delineamento experimento em faixas conforme sugerido por PIMENTEL GOMES (1963). Os experimentos foram implantacios em cada local em seis repetições com ạs parcelas constituídas de fileiras de $10 \mathrm{~m}$ de comprimento espaçadas de 1 m entre si. Como as populações de plantas altas e baixas foram dispostas em fai xas separadas, não se usou bordadura de parcela, mas das faixas, através de duas fileiras de plantas baixas quando ao lado das braquiticas e uma fileira de plantas altas para as faixas de plantas normais. Nas parcelas, o plantio foi feito em covas espaçadas de $40 \mathrm{~cm}$, deixando-se três sementes em cada uma, para posteriormente, com as plantas em torno de $25 \mathrm{~cm}$ de altura, serem desbastadas, deixando-se duas plantas/cova, para uma densidade de 50.000 plantas/ha.

As adubações de plantio e cobertura e controle das plantas daninhas foram as normais para a cultura. Todos os dados lèvantados foram tomados na parcela como um todo ou de uma amostra representativa obtida de plantas competitivas den- 
tro da mesma.

Os caracteres levantados e a maneira de sua obtenção são apresentados descriminadamente a seguir:

- Número de dias para o florescimento masculino. Uma planta foi considerada florida quando em torno de $50 \%$ ou mais de suas espiguetas $j \vec{a}$ tivessem liberado polén, por avaliação visua1. Uma parcela fói considerada florida quando $50 \%$ ou mais de suas plantas fö̀sem consideradas floridas,através da contagem de plantas feitas a cada dois dias. 0 número de dias para o florescimento foi partanto o intervalo em dias do plan tio ao florescimento masculino.

- Intervalo entre florescimento "masculino e feminino. Uma p1an ta foi considerada florida quando os estilo-estigmas tinham pe1o menos'2 cm fora da palha. A parcela foi considera f1orida quando $50 \%$ ou mais de suas plantas jā tivessem emitido barba. 0 nümero de dias entre o florescimento masculino e feminino forneceu o respectivo: intervalo entre eles. Este dado foi obtido apenas em Piracicaba.

- Altura da planta. Cinco plantas competitivas foram tomadas ao acaso e medidas do solo até o ponto de inserção do 1 imbo foliar, da folha mais a1ta, no caule, isto é, no ponto de di visão entre 1 imbo e bainha foliar. Esta medida foi tomada após o florescimento, quando as plantas atingiram sua a1tura 
máxima. Os valores foram apresentados como altura em $\mathrm{cm}$.

- Altura da espiga. Esta medição foi feita também em cinco plan tas competitivas, tomadas aleatoriamente após o florescimento, sendo as mesmas plantas nas quais se avaliou a altura da planta. Os valores foram em $\mathrm{cm}$ do solo ao ponto de inser ção no caule da espiga mais a 1 ta da planta (a 1 a espiga).

- Indice AE/AP. Obtido dividindo-se a altura da espiga pela a 1tura' da planta, indica a posição da primeira espiga em re1 ação ao comprimento da planta. Um índice de 0,5 significa que a espiga está inserida na posição mediana do caule.

- Número de ramificações do pendão. Em apenas dois locais, Pi racicaba e Matão, se fez o levantamento deste dado. E a mé dia do número de ramificações do pendão contadas em cinco plantas competitivas amostradas aleatoriamente na fileira.

- Percentagem de plantas acamadas (raiz + colmo). 0 acamamen to neste caso refiere-se conjuntamente ao acamamento pela raiz e quebra do colmo. Sua avaliação foi feita através de conta gem de p1antas acamadas e quebradas na parcela e o resultado apresentado em sua percientagem em relação ao número total de plantàs .

- Percentagem de plantas acamadas. Refere-se ao número percen tual de plantas que não estando eretas, mostravam inclinação que pudesse comprometer os trabalhos de colheita,especialmen 
te mecânica.

- Percentagem de plantas quebradas. Neste caso o nümero de plantas quebradas abaixo das espigas foram contadas. Posteriormente calculou-se a sua percentagem em relação ao nümero total de plantas da parcela.

- Percentagem de espigas pendentes. Foi levantada pela conta gem do nümero de plantas com espigas pendentes em relação ao número total de plantas, dada em percentagem. Estecaracter foi tomado, apenas em Piracicaba.

- Densidade de plantas na parcela. Todas as plantas da parcela foram contadas por ocasião da colheita.

- Produção de grãos em kg/ha. Procedeu-se à colheita das espi gas de cada tratamento separadamente, as quais foram pesadas, imediatamente debulhadas, tomando-se o peso dos grãos e obten do-se uma amostra dos mesmos para determinação de sua umidade, conforme procedimento usuais. De posse destes dados, por meio de regra de três, calculou-sée a produção de grãos por parcela, corrigindo-se o seu valor para $0 \%$ de umidade e finalmente obteve-se a produção de grãos em kg/ha a $0 \%$ de umidade.

A correção da produção pela densidade de plantas obse $\underline{r}$ vada não foi feita pois no geral não melhoroư a eficiência das anā- 
1ises estatísticas para o referido ċáter. Em alguns casos contribuiu para aumentar os coeficientes de variação.

- Número médio de espigas por planta. Este dado foi obtido dividindo-se o número total de espigas colhidas pelo nümero de plantas total da parcela.

Para efeito de anāilise, os dados de percentágem de plantas acamadas $($ raiz + colmo), \% de plantas acamadas, \% de plantas quebradas, \% de espigas pendentes, número de dias para o florescimento masculino e intervalo entre o floresci mento mascuino e. feminin॰ foram - ajustados por $\sqrt{x+0,5}$ conforme sugerido por STEEL e TORRIE (1960). A análise da variância para todos os parâmetros obedeceu aos proce dimentos convencionais. Entretanto algumas considerações são necessārias para maior clareza.

Para a análise conjunta dos dados,: para...cada caracter, considerou-se um modelo misto, com o efeito de repetição dentro do local aleatório e os demais efeitos,local, por te e variedade, fixos. Em função disto, pela decomposição dos quadrados médios pode-se chegar à conclusão de que os valores de $F$ para os diferentes efeitos deveriam ser obtidos como a seguir: $0 F$ para o efeito de local foi obtido pela divisão de seu quadrado médio pelo de repetição/1ocal; o F para o efeito de porte e interaçäo porte x local pela divisão de seus res- 
pectivos quadrados médios pelo do resíduo $\boldsymbol{\alpha}$; o $F$ para o efeito de variedades'e interação de variedade $x$ local pela divisão dos seus respectivos quadrados médios pelo do resíduo b; o $F$ para as interações porte $x$ variedade e porte $x$ variedade $x$ local,pe la divisão de seus quadrados médios pelo do resíduo $c$.

0 desdobramento dos efeitos de porte e porte $x$ variedades em porte dentro de cada variedade implica no envolvimento dos resíduos a e $c$. Para se calcular os seus valores de $F$ é necessärio dividir-se os respectivos quadrados médios desdobrados por um quadrado médio calculado. Este foi obtido pe$1 a$ förmula: $\frac{Q M a+(v-1) Q M c}{v}$, onde tem-se o quadrado médio do resíduo a(QMa), o quadrado médio do resỉduo.c(QMc) e o número de variedades envolvidas (v). Como existem apenas porte alto e baixo a comparação de médias é dada automaticamente pelo tes te de $F$.

Também com relação aos efeitos desdobrados de variedades dentro de cada porte, o mesmo problema se apresenta, com o envolvimento dos resíduos $b$ e $c$. Os valores de $F$ dos efeitos desdobrados são obtidos pela divisão dos seus respecti vos quadrados médios por um quadrado médio calculado obtido pe fórmula: $\frac{Q M b+(p-1) Q M c}{P}$, onde tem-se o quadrado médio do resỉduo de portes ( $p$ ). A comparação de médias neste caso foi obtida pelo teste de Duncan a 5\% de probabilidade, conforme orienta- 
ção dada por PIMENTEl GOMES (1963) para comparações de médias de A em níveis de B em experimentos com parcelas subdivididas.

As förmulas para o cálculo dos quadrados médios envolvendo dois resíduos foram desenvolvidos teoricamente pelo Dr. Francisco Ivaldo 0 . Melo e nos comunicado pessoalmente. São também similares ao proposto por STEEL e TORRIE (1960) para com paração de médias de tratamento $A$ dentro de níveis de $B$, em de lineamento em 'split-plot' onde dois resỉduos são envolvidos à semelhança deste trabalho.

0 número de graus de liberdade para os quadrados médios calculados de dois resíduos foi ọtido pela fórmula de Satterthwaite, conforme sugerido por PIMENTEL GOMES (1963).

A análise conjunta para produção apresentou a dificuldade decorrentes de diferenças entre os residuos $a$, dos diferentes experimentos, acima do razoável (o maior sendo mais de quatro vezes o menor). A análise conjunta foi realizada tomando-se o cuidado de ajustar o grau de liberdade para o residuo $a$ onde a discrepância foi observada, segundo procedimento sugerido por PIMENTEL GOMES (1963).

Como no experimento de Piracicaba para alguns parâmetros não se considerou uma das repetições, os quadrados médios d̀os resíduos da análise conjunta foram médias ponderadas pelo número de repetições de cada experimento. 


\section{RESULTADOS E DISCUSSÃO}

4.1. Produção de Grãos

os resultados médios de produção de grãos encontram-se na Tabela 4 e os quadrados médios relativos à anali se da variância nas Tabelas 5 e $5 a$, no Apêndice. 0s coeficien tes de variação de $13,01 \%$ e $19,02 \%$ para as comparações entre populações e entre portes, respectivamente, demonstram satisfatória precisão do ensaio para esté parâmetro.

Em termos médios, as populações mostraram diferenças altamente significativas, tanto dentro de porte alto quan to do baixo. Houve boa concordância nas produtividades das populações tanto para porte normal como para o braquítico. Isto de certa forma era esperado uma vez que as duas populações ('VD $\left.{ }^{\prime} e^{\prime} V F_{3}{ }^{\prime}\right)$ não foram submetidos à seleção tão intensa quanto às demais. 
Para porte, entretanto, as braquíticas produzi ram em média aproximadamente como as normais, sendo a diferença ( $3,3 \%$ a menos) não significativa. A avaliação de porte. dentro de cada população demonstrou que nos três casos (VD ${ }_{2}^{\prime}$, VFí. 'e 'Maya') em que a forma braquítica passou por processos de seleção após a introdução do gene br-2, foram tão produti.vas quanto as normais na média dos locais estudados. Pelo que se pode observar da Tabela 4, elas produziram respectivamente $99,5 \%, 99,3 \%$ e $97,1 \%$ das altas. Quanto às duas populações não. selecionadas após a introdução do braquitismo, embora as diferenças entre porte dentro de cada uma não tenham sido significativas, apresentaram quadrados médios substancialmente maiores (Tabela 5a) que o observado para os demais casos. As produ ções foram de $94,6 \%$ e $91,9 \%$ das normais, respectivamente, dentro. das populações 'VD'. 4 ' e 'VF. 3'.

Pelos resultados observados, pode-se considerar que após a introdução do gene br-2, em populações, é recomendável efetuar seleção para produtividade, o que possibilita a obtenção de cultivares de porte baixo e alta produtividade. As melhores populações de porte baixo avaliadas mostraram-se tão produtivas quanto às a1tas. 0 milho 'Piranão VD. 2 ', por exemp1o, no local onde esteve relativamente pior, produziu apenas $2,7 \%$ a menos que a 'ESALQ VD. 2' e no $1 \bullet \mathrm{cal}$ ' onde foi melhor superou esta por $6,4 \%$, Deve-se considerar que este material ain da não sofreu seleção para produtividade, mas apenas para pro- 
lificidade, o que elevou seu potencial produtivo (PATERNIANI, 1980). O espaçamento adotado nos experimentos foi o usualmente empregado para as plantas normais e possivelmente,baseados na revisão da literatura, não.seja o mais indicado para as formas braquíticas.

Embora não tenha sido significativa a interação entre porte das planţas e local, pode-se observar um desem penho melhor das formas braquíticas em relação às normais nos locaïs de produção média menor, Guaíra (3.010 kg/ha) e Ituiuta ba $(3.463 \mathrm{~kg} / \mathrm{ha})$ onde produziram $98,4 \%$ e $105,0 \%$ das normais,respectivamente. Nos dois outros locais, de produção mais elevada, Piracicaba $(4.317 \mathrm{~kg} / \mathrm{ha})$ e Matão $(4.446 \mathrm{~kg} / \mathrm{ha})$ tiveram uma produtividade algo inferior com $92,5 \%$ e $93,3 \%$ das normais, res pectivamente. Possivelmente isto tenha decorrido como consequência de um maior desenvolvimento das plantas provocando efeito de sombreamento entre folhas da mesma planta ou de plantas vizinhas. A revisão de literatura, indica que as plantas suportam mais um aumento de densidade de plantas estreitando-se o espaçamento entre 1 inhas do que entre plantas dentro da linha. Neste último caso a consequência é um aumento acentuado de plantas estéreis e redução da produção (PENDLETon e SEIf, 1961). A melhoria das condições gerais de desenvolvimento da planta, que pode se refletir por níveis mais altos de produtivi dade, contribui para o aumento do indice de área foliar e consequente aumento do sombreamento entre plantas, o que, por ou- 
tro lado, afeta o potencial produtivo que poderia ser ainda maior.

Tem sido observada uma percentagem mais elevada de piantas estéreis nas formas braquíticas do que nas normais (GALVÃO e PATERNIANI, 1974, SINGH e RAI, 1979) e isto pode ser considerado como uma indicação de competição maior por luz en tre folhas de plantas diferentes ou da mesma planta. Nas plantas baixas este maior efeito do sombreamento de folhas pode ser esperado haja visto a maior proximidade das mesmas no plano vertical e sua maior largura. Estas considerações são in teressantes pois fornecem subsídios para que se possa sugerir um melhoramento das populações braquitizadas mais. no senti. do de contornar o problema de competição por luz entre folhas da planta e entre plantas vizinhas, do que para produção propriamente dito. Dada a alta herdabilidade das características da planta que possam permitir maior penetração da 1 uz na sua folhagem, é possível que a seleção para esses caracteres conduza a maior progresso para a produção de grãos do que a seleção para este caráter.

Uma planta que permita maior distribuição de 1 uz pelas suas folhas, permitirà às populações braquíticas plantios em densidades mais elevadas contribuindo assimpara o aumento do potencial produtivo.

As características a que se estā referindo se- 
riam: folhas mais, eretas, mais estreitas, saindo dos sucessivos nós em direções diferentes, pendões menores, maior distân cia vertical entre folhas ao longo do caule e menor número de folhas nas plantas muito enfolhadas.

Como se tem sugerido que nos milhos tropicais o depósito é o mais limitante, a diminuição do número de folhas não deve acarretar grandes problemas podendo, no caso dos braquíticos ser até benéfica. Ao se sugerir a seleção para tais características não significa que todas elas devam ser introduzidas concomitantemente, mas que precisam ser consideradas no programa de melhoraménto. Deve-se ressaltar que a simples introdução dessas características, não significa necessariamente êxito, mas deve-se ter o cuidado de introduzi-las em populações onde possam ser recombinadas, e uma situação de harmọia entre os caracteres, possa ser buscada por seleção, para uma condição de maior produção.

As plantas braquíticas de milho são vistas neste trabalho como um meio de situar o potencial produtivo da cul tura em um patamar mais elevado do que o das plantas tradicionais. Os estudos com as plantas braquíticas devem continuar, inclusive procurando-se esclarecer as relações do braquitismo com as demais características da planta, especialmente com aquelas relacionadas; a uma maior eficiência da mesma, na utili zação dos fatores de seu ambiente e conversão dos mesmos em pro 
dução de grãos.

\subsection{Acamamento}

Para este parâmetro realizou-se três análises, sendo uma para o acamamento total e outras duas paraos efeitos parciais de acamamento de raiz e quebra de colmo. De uma forma geral os coeficientes de variação foram altos para as três anālises, especialmente para o acamamento de raiz, tanto para a avaliação de porte quanto de populações, conforme podé-se observar nas Tabelas 5 e 7 . Apesar disto o efeito de porte foi altamente significativo em todas elas e sua interação com local mostrou também diferenças significativas. 0 efeito de populações foi significativo apenas, para acamamento de raiz, o que foi explicado prinçipalmente pelas diferenças dentro de porte alto ( $\dot{T}$ abelas 7 e 7a). As médias dos valores observados de acamamento encontram-se nas Tabelas 4 e 6 . 0 acamamento (raiz e col mo) foi em média de $11,8 \%$ nas formas braquíticas e de $33,4 \%$ nas plantas normais, representando aquele valor $35,3 \%$ deste, isto é, uma redução de aproximadamente $65 \%$ do acamamento, nas formas baixas. A literatura tem noticiado uma ampla variação para o efeito do braquitismo sobre o acamamento, desde reduções de $100 \%$ do acamamento quando todas as plantas altas tomba ram (LENG, 1957), a uma redução de apenas $30 \%$ ou menos (SINGH e RAI, 1979). Estas variações são perfeitamente justificáveis, 
inclusive pelos dados deste trabalho, uma vez que o porte interagiu tanto com local como com populações, o que significa dizer que a redução do acamamento pelo braquitismo não é a mes ma em todos os locais nem para todas as populações. Em Guaíra e Piracicaba, por exemplo, o acamamento (raiz e colmo) dos mi Thos braquiticos representou $26 \%$ e $44 \%$ do observado nas normais, respectivamente. Na população 'VD4' a forma braquítica promoveu uma redução do ácamamento.(raiz + colmo) para $26 \%$ do normal; enquanto que na 'VF.1' esta foi para $42 \%$ do normal, ha vendo, neste caso uma menor redução. Com relação ao acamamento de raiz e quebra de colmo, os resultados da anālise estatística foram muito similares aos observados, para o acamamento $($ raiz + colmo), no que diz respeito aos efeitos significativos (Tabela 7). As diferenças entre populações foram significatí vas apenas para acamento de raiz e pelo que se pode observar na Tabela 6, esta diferença ocorreu na média dos dois portes, distinguindo-se a população 'Maya' com menor acamamento de raiz.

Outro aspecto a salientar é que a redução do acamento tanto do ponto de vista da quebra do colmo quanto da raiz, foi igualmente influenciado pelas formas braquíticas. 0 acamamento de raiz e quebra de colmo nas braquíticas foi $34,0 \%$ e 35,7\% do observado nas normais. ANDERSON e CHOW (1963), BULOW (1971) e PATERNIANI (1980) observaram haver menor quebra dos colmos do que acamamento de raiz nas braquíticas. Piracicaba, foi o único lugar onde isto foi observado. Em média dos qua- 
tro locais, a quebra do colmo representou em torno do dobro do acamamento de raiz e possivelmente os fatores responsāieis por estes níveis altos de quebra de colmo tenham influenciado igual mente as formas braquiticas.

Resumindo as considerações feitas, pode-se dizer que para as condições brasileiras as formas braquíticas représentam uma vantagem real em relação aos tipos altos, ao produ zirem tanto quanto éstes e por acamarem muito menos.

o acamamento que se tem observado nos milhos de porte alto, representa um risco adicional à sua cultura, pelas dificuldades na colheita e perdas que acarreta, fazendo com que esta característica seja de grande prioridade no melhoramento. Considerando ainda o processo de tecnificação qué ocorre com a agricultura no País, envolvendo necessariamente o milho, em especial do ponto de vista da colheita mecânica, a resistência ao acamamento é fundamental, uma vez que a máquina não cole ta espigas caídas.

4.3. Altura da Planta, da Espiga e Indice AE/AP

Um dos principais efeitos do gene br-2 é a redu ção do comprimento dos internódios da planta,sendo sua consequência direta a diminuição da altura da planta e da espiga. os 
trabalhos de vários autores têm demónstrado, com clareza, este efeito (Tabela 1 e 2), o mesmo ocorrendo com os resultados obti dos no presente trabalho.

Nas Tabelas 9," 9a, 11 e 11 a encontram-se os resumos das anālises da variância e os respectivos coeficientes de variação para altura da plantas, altura das espigas e índice $\mathrm{AE} / \mathrm{AP}$.

Peloque se pode observar foram obtidos efeitos significativos tanto para altura da planta ... como para a altur. ra da espiga. Em ambos os casos houveram efeitos altamente significativos para porte, interação porte $x$ local e porte $x$ po puilação, para população e também para a interação tripla por te $x$ local x população, indicando que a interação porte $x$ 1ocal não foi uniforme para as diferentes populações. Os coefi cientes de variação foram satisfatórios para os caracteres em questão. A Tabela 8 apresenta as médias de altura da planta e altura da espiga e como se pode notar,as populações de grãos duros 'VF.1' 'VF.3' apresentaram-se de porte mais baixo e também com menor altura de espiga dentro de porte normal. Den tro das braquíticas houve também diferenças entre as populações para altura da planta, sendo a 'VD. ' $^{\prime}$ e 'VF. ' $^{\prime}$ de maior e me nor altura de espiga, respectivamente. Com relação à altura da planta e da espiga as braquiticas apresentaram valores mais baixos com diferenças altamente significativas, sendo em média $69,0 \%$ e $58,4 \%$ das normais, respectivamente, para as duas caracte 
rísticas consideradas.

o braquitismo não reduziu o porte e altura da espiga nas mesmas proporções nos diferentes locais. A maior re dução ocorreu em Matão com $78,3 \%$ e $63,3 \%$ da altura dos normais e a menor em Guaíra com $59,5 \%$ e $50,9 \%$ das normais, respectivamente para altura da planta e da espiga. A interação én tre porte e populações significa que para as populações estuda das, o efeito do caráter braquítico não foi uniforme entre elas, tanto para altura da planta quanto da espiga. Na população 'Maya' ocorreram as maiores reduções em altura,especialmente da espiga, salientando-se ainda que foi a população normal de plan ta e espiga mais a 1 tas (Tabela 8 ).

0 indice AE/AP reflete a posição relativa da primeira espiga no caule e os dados da literatura (Tabela 1 e 2) sugerem quie as formas braquíticas, por terem os entrenós abaixo da primeira espiga reduzidos mais intensamente em comprimento que os acima, têm a espiga relativamente mais baixa no caule, isto é, um indice $A E / A P$ menor. Os resultados da ana lise da variância a este respeito são apresentados na Tabela 11 tendo sido encontrados efeitos altamente significativos para porte, populações e interações porte $x$ local, porte $x$ populações e porte x população x local.

A Tabela 10 trás os resultados médios do indice AE/AP. As plantas braquíticas tiveram a esplga relativamente 
mais baixa no caule do que as plantas altas,com sua posição ao comprimento do caule $15,9 \%$ mais baixa que a das plantas normais. 0 índice AE/AP foi também menor para as braquíticas den tro de todas as populações estudadas. Entretanto sua redução ñão foi uniforme entre elas, dada a interação porte x variedade observada. Esta interação não teve as mesmas proporções nos diferentes locais, visto a interação porte $x$ população x local significativa.

Entre as plantas normais, as populações de grãos duros 'VF.1' e 'VF.3' apresentaram menor indice AE/AP ocorrendo o maior valor na população 'Maya'; por outro lado, nas braquíticas, a população Maya apresentou o menor indice e a 'VD. 2' o maior.

A altura da planta tem sido relacionada a uma maior resistência a acamamento o que, aliado a uma posição da espiga relativamente mais baixa no caule acrescenta maior resistência. Do ponto de vista do melhoramento de plantas não ha vendo tanta necessidade de se selecionar para altura de planta e de espiga, o esforço pode ser concentrado para a obtenção de ganhos em produção com maior chance dè êxito.

4.4. Nümero de Espigas por Plantas

os résultados da anālise da variância para es- 
ta característica são apresentados nas Tabelas 11 e 11 a. Apenas os efeitos de locais e populações foram significativos,bem como o efeito de variedades dentro de cada porte. os coeficien tes de variação foram satisfatórios.

A população 'VF.1' apresentou o maior número de espigas por planta tanto no porte baixo como alto, e a 'VD.4'" For outro lado o menor número (Tabela 10). Entre as plantas braquíticas a 'VD. $2^{\prime}$ apresentou-se tão prolifica como a $' V F .1 '$.

A ausência de significância para o efeito de por te é interessante porque é uma indicação de que a presença do gene br-2 pode não afetar a prolificidade das plantas como ocoreu para as populaçöes deste trabalho. Como a prolificidade é uma característica importante,pois tem sido associada a aumen tos da produtividade e da estabilidade de produção (HALlaUER e TROYER,1972) o fato de não ser incompatível com plantas braquí ticas é positivo pois estas podem ser selecionadas para tal, ga nhando em desempenho, como demonstrado por PATERNIANI (1980).

o desdobramento do efeito de porte dentro de po pulações' mostrou para a 'VD. $2^{\prime}$ um efeito significativo, com o seu quadrado médio mais de dez vezes superior aos encontrados para porte dentro das demais variedades (Tabela 11a). Isto explica-se pelo fato da população 'Piranão VD.2' ter passado por quatro ciclos de seleção massal para prolifici- 
dade. A Piranão VF.1' também o foi, porèm neste trabalho não mostrou ganhos.

\subsection{Florescimento}

Os resultados da análise da variância para o nü mero de dias para o florescimento masculino,em dois locais, e o intervalo entre o florescimento masculino e feminino, em um 1 o cal, encontram-se na Tabela 13 e 13a. Com relação ao nümero de dias para o florescimento masculino encontraram-se diferenças altamente significativas para os efeitos de local, populações e interação porte $x$ populações e. significativa para a interaçao populaçoes x local. Os coeficientes de variação estiveram em torno de $1 \%$ (Tabela 13 ).

os resultados médios obtidos encontram-se na Ta bela 12 e como se pode notar a diferença em termos médios foi muito pequena e não significativa entre os portes. Entre popu1 ações, na média dos dois portes, houve diferenças significativas, com as populações 'VF.1' e 'VF. ' $^{\prime}$, ambas de grãos duros, mostrando-se mais precoces que as demais. O desdobramento do efeito de populações dentro de cada porte mostrou diferenças tambēm significativas, como se pode observar nas Tabelas 12 e 13a. As populações não se comportaram uniformemente nos dife rentes locais, pois interagiram com eles, tendo o porte um 
efeito consistente nos dois locais. A. interação altamente significativa de porte $x$ populações mostrou que o braquitismo provocou mudanças de magnitudes e até mesmo sentido diferentes nas populações, com relação à precocidade de florescimento masculino. Como exemplo, pode-se citar a população 'VF ${ }_{1}^{\prime}$ que foi significativamente mais tardia em mëdia 2,4 dias e a 'Maýa' que tornou-se mais precoce em 1,8 dias. Estes resultados sugerem que a discordância a este respeito pela literatura pode ser função dos germoplasmas estudados. CIMMYT (1972) e SINGH e RAY (1979) não observaram mudanças no número de dias para a floração com a introdução do gene br-2, entretanto ANDERSon e CHOW (1963) observaram que hỉbridos braquíticos ficaram um a três dias mais tardios.

Com relação ao intervalo entre o florescimento masculino e feminino,os dados referem-se unicamente aos obti dos em Piracicaba. A análise da variância (Tabelas 13 e 13a) mostrou efeito significativo apenas para porte dentro da varie dade VD.2 e entre variedades dentro de porte baixo. Deve-se ressaltar que os coeficientes de variação para comparação. de portes $(12,5 \%)$ e de variedades $(22,71 \%)$ podem ser considerados relativamente elevados.

Embora não se tenham observado diferenças entre tratamentos, chama a atenção a redução do intervalo entre o florescimento masculino e feminino encontrada na 
população 'VD. 2' para a forma braquítica em relação à normal (Tabela 12), o que também deve explicar as diferenças entre va riedades de porte baixo.

Como os resultados são de apenas um local e cin co populações, a anālise da variância talvez não tenha tido sensibilidade suficiente para detectar as diferenças entre os tratamentos e mais estudos seriam oportunos a este respeito. De qualquer maneira, como nos milhos braquíticos não foram obtidas diferenças significativas para o intervalo entre florescimento masculino e feminino bem como para o número de espi gas por planta, pode-se concluir que, nas braquíticas, a dominân cia apical não deve ser menor.

4.6. Nūmero de Ramificações do. Pendão

Qs resultados da anālise da variância encontram-se nas Tabelas 15 e $15 \mathrm{a}$. Os coeficientes de variação relativamente baixos refletem uma precisão razoável dos ensaios. Foram encontradas diferenças altamente significativas para os efeitos de locais,por te, populações (tanto dentro de porte normal quanto braquítico) e interação porte $x$ populações. Diferenças significativas também foram mostradas :pelo porte dentro da maioria das populações (Tabela 15a). Os resultados médios de número de ramificações do pendão são apresentados na Tabela 14. Pode-se verificar que 
as populações 'VF.1' e 'VF. 3', ambas de grãos duros, apre+ sentaram os maiores pendões, tanto no porte normal quanto no braquítico, enquanto a 'VD. 2' e 'Maya' tiveram os menores valores. O tamanho do pendão nas formas braquíticas foi em mëdia $10,7 \%$ menor que nas normais. Entretanto, a redução do tamanho do pendão não foi da mesma magnitude nos diferentes materiais. Na população 'VF.1', a redução do tamanho do pendão não foi significativa, ficando a $97,2 \%$ da forma normal, porēm nas demais foi altamente significativa (Tabelas 1.4 e 15 a).

A redução em média de $10,7 \%$ no tamanho do pendão das formas braquíticas em relação aos tipos convencionais deste ensaio, embora não sendo grande é uma qualidade adicio nal que se ganha pela. introdução do gene br-2, embora isto pos sa não ocorrer em todos os genótipos. Tem sido constatada uma alta correlação negativa entre tamanho do pendão e prolifici dade (SOUZA Jr. et alii, 1981) e poderia se esperar um concomi tante aumento do número de espigas por planta com redução do pendão. Entretanto, isto não ocorreu, possivelmente devido à pequena diminuição do pendão, e também porque a precisão do en saio foi insuficiente para detectar ganhos em prolificidade $(2,1 \%)$.

A obtenção de plantas baixas de pendões pequenos seria muito interessante como um meio de diminuir o efeito 
de sombreamento e da dominância apical, tornando as plantas mais eficientes e de produção maior e mais estável.

\subsection{Espigas Pendentes}

Os resultados da anāilise da variância encon tram-se nas Tabelas 15 e $15 a$ e mostram que diferenças altamente dignificativas para o carāter foram obtidas para o efeito de porte, na média geral e dentro de cada população. Os coef cientes de variação foram relativamente altos.

os resultados médios de porcentagem de espigas pendentes são apresentados na Tabela 14. As populações apresentaram em média. $32,1 \%$ e $14,8 \%$ de espigas pendentes nas formas normais e braquíticas, respectivamente.

Espigas com pedúnculo longo são mais propensas a serem pendentes, uma vez que maior será a força exercida pe1a espiga, devido a seu peso. A menor frequência de espigas pendentes nas formas braquíticas ( $46,1 \%$ das normais) deve ter ocorrido em função do encurtamento dos entrenós do pedúnculo da espiga. O encurtamento dos entrenós do pedúnculo è uma suposição que necessita de comprovação experimental. 
A espiga pendente apresenta a vantagem de maior proteção dos grãos contra umidade e as doenças. Entretanto havendo bom empalhamento a proteção da espiga $\bar{\epsilon}$ bastante satisfatória. 
5. CONCLUSÕES

1. As populações de milho braquíticos foram tão produtivas quanto às correspondentes de porte normal. E'm ordem decrescente as populações se classificaram como segue: 'Piranão VD. 2', 'Mayanão II' e 'Piranão VF. 1', cujas produções em relação às normais foram: $99,5 \%, 97,1 \%$ e $99,3 \%$, respectivamente.

2. O acamamento de plantas das populações braquíticas correspondeu a $35,3 \%$ dos valores apresentados pelos milhos. normais, ocorrendo reduções similares para o quebramento do colmo e acamamento da raiz.

3. As formas braquíticas com altura média da planta de $169,8 \mathrm{~cm}$ e altura média da éspiga de $90^{\circ}, 8 \mathrm{~cm}$ foram res pectivamente, $31,0 \%$ e $41,6 \%$ mais baixas do que as correspondentes normais.

- 4. A posição relativa da espiga foi mais baixa nos milhos braquíticos. O indice.AE/AP foi de 0,53 e 0,63 pa 
ra os milhos braquíticos e normais, respectivamente.

5. Não houve diferença, em termos médios, para - ofeito de porte, quanto ao número de espigas por planta.

6. O número de dias para o florescimento mascuIino, ao redor de 75 dias, foi similar para os milhos braquiti cos e para os normais. Tambëm o intervalo entre o florescimento masculino e feminino, ao redor de 2,6 dias foi semelhante para os dois grupos.

7. As populações braquíticas apresentaram em mé dia menor nümero de ramificações do pendão $(89,3 \%$ em re 1 ação àsinormais). As populaçôes 'VF.1' e 'VF. ' $^{\prime}$, ambas de grãos duros apresentaram os maiores pendões nos dois portes de planta. Em uma das populações ('Maya') a forma braquítica.teve o pendão maior que a normal, ao conträrio das demais .

8. As populações braquítiças apresentaram uma proporção menor de espigas pendentes com $46,1 \%$ do valor obtido nos milhos normais.

Em vista dos resultados apresentados pela popu1 ações braquíticas, pode-se concluir finalmente que elas são viāveis para as condições brasileiras. 0 procedimento de redu ção do porte de plantas pela introdução do gene br-2, em populações, 


\section{LITERATURA CITADA}

ALLISON, J.C.S. e D.J. WATSON, 1966. The production and distribution of dry matter in maize after flowering. Annals of Botany. Londres, 30:365-381.

ANDERSON, J.C. e P.N. CHOW, 1963. Phenotypes and grain yield associated with brachytic- 2 gene in single - cross hybrids of dent corn. Crop Science. Madison, 3:111-3.

ANDERSON, I.C., 1967. Plant characteristics that affect yield. Proceedings of the $22^{\text {th }}$ Annual Hybrid Corn Industry-Research Conference. Washington, 22:71-73.

ANDRADE, J.A.C. e J.B. MIRANDA FILHO, 1979. Estimativas de parâmetros genëticos para os caracteres do pendão na população 'ESALQ-PB1!' de milho. Relatörio Cientifico do Instituto de Genética - ESALQ/USP. Piracicaba, 13:15-21. 
ARIYANAYAGAM, R.P., C.L. MOORE e V.R. CARANGAL, 1974. Selection for leaf angle in maize and its effects on grain yield and other. characters. Crop Science. Madison, 14:551-556.

BANDEL, G., 1978. Genética. In: PATERNIANI, E., Coord. Melho ramento e Produção do Milho no Brasil. Piracicaba, Marprint, p.97-121.

BROWN, W.L., 1965. Physical characteristics of corn of the future. Proceedings of the $20^{\text {th }}$ Annual Hybrid corn Industry - Research Conference. Washington, 20:7-16.

BüLoW, J.F.W., 1971. Efeitos do gen braquítico- 2 em populações anālogas em híbrido de milho (Zea mays L.). Pesquisa Agropecuáxia Brasileira. Rio de Janeiro, 6:155-161.

BUREN, L.L., J.J. MOCK e I.C. ANDERSON, 1974. Morphologica1 and physiological traits in maize associated with tolerance to high plant density. Crop Science. Madison, 14:426-429.

CAMPBELL, C.M., 1965. New dwarfs and modifiers. Proceedings of the $20^{\text {th }}$ Annual Hybrid Corn Industry - research Conference. Washington, 20:22-29.

CHASE; S.S. e K.K. NANDA, 1967. Number of leaves and maturity classification in Zea mays L. Crop Science. Madison, $7: 431-432$. 
CHINWUBA, P.M., C.0. e M.S. ZUBER, 1961. Interation of detasseling, sterility, and spacing on yields of maize hybrids. Crop Science. Madison, 1:279-280.

CIMмYT, 1972. Maiz-Mejoramiento Genético. Informe Anual del CIMMYT. p.94-102.

COLLINS, W.C., W.A. RUSSEll e S.A. EBERHART, 1965. Performance of Twoear type of corn belt maize. Crop Science. Madison, . 113-116.

CROPS and SOILS, 1960. What is the future role of dwarf corn? Crops and Soils. Madison, 12:9-11.

CROSBIE, T.M., 1977. Variability and selection advances for photosynthesis in Iowa Stiff Stalk Synthetic maize population. Crop Science. Madison, 17:511-514.

CROSBIE, T.M., 1981. Recurrent phenotypic selection for high and low photosynthesis in two maize populations. Crop Science. Madison, 21:736-740.

CROSBIE; T.M. e J.J. MOCK, 1981. Changes in physiological traits associated with grain yield improvement in three maize breeding programs. Crop Science. Madison, $21: 255-259$. 
CROSS, H.Z., 1975. Diallel analysis of duration and rate of grain filling of seven inbreed lines of corn. Crop Science. Madison, $15: 532-535$.

DATA, S.K., A.C. TAURO e S.N. BALADING, 1968. Effect of plant type and nitrogen level on the growth characteristiçs and grain yield of Indica rice in the tropics. Crop Science. Madison, 60:643-647.

DAYNARD, T.B., J.W. TANNER e D.J.HUME, 1969. Contribution of stalk soluble carbohydrates to grain yield in corn /Zea mays L.1. Crop Science. Madison, 9:831-834.

DAYNARD, T.B., J.W. TANNER e W.G. DUNCAN, 1971. Duration of the grain filling period and its relation to grain yield in corn, Zea mays L. Crop Science. Madison, 11:45-48.

DAYNARD, T.B. e L.W. KANNENBERG, 1976. Relationships between lenght of the actual and effective grain filing periods and the grain yield of corn. Canadian Journal of Plant Science. 0ttawa, $56: 237-242$.

DENMEAD, 0.T., L.J. FRITSCHEN e R.H. SHAW, 1962. Spatia1 distribution of net radiation in a corn field. Agronomy Journal. Madison, 54:505-510. 
DONALD, C.M., 1968. The breeding of crop ideotypes. Euphytica. Wageningen, 17:385-403.

DUNCAN, W.G., A.L. HATFIELD e J.L. RAGLAND, 1965. The growth and yie1d of corn. II. Dayly growth of corn kernels. Agronomy Journal. Madison, 57:221-223.

DUNCAN, W.G., W.A. WILLIAMS e R.S. LOOMIS, 1967. Tasse 1s. and the productivity of maize. Crop Science. Madison, 7:37-39.

DUNCAN, W.G. e J.D. HESKETH, 1968. Net photosynthetic rates, relative leaf growth rates, and leaf numbers of 22 races of maize at eight temperatures. Crop Science. Madison, $8: 670-677$.

DUNCAN, W.G., 1971. Leaf angles, leaf area, and canopy photosynthesis. Crop Science. Madison, 11:482-485.

DUNCAN, W.G., 1972. Plant spacing, density, orientation, and light relationships as related to different corn genotypes. Proceedings of the $27^{\text {th }}$ Annual Corn and Sorghum Research Conference. Washington, 27:159-166.

DUVICK, D.N., 1958. Yield and other agronomic characteristics of cytoplasmically pollen sterile corn hybrids, compared to their normal counterparts. Agronomy Journal. Madison, $50: 121-125$ 
DUVICK, D.N., 1974. Continuous backcrossing to transfer prolificacy to a single-eared inbred line of maize. Crop Science. Madison, 14:69-71.

EARLEY, E.B., R.J. MILLER, G.L. REICHERT, R.H. HAGEMAN E.R.D. - SEIF, 1966. Effect of shade on maize production under. fields conditions. Crop Science. Madison, 6:1-7.

EARLEY, E.B., W.O. MCILRATH, R.D. SEIF e R.H. HAGEMAN, 1967. Effects of shade applied at different stages of plant development on corn (Zea mays L.) production. Crop Science. Madison, $7: 151-156$.

EASTIN, J.A., 1969. Leaf position, and leaf function in corn-carbon-14 1abeled photosynthate distribution in corn in relation to leaf position and leaf function. Proceedings of the $24^{\text {th }}$ Annual Corn and Sorghum Research Conference. Washington, $24: 81-89$.

EIK, K. e HANWAY, J.J., 1965. Some factors affecting development and longevity of leaves of corn. Agronomy Journal. Madison, 57:7-12.

EIK, K. e HANWAY, J.J., 1966. Leaf area in relation to yield of corn grain. Agronomy Journal. Madison, 58:16-18. 
EVANS, L.T. e I.F. WARDLAW, 1976. Aspects of the comparative physiology of grain yield in cereals. Advances in Agronọy. New York, 28:301-351.

FILIPPOV, G.L. e N.V. VISHNEVSKII, 1982.'Basis of an ecological and physiological model for a drought-resistant maize hybrid. Plant Breeding Abstract. Londres, 52:263.

GALVÃO, J.D. e E. PATERNIANI, 1974: Comportamento do milho 'Piranão' (braquítico-2) e de milhos de porte normal em diferentes níveis de nitrogênio e populações de plantas. Tese de Doutoramento - ESALQ/USP. Piracicaba, 106p.

GROGAN, C.0., 1956. Detasseling responses in corn. Agronomy Journal. Madison, 48:247-249.

HALlAUER, A. R. A.F. TROYER, 1972. Prolific corn hybrids and minimizing risk of stress. Proceedings of the $27^{\text {th }}$. Annual Corn and Sorghum Research Conference. Washington, $27: 140-158$.

HANWAY, J.J., 1962. Corn growth and composition in relation to soil fertility: I. Growth of different plant parts and relation between leaf weigt and grain yield. Agronomy Journal. Madison, 54:145-148. 
HANWAY, J.J., 1963. Growth stages of corn (Zea mays L.). Agronomy Journal. Madison, 55:487-491.

HANWAY, J.J. e W.A. RUSSELL, 1969. Dry-matter acumulation in corn (Zea mays L.l plants: Comparisons among single-cross hybrids. Agronomy Journal. Madison, 61:947-951.

HEICHEL, G.H. e R.B. MUSGRAVE, 1969. Varietal differences in net photosynthesis of Zea mays L. Crop Science. Madison, $9: 483-486$.

HESKETH, J.D. e R.B. MUSGRAVE, 1962. Photosynthesis under field conditions. IV. Light studies with individual corn 1eaves. Crop Science. Madison, 2:311-315.

HICKS, D.R. e R.E. STUCKER, 1972. P1ant density effect on grain yield of corn hybrids diverse in leaf orientation. Agronomy Journal. Madison, 64:484-487.

HOYT, P. e R. BRADFIELD, 1962. Effect of varying leaf by partial defoliation and plant density on dry matter prodution in corn. Agronomy Journal. Madison, 54:523-525.

HUNTER, R.B., T.B. DAYNARD, D.J. HUME, J.W. TANNER, J.D. CURTIS, e L.W. KANNENBERG, 1969. Effect of tassel removal on grain yie1d of corn (Zéa mays L.). Crop Science. Madison, $9: 405-406$. 
HUNTER, R.B., 1980. Increased leaf area (source) and yield of maize in short-scason areas. Crop Science. Madison, $20: 571-574$

IRRI, 1966. Growth and yield. The IRRI Reporter. Manila, $2: 1-3$.

JENNINGS, P.R., 1964. Plant type as a rice breeding objective. Crop Science. Madison, 4:13-15.

JENNINGS, P.R., 1966. The evolution. of plant type in Oryza sativa L. Economic Botany. Bronx, 20:369-402.

JOHNSON, R.R.; K.E. MCCLURE, L.J. JOHNSON, E.W. KLOSTERMAN e G.B. TRIPLETT, 1966. Corn plant maturity. I- Changes in. dry matter and protein distribution in corn plants. Agronomy Journal. 'Madison, 58:151-153.

JOHNSON, D.R. e J.W. TANNER, 1972. Calculation of the rate and duration of grain filling in corn (zea mays L.). Crop Science. Madison, 12:485-486.

KATTA, Y.S. e M.C. GIL, 1970. Some reasons for depressed yie1d in dwarf corns. Maize Genétics Cooperation News Letter. Co1umbia, $44: 24-25$. 
KEMPTON, J.H., 1920. Heritable characters of maize. III. brachytic culms. Journal of Heredity. Washington, $11: 111-115$.

KHERA, A.S.; V.V. MALHOTRA, V.K. SAXENA e B.S. DHILLON, 1975. Role of brachytic-2 in genetic improvment of maize. Egyptian Journal of Genetics and Cytology. Alexandria, $4: 430-2$.

LAMBERT, R.J., 1963. Location of brachytic-2 dwarf. Maize Genetics Cooperation News Letter. Columbia, 37:41-42.

LAMBERT, R.J., 1971. Corn plant geometry and the performance of maize hybrids. Proceedings of the $26^{\text {th }}$ Hybrid Corn Industry-Research Conference. Washington, 26:193-197.

LAMBERT, R.'J. e R.R.JJOHNSON, 1978. Leaf angle, tansel morphology, and the performance of maize hybrids. Crop Science. Madison, 18:499-502.

LAWLOR, D.W., 1979. Effects of water and heat stress on carbon metabolism of plants with $\mathrm{C}_{3}$ and $\mathrm{C}_{4}$ photosynthesis. In: MUSSELL, H. e R.C. STAPLES. Stress Physiology in Crop Plants. New York, Wiley Interscience, p.303-326. 
LEITE, D.R. e E. PATERnIANI, 1973. "Comportamento de milho (Zea mays L.) braquítico-2 em diferentes densidades de plantio. Relatório Cientifico do Instituto de Genética, ESALQ/USP. Piracicaba, 7:74-82.

LENG, E.R. e M.L. VINEYARD, 1951. Dwarf and short plants. Maize Genetics Cooperation News Letter. Columbia, 25:31-32.

LENG, E.L., 1957. Genetic production of short stalked hybrids. Proceedings of the $12^{\text {th }}$ Annual Hybrid Corn Industry-Research Conference. Washington, 12:81-87.

LOOMIS, R.S. e W.A. WILlIAMS, 1963. Maximum Crop Productivity: An Estimate. Crop Science. Madison, 3:67-72.

MACKINNON, J.C., 1979. Energy allocation during growth of six maize hybrids in Nova Scotia. Canadian Journal of Plant Science. Ottawa, 59:667-677.

MAGALHÃES, A.C. e W.J. SILVA, 1978. Determinantes genético-fisiológicos da produtividade do milho. In: PATERnIANI, E., Coord. Melhoramento e producão do milho no Brasil. Piracicaba, Marprint, p.349-375.

MAGALHÃES, A.C.N., 1979. Anālise quantitativa do crescimento. In: FERRI, M.G., Coord. Fisiologia Vegetal. São Paulo, EPU, P. 331-313. 
MOCK, J.J. e R.B. PEARCE, 1975. An ideotype of maize. Euphytica. Wageningen, 24:613-623.

MOSS, D.N.; R.B. MUSGRAVE e E.R. LEMON, 1961. Photosynthesis under field conditions. III. Some effects o light, carbon dioxide, temperature, and soil moisture on photosynthesis, respiration, and transpiration of corn. Crop Science. Madison, $1: 83-87$.

MosS, D.N., 1962. The limiting carbon dioxide concentration for photosynthesis. Nature. Basingstoke, 193:587.

MosS, D.N., 1964. Optimum 1ighting of leaves. Crop Science. Madison, 4:131-136.

MOSS, D.N. e D.E. PEASLEE, 1965. Photosynthesis of maize leaves as affected by age and nutrient status. Crop Science. Madison, $5: 280-281$.

MUSGRAVE, R.B., 1971. Photosynthetic efficiency in corn. Proceedings of the $26^{\text {th }}$ Annual Corn and Sorghum Research Conference. Washington, 26:186-191.

NASYROV; Y.S., 1978. Genetic control of photosyntesis and improving of crop productivity. Annual Review of Plant Physiology. Paló Alto, 29:215-237. 
NORCIO, N.V. e E.B. PANTASTIC0, 1973. The effect of nitrogen and stage of growth on photosynthesis rates of some lowland rice varieties. The Philippine Agriculturist. Los Baños, 52:116-127.

NUNEZ, R. e E. KAMPRATH, 1969. Rationship between N response, plant population and row width on growth and yield of corn. Agronomy Journal. Madison, 61:279-282.

PARIS, C.G., 1980. Impacto de 1 as nuevas variedades de arroz en el desarrollo de1 cultivo. Arroz. Bogotá, 29:24-25.

PATERNIANI, E., 1971. Comportamento de milhos de porte baixo em duas densidades de plantio. Rezatório Científico do Instituto de Genética-ESALQ/USP, Piracicaba, 5:133-135.

PATERNIANI, E., 1974. Seleção entre e dentro de famîlias de meios irmãos no milho Piranão. Relatôrio Científico do Instituto de Genética - ESALQ/USP. Piracicaba, 6:174-9.

PATERNIANI, E., J.R, ZINSLY e J,B, MIRANDA FILHO, 1977. Populações melhoradas de milho obtidas pelo Instituto de Genétí ca. Relatório Cientifico do Instituto de Genética, ESALQ/USP. Piracicaba, 11:108-114. 
PATERNIANI, E., 1980a. Seleção massal com controle biparental para prolificidade em milho. Relatório Cientifico do Instí tuto de Genética - ESALQ/USP. Piracicaba, 14:69-76.

PATERNIANI, E., 1980b. Avaliação de cultivares de milhos braquíticos. Relatório Cientifico do Instituto de Genética - ESALQ/USP. Piracicaba, 14:61-68.

PATERNIANI, E., 1981a. Influence of tassel size on ear placement in maize (Zea mays L.). Maydica. Bergamo, $26: 85-91$.

PATERNIANI, E., 1981b. O tamanho do pendão e suas relações com o. Indice altura de espiga/altura de planta e com a produtivi dade no Ensaio Nacional de Milho Normal. Relatório Científí co do Instituto de Genética - ESALQ/USP. Piracicaba, 15:135-151:

PEASLEE, D.E.; J.L. RAGLAND e W.G. DUNCAN, 1971. Grain fil1ing period of corn as influenced by phosphorus, potassium, and the time of planting. Agronomy Journal. Madison, $63: 561-563$.

PEIXOTO, T.C., E. PATERNIANI e L.A. LOSCHIAVO, 1976. o efeito da introdução de poligenes para redução da parte das plantas de milho Izea mays L.l. Relatörio Cientifico do Instituto de Genëtica - ESALQ/USP. Piracicaba, 10:174-177. 
PENDLETON, J.W. e R.D. SEIF, 196I. Plant population and row spacing studies with brachytic 2 dwarf corn. Crop Science. Madison, $1: 433-5$.

PENDLETON, J.W., D.B. EGLI e D.B. PETERS, 1967. Response of Zea mays L. to a light rich field environment. Crop Science. Madison, 59:395-397.

PENDLETON, J.W., 1968. Light relationships and corn plant geometry. Proceedings of the $23^{\text {th }}$ Annual Corn and Sorghum Research Conferencé. Washington, 23:90-95.

PENDLETON, J.W., G.E. SMITH, S.R. WINTER e T.J. JOHNSTON, 1968. Field investigations of the relationships of leaf angle in corn. (Zea mays L.) to grain yield and apparent photosynthesis. Agronomy Journal. Madison, 60:422-424.

PIMENTEL GOMES, F., 1963. Curso de Estatistica Experimental. São Pau1o, Nobe1. 430 p.

POEY, F.R.D., 1973. Otra jornada en 1a Revolution Verde: Maices enanos en Mềxico. Agricultura de las Amëricas. Kansas City, 22, p. 20, 21, 38, 42 e 48 .

PONELEIT, C.G. e D.B. EGLI, 1979. Kernel growth rate and duration in maize as affected by plant density and genotype. Crop Science. Madison, 19:385-388. 
PONELEIT, C:G., D.B. EGLI, P.L. CORNELIUS e D.A. REICOSKY,

1980. Variation and assotiations of kernel growth

characteristics in maize populations. Crop Science.

Madison, 20:766-770.

POZAR, G., 1981. Interação da arquitetura da planta e espaçamento na produtividade do milho (Zea mays L.). Piracicaba, ESALQ/USP. (Tese de Mestrado). 75 .

PRINE, G.M., 1971. A critical period for ear development in maize. Crop Science. Madison, 11:782-786.

RAVEN, J.A. e S.M. GLIDEWELL, 1981..Process 1 imiting photosynthetic conductance. In: JOHNSON, C.V. Phisiological Processes Limiting Plant Productivity. Londres, Camelot press, F.109-136.

RISSI, R., G.P.VIEGAS, E. PATERNIANI e J.B. MIRANDA FILHO, 1976. Comportamento de híbridos e populações de milho l Zea mays L.) de porte baixo, em duas densidades de plantio e em quatro locais. Relatorio Cientifico Instituto de Gene tica-ESALQ/USP.: Piracicaba, 10:186-196.

ROOD, S.B. e D.J. MAJOR, 1981. Dialle1 analys is of leaf number, leaf' development rate, and plant height of early maturing maize. Crop Science. Madison, 21:867-873. 
RUSSEL, W.A., 1968. Testcrosses of one and two-ear types of corn belt maize inbreeds. I. Performance at four plant stand densities. Crop Science. Madison, 8:244-247.

RUSSEL, W.A., 1972. Effect of leaf angle on hybrid performance in maize (Zea mays L.). Crop Science. Madison, 90-92.

SAINI, S.S., 1976: Impact of semidwarfs on the area planted, production, and yield of rice in the Punjab of India. International Rice Research Newsletter. Monila, 3:2--3.

SANFORD, J.O., C.O. GROGAN, H.V. JORDAN e P.A. SARVELLA, 1965. Influence of male-sterility on nitrogen utilization in corn, Zea mays L. Agronomy Journal. Madison, 57:580-583.

SASS, J.E. e F.A. LOEFFEL, 1959. Development of axillary buds in maize in relation to barreness. Agronomy Journal. Madison, $51: 484-486$.

SAWAZAKI, E., 1980. Melhoramento da cultivar de milho 'IAC Maya'. Campinas, Fundação Cargil. 49 p.

SCARSBROOK, C.E. e B.D. DOSS, 1973. Leaf area index and radiation as related to corn yield. Agronomy Journal. Madis.on, $65: 459-461$. 
SCHIMIDT, W.H. e W.L. COLVILLE, 1967. Yield and iyeld componerits of Zea mays L. as influenced by artificially induced shade. Crop Science. Madison, 7:137-140.

SCOTT, G.E. e C.M. CAMPBELL, 1969. Internode lenght in normal and brachytic-2 maize inbreed and single crosses. Crop Science. Madison, 9:293-5.

SESTAK, Z., 1981. Leaf ontogeny and photosynthesis. In: JoHnson, C.B. Physiological Process Limiting P.lant Productivity. Londres, Camelot Press. p:147-158.

SIEMER, E.G., E.R. LENG e 0.T. BONNETT, 1969. Timing and correlation of major developmental events in maize, Zea mays L.. Agronomy Journal. Madison, 14:14-17.

SILVA, W.J., H. HIRATO, D.M. MEDINA e R.S. LONGO, 1976. Caracte rísticas anatômicas e morfológicas do novo cultivar de milho 'Erecta'. Ciência e Cultura.' São Paulo, 28:657-664.

SINGH, H. e B. RAI, 1979. Differences in morphological characters and yield of important maize genotypes and their recovered brachytic versions. Indian Journal of Agricultural Science. New De1hi, 49(10):758-63.

SINGLETON, W.R., 19599. Height potencial in brachytic-2 dwarf hybrids. Maize Genetics Cooperation News Letter. Columbia, $33: 3-4$. 
SOLONENKO, T.A. e T.S. CHALYK, 1975: A study of dwarf maize hybrids. Plant Breeding Abstracts. Londres, 45:279.

SOUZA Jr., C.L.; I.0. GERALDI e J.R. ZINSLY, 1981. Infiuência do tamanho do pendão na expressão da prolificidade em mi1ho (Zea mays L.). ReZatório Científico do Instituto de Ge. nética-ESALQ/USP. Piracicaba, 15:248-257.

SOUZA Jr., C.L. e J.R. ZINSLY, 1981. Avaliação de variedades de milho (Zea mays L.) braquítico-2 em cruzamentos dialéticos. Relatório Cientifico do Instituto de Genética, ESALQ/USP. Piracicaba, 15:271-284.

STEEL, R.G.D. e J.H. TORRIE, 1960. Principles and procedures of statistics. New York, McGraw-Hi11. 481 .

STEIN, 0.L., 1955. Rates of leaf initiation in two mutants of Zea mays L., dwarf-1 and brachytic-2. American Journal of Botany. Ba1timore, 42:885-892.

STINSON Jr., H.T. e D.N. MOSS, 1960. Some effects of shade upon corn hybrids tolerant and intolerant of dense planting. Agronomy Journal. Madison, 52:482-484.

TANNER, C.B., A.E. PETERSON e J.R. LOVE, 1960. Radiant energy exchange in a corn field. Agronomy Journal. Madison, $52: 373-379$. 
THOMPSON, J.C. e H.L. EVERETT, 1963: Brachytic-2 dwarf hybrids. Maize Genetics Cooperation News Letter. Columbia, $37: 20$.

TOLLENAAR, M., 1977. Sink-source relationships during reproductive development in maize. A review. Maydica. Bergamo, $12: 48-75$.

TOLLENAAR, M. e T.B. DAYNARD, 1978. Relationship between assimilate source and reproductive sink in maize grown in a shortseason environment. Agronomy Journal. Madison, $70: 219-223$.

TREBATH, B.R. e J.F., 1975. Leaf inclination and crop production. Field Crop Abstracts. Aberystwyth, 28:231-244.

TREGUBENKO, M.J. e V.I. NEPOMNJASCIJ, 1971. The water consuption of brachytic maize hybrids in relation to their yield. Plant Breeding Abstracts. Londres, 41:340.

TSOTSIS, B., 1972. Objectives of industry breeders to make efficient and significant advances in the future. Proceedings of the $27^{\text {th }}$ Annual Corn and Sorghum Research Conference. Washington, 27:93-107. 
YAO, A.Y.M. e R.H. SHAW, 1964. Effect of plant population and planting pattern of corn on water use and yield. Agronomy Journal. Madison, 56:147-152.

WILLIAMS, W.A., R.S. LOOMIS e C.R. LEPLEY, 1965. Vegetative growth of corn as affected by population density. I. Productivity in relation to interception of solar radiation. Crop Science. Madison, 5:211-215.

WILSON, D., 1981. Breeding for morphological and phýsiological traits. In: FREY, K.J. Plant Breeding II. Ames, Iowa. State Univ. Press., p.233-290.

WINTER, S.R. e A.J. OHLROGGE, 1973. Leaf angle, leaf area, and corn (Zea mays L.) yie1d. Agronomy Journal. Madison, $65: 395-397$

WIT, C.T., H.H. VANLAAR e H. VAN KEULEN, 1979. Physiological potentia1 of crop production. In: ZAADHANDEL, K.K. e D.J. HAVE. Plant Breeding Perspectives. Wageningen, Pudoc., $\mathrm{p} \cdot 47-77$.

WITTWER, S.H., 1974. Maximum production capacity of food crops. Bio Science. Washington, 24:216-224. 
.143.

APENDICE 
Tabela 4 - Valores médios de produção e acamamento obtidos de populações de milho normais e braquíticas, em quatro locais (Piracicaba, Matão, Guaíra e Ituiutaba), no ano agrícola $1981 / 82$.

\begin{tabular}{|c|c|c|c|c|c|c|}
\hline \multirow{3}{*}{$\begin{array}{l}\text { Popula- } \\
\text { çoes }\end{array}$} & \multicolumn{3}{|c|}{ Produção a $0 \%$ de umidade } & \multicolumn{3}{|c|}{ Acamamento (raiz + colmo) } \\
\hline & \multicolumn{2}{|c|}{$\mathrm{Kg} / \mathrm{ha}$} & \multirow{2}{*}{$\begin{array}{c}\text { Braq./Norm. } \\
\text { (\%) }\end{array}$} & \multicolumn{2}{|c|}{$\%$} & \multirow{2}{*}{$\begin{array}{c}\text { Braq./Norm. } \\
(\%)\end{array}$} \\
\hline & Normais & $\begin{array}{l}\text { Braquí- } \\
\text { ticas. }\end{array}$ & & Normais & $\begin{array}{l}\text { Braqui- } \\
\text { ticas }\end{array}$ & \\
\hline VD. 2 . & $4142 a$ & $4126 \mathrm{a}$ a & 99,6 & $31,8 \mathrm{abc}$ & $13,3 * *$ & 41,8 \\
\hline VF. 1 & $3873 a$ & $3850 b$ & 99,4 & $31,4 b c$ & $13,3 * *$ & 42,4 \\
\hline VD: 4 & $3823 a$ & $3625 c$ & 94,8 & $38,3 a$ & $9,8 * *$ & 25,6 \\
\hline VF. 3 & $3424 b$ & $3156 d$ & 92,2 & $36,6 a b$ & $13,1 * *$ & 35,8 \\
\hline Maya & $3977 a$ & $3872 b$ & 97,4 & $29,0 \mathrm{c}$ & $9,3 * *$ & 32,1 \\
\hline Médias & 3848 & 3726 & 96,7 & 33,4 & $11,8 * *$ & 35,3 \\
\hline
\end{tabular}

a/ Médias na mesma coluna seguidas pela mesma letra não diferem significativamente entre si, ao nível de 5\%, pelo teste de Duncan.

**Diferenças significativas ao nivel de $1 \%$, entre médias de um mesmo ęaracter em cada linha, pelo teste de F. 
Tabela 5 - Resumo das análises da variância para produção e acamamento de plantas (raiz + colmo), do ensaio competição de populações de milho normais e braquíticas. Resultados de quatro locais no ano agrícola 1981/82.

Fontes de variação
Quadrados, Médios
G.L.

Acamamento

$($ raiz + colmo $)$
Local (L)

Porte (P)

$P \times L$

Resîduo a
3

1

3

$8,2(19)$
$27,588586 \% *$

0,854611

0,813258

0,562388

$4,555721 *$

0,625950

0,518991

0,139502

$2,989507 \div *$

0,226815
$76,490162 * *$

$333,990092 * \%$

$8,892698 \% *$

1, 555813

\begin{tabular}{lrll} 
Variedade (V) & 4 & $4,555721 * *$ & 2,007651 \\
$\begin{array}{l}\text { V x L } \\
\text { Residuo b }\end{array}$ & 12 & 0,625950 & 1,176074 \\
\hline $\mathrm{P} \times \mathrm{V}$ & 76 & 0,518991 & 1,054945 \\
\hline $\mathrm{P} \times \mathrm{V} \times \mathrm{L}$ & 4 & 0,139502 & $2,382496 * *$ \\
Residuo C & 12 & $2,989507 * *$ & 0,572439 \\
\hline
\end{tabular}

C.V. a (\%)

c.V. b (\%)

C.V. C (\%)
13,01

19,02

12,58
27,96

23,02

19,38

a/Os nümeros entre parâmetros referem-se aos G.L. para acamamento (raiz $+\operatorname{colmo})$.

**Significativo ao nível de $1 \%$, pelo teste de F. 
Tabela 5a. - Desdobramento da análise da variância para produção e acamamento de plantas (raiz + colmo) para os efeitos de partes dentro de variedades e de varie dades dentro de portes.

\section{Quàdrados Médios}

Fontè de variação :G.L.

Produção $\begin{gathered}\text { Acamamento } \\ (\text { raiz }+ \text { colmo }) \text {. }\end{gathered}$

Porte/Variedade (P/V)

$\begin{array}{ccc}5 & & \\ 1 & 0,002817 & 46,395446 * * \\ 1 & 0,006106 & 46,667000 * * \\ 1 & 0,446105 & 111,343628 * * \\ 1 & 0,830270 & 74,330623 * * \\ 1 & 0,127313 & 64,783377 * * \\ 43,7(84,3) \text { al } & 0,294136 & 0,909422\end{array}$

$\mathrm{P} / \mathrm{V}-\mathrm{VD} .2$

$\mathrm{P} / \mathrm{V}-\mathrm{VF} . \mathrm{I}$

P/V.VD. 4

$\mathrm{P} / \mathrm{V}-\mathrm{VF} .3$

$\mathrm{P} / \mathrm{V}-\mathrm{Maya}$

Resíduo calculado

$43,7(84,3)$ aㅢ

0,002817

0,006106

0,446105

0,830270

0,294136
$46,667000 * *$

$11,343628 * *$

$74,330623 * *$

0,909422

Variedade/Porte $(V / P) \quad 3$
$\mathrm{V} / \mathrm{P}$ - a1to
$\mathrm{V} / \mathrm{P}$ - baixo
4
4
$1,633192 * *$
$3,062029 * *$
$2,558528 *$
- 1,831619

Resíduo calculado

$131,0(147,7)$

0,372903

0,901385

al Os nūmeros entre parênteses referem-se aos G.L. para acamamento (raiz + colmo).

*,**Significativo aos níveis de $5 \%$ e $1 \%$, respectivamente, pelo teste de F. 
Tabela 6 - Médias de acamamento pela raiz e quebra de colmo obtidas de populações de milho normais e braquiticas, em quatro locais (Piracicaba, Matão, Guaíra e Ituiutaba), no ano agrícola 1981/82.

\begin{tabular}{|c|c|c|c|c|c|c|}
\hline \multirow{3}{*}{$\underset{\text { P̧opula }}{\text { Popu }}$} & \multicolumn{3}{|c|}{ Acamamento de raiz } & \multicolumn{3}{|c|}{ Quebra de colmo } \\
\hline & \multicolumn{2}{|c|}{$\%$} & \multirow{2}{*}{$\begin{array}{c}\text { Braq./Norm } \\
(\%)\end{array}$} & \multicolumn{2}{|c|}{$\%$} & \multirow{2}{*}{$\underset{(\%)}{\text { Braq./Norm }}$} \\
\hline & Normais & $\begin{array}{l}\text { Braquí- } \\
\text { ticas }\end{array}$ & & Normais & $\begin{array}{l}\text { Braquỉ } \\
\text { ticas }\end{array}$ & \\
\hline VD. 2 & $10,4 a^{a} /$ & $4,8 * *$ & 46,2 & 21,4 & $8,4 * *$ & 39,2 \\
\hline$V F, 1$ & $8,3 a b$ & $3,3 * *$ & 39,8 & 23,1 & $9,9 * *$ & 42,9 \\
\hline VD. 4 & $12,0 a$ & $3,0 * *$ & 25,0 & 26,2 & $6,8 * *$ & 26,0 \\
\hline VF. 3 & $9,8 a$ & $2,6 * *$ & 26,5 & 26,7 & $10,4 * *$ & 39,0 \\
\hline Maya & $6,2 b$ & $2, I * *$ & 33,9 & 22,8 & $7,2 * *$ & 31,6 \\
\hline Médias & 9,4 & $3,2 * *$ & 34,0 & 24,1 & $8,6 * *$ & 35,7 \\
\hline
\end{tabular}

a/Médias na mesma coluna seguidas pela mesma letra não diferem significati vamente entre si, ao nível de 5\%, pelo teste de Duncan.

*,** Diferenças significativas ao nivel de $1 \%$, entre médias de um mesmo caracter em cada linha, pelo teste de F. 
Tabela 7 - Resumo das análises da variância para percentagem de plantas acamadas de raiz e percentagem de plan tas quebradas, do ensaio competição de populações de milhos normais e braquíticos. Resultados de quatro locais no ano agrícola 1981/82.

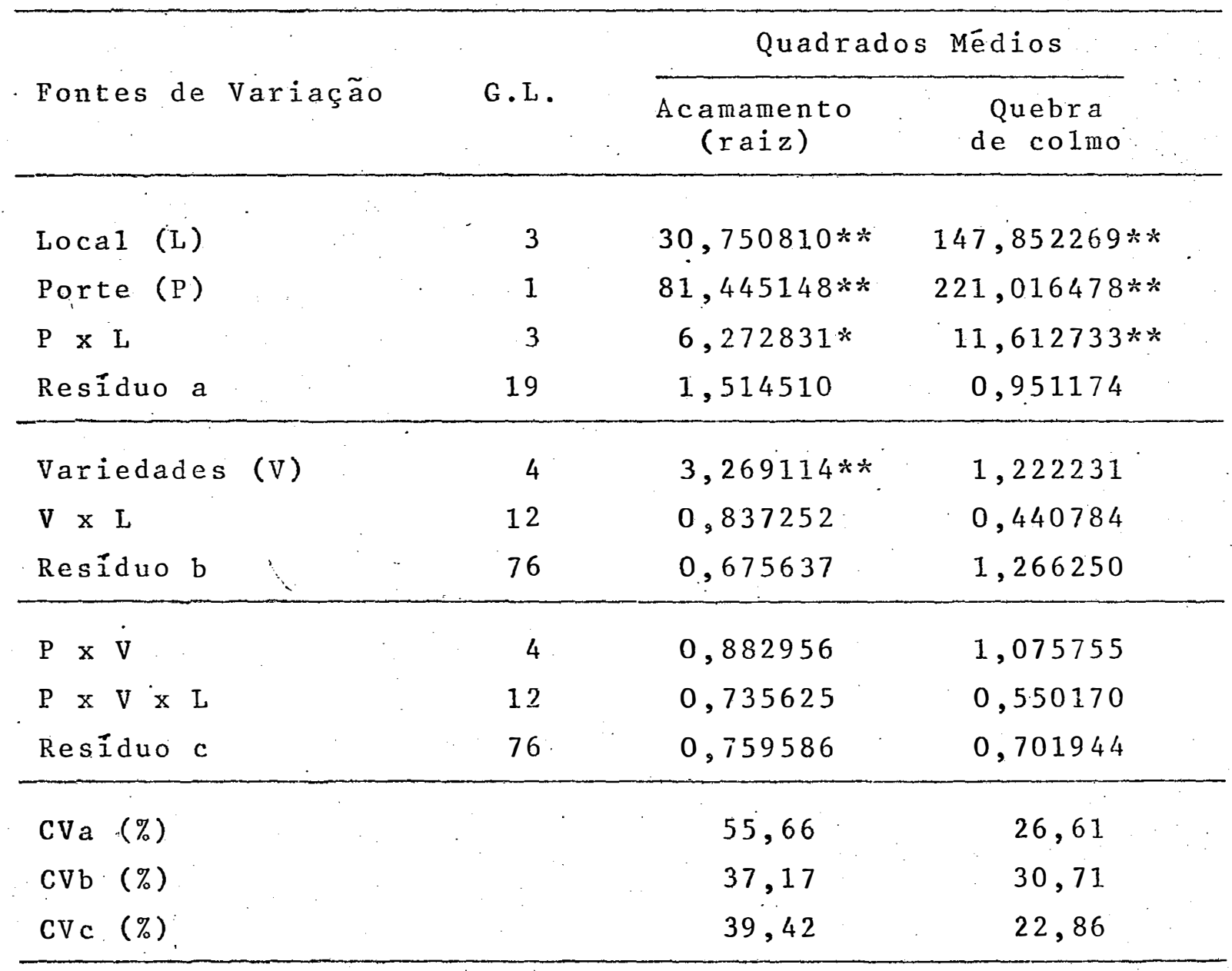

* **Significativo aos niveis de $5 \%$ e $1 \%$, respectivamente, pelo teste de F. 
Tabela $7 a$ - Desdobramento da anālise da variância para percentagem de plantas acamadas de raiz e percentagem de plantas quebradas, para os efeitos de portes dentro de variedades e de variedades dentro de portes.

\begin{tabular}{|c|c|c|c|}
\hline \multirow[b]{2}{*}{ Fontes de Variação } & \multirow[b]{2}{*}{ G.L. } & \multicolumn{2}{|c|}{ Quadrados Médios } \\
\hline & & $\begin{array}{l}\text { Acamamento } \\
(\text { raiz) }\end{array}$ & $\begin{array}{l}\text { Quebra de } \\
\text { colmo }\end{array}$ \\
\hline Porte/Variedade (P/V) & 5 & $\therefore$ & : \\
\hline $\begin{array}{r}P / V-V D .2 \\
P / V-V F .1 \\
P / V-V D .4 \\
P / V-V F .3 \\
P / V-M a y a\end{array}$ & $\begin{array}{l}1 \\
1 \\
1 \\
1 \\
1\end{array}$ & $\begin{array}{r}10,483036 * * \\
16,401501 * * \\
27,650144 * * \\
21,386021 * * \\
9,056272 * *\end{array}$ & $\begin{array}{l}32,500790 * * \\
32,115116 * * \\
66,704973 * * \\
49,184278 * * \\
44,814340 *\end{array}$ \\
\hline Residuo calculado & $85,6(93,4)$ al & 0,910571 & 0,751790 \\
\hline Variedade/Porte (V/P) & 8 & & \\
\hline $\begin{array}{l}V / P-\text { a } 1 \text { to } \\
V / P-\text { baixo }\end{array}$ & $\begin{array}{l}4 \\
4\end{array}$ & $\begin{array}{l}2,861643 * * \\
1,290445\end{array}$ & $\begin{array}{l}1,442574 \\
0,855412\end{array}$ \\
\hline Resíduo calculado & $151,5(140,4)$ & 0,717612 & 0,984097 \\
\hline
\end{tabular}

a/ Os numeros entre parênteses referen-se aos G.L. para quebra de colmo.

**Significativo ao nive1 de $1 \%$, pelo teste de F. 
Tabela 8 - Valores médios de altura da planta e da espiga obti dos de populações de milho normais. e braquíticas, em quatro locais (Piracicaba, Matão, Guaíra e Ituiu taba), no ano agrícola 1981/82.

\begin{tabular}{|c|c|c|c|c|c|c|}
\hline \multirow{3}{*}{ 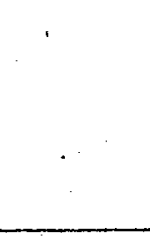 } & \multicolumn{3}{|c|}{ Altura da Planta } & \multicolumn{3}{|c|}{ A1tura da Espiga } \\
\hline & \multicolumn{2}{|c|}{$\mathrm{cm}$} & \multirow{2}{*}{$\begin{array}{c}\text { Braq. / Norm. } \\
(\%)\end{array}$} & \multicolumn{2}{|c|}{$\mathrm{cm}$} & \multirow{2}{*}{$\begin{array}{c}\text { Braq. /Norm. } \\
(\%)\end{array}$} \\
\hline & Normais & $\begin{array}{l}\text { Braquí- } \\
\text { ticas } \\
\end{array}$ & & Normais & $\begin{array}{c}\text { Braqui- } \\
\text { ticas }\end{array}$ & \\
\hline VD. 2 & $246,0 \mathrm{ab}^{\mathrm{a} /}$ & $173,8 \mathrm{ab} * *$ & $.70,6$ & $155,1 b c$ & $98,6 a * *$ & 63,6 \\
\hline VF. 1. & $239,3 b$ & $169,5 a b c * *$ & 70,8 & $143,1 d$ & $91,7 \mathrm{~b} * *$ & 64,1 \\
\hline VD. 4 & $247,0 \mathrm{ab}$ & $167,4 \mathrm{bc} * *$ & 67,8 & $158,5 b$ & $9 \mathrm{I}, 2 \mathrm{~b} \mathrm{c} * *$ & 57,5 \\
\hline VF. 3 & $240,4 b$ & $164,1 \mathrm{c} * *$ & 68,3 & $150,2 c$ & $85,5 c x *$ & 56,9 \\
\hline Maya & $257,9 a$ & $174,2 \mathrm{a} * *$ & 67,6 & $170,6 a$ & $86,8 b \mathrm{c} * *$ & 50,9 \\
\hline Médias & 246,1 & $169,8 * *$ & 69,0 & 155,5 & $90,8 * *$ & 58,4 \\
\hline
\end{tabular}

a/Médias na mesma coluna seguidas pela mesma letra não diferem significativamente entre si, ao níve1 de $5 \%$, pelo teste de Duncan.

**Diferenças significativas ao nível de $1 \%$, entre médias de um mesmo caracter em cada linha, pelo teste de $\mathrm{F}$. 
Tabela 9 - Resumo das análises de variância para altura da plan ta e altura da espiga, do ensaio Competição de Popu lações de Milho Normais e Braquíticas. Resultados de quatro locais no ano agrícola $1981 / 82$.

\begin{tabular}{|c|c|c|c|}
\hline \multirow[b]{2}{*}{ Fontes de Variação } & \multirow[b]{2}{*}{ G.L. } & \multicolumn{2}{|c|}{ Quadrados Médios } \\
\hline & & $\begin{array}{l}\text { Altura da } \\
\text { planta }\end{array}$ & $\begin{array}{l}\text { Altura da } \\
\text { espiga }\end{array}$ \\
\hline Local (L) & 3 & $15.779,883 * *$ & $15.763,694 \% *$ \\
\hline Porte (P) & 1 & $349.683,011 * *$ & $251.294 .817 * *$ \\
\hline$P \times L$ & 3 & $6.166,503 * *$ & $995,428 *$ \\
\hline Resíduo a & 20 & 358,138 & 198,285 \\
\hline Variedades (V) & 4 & $1.385,225 * *$ & I. $304,025 * \%$ \\
\hline$V \times L$ & 12 & 111,989 & 112,597 \\
\hline Resíduo b & 80 & 166,434 & 97,663 \\
\hline$P \times V$ & 4 & $369,200 * \%$ & $1.841,379 * \%$ \\
\hline$P \quad x \quad y \quad x \quad L$ & 12 & $637,841 * *$ & $16.718,165 * *$ \\
\hline Resíduo c & 80 & 80,294 & 87,701 \\
\hline $\mathrm{CVa}(\%)$ & & 9,10 & 11,44 \\
\hline $\mathrm{cV} b \quad(\%)$ & & 6,20 & 8,02 \\
\hline $\mathrm{CV} c(\%)$ & & 4,31 & 7,60 \\
\hline
\end{tabular}

*,**Significativo aos níveis de $5 \%$ e $1 \%$, respectivamente, pe10 teste de F. 
Tabela 9a - Desdobramento da anālise da variância para altura da planta e altura da espiga, para os efeitos de portes dentro de variedades e de variedades dentro de porte.

\begin{tabular}{lccc}
\hline Fontes de Variaço & G.L. & Quadrados Médios \\
\cline { 3 - 4 } & & Altura da & $\begin{array}{c}\text { Altura da } \\
\text { elanta }\end{array}$ \\
Porte/Variedade(P/V) & 5 & & \\
P/V-VD.2 & 1 & $-62.568,521 * *$ & $38.363,521 * *$ \\
P/V-VF.1 & 1 & $58.590,188 * *$ & $31.724,083 * *$ \\
P/V-VD.4 & 1 & $76.002,083 * *$ & $54.203,521 * *$ \\
P/V-VF.3 & 1 & $69.997,688 * *$ & $50.116,688 * *$ \\
P/V-Maya & 1 & $84.001,333 * *$ & $84.252,521 * *$ \\
Residuo calculado & $59,9(86,0)$ a / & 135,823 & 109,818 \\
\hline Variedade/Porte(V/P) & 8 & & \\
V/P - alto & 4 & $1.307,9.46 * *$ & $2.515,458 * *$ \\
V/P - baixo & 4 & $446,479 * *$ & $629,946 * *$ \\
Residuo calculado & $142,6(159,5)$ & 123,364 & 92,682 \\
\hline
\end{tabular}

a/Os números entre parênteses referem-se aos G.L. apenas para altura da espiga.

**Significativo ao nível de $1 \%$, pelo teste de F. 
Tabela 10 - Valores médios para o indice AE/AP (posição relatị va da espiga) e número de espigas por planta de po pulações de milho normais e braquíticas, em quatro locais (Piracicaba, Matão, Guaíra e Ituiutaba), no ano agrícola $1981 / 82$ :

\begin{tabular}{|c|c|c|c|c|c|c|}
\hline \multirow{2}{*}{$\begin{array}{c}\text { Popula } \\
\text { çôes }\end{array}$} & \multicolumn{3}{|c|}{ Indice $\mathrm{AE} / \mathrm{AP}$} & \multirow{2}{*}{$\frac{\text { No de }}{\text { Normais }}$} & \multicolumn{2}{|c|}{ Espigas por Planta } \\
\hline & Normais & $\begin{array}{l}\text { Braquí- } \\
\text { ticas }\end{array}$ & $\begin{array}{c}\text { Braq. }_{(\%)} \text { /Norm. } \\
.\end{array}$ & & $\begin{array}{l}\text { Braquí- } \\
\text { ticas }\end{array}$ & $\begin{array}{c}\text { Braq. / Norm. } \\
(\%)\end{array}$ \\
\hline VD. 2 & $0,63 a b \stackrel{a}{ }$ & $0,56 a * *$ & 88,9 & $0,94 \mathrm{bc}$ & $1,02 a *$ & * 108,5 \\
\hline VF. 1 & $0,59 c$ & $0,54 a b * *$ & 91,5 & $1,07 a$ & $1,04 a$ & 97,2 \\
\hline VD. 4 & $0,64 \mathrm{ab}$ & $0,54 \mathrm{ab} * *$ & 84,4 & $0,86 \mathrm{c}$ & $0,89 c$ & 103,5 \\
\hline VF. 3 & $0,62 b$ & $0,52 b c * *$ & 83,9 & $0,90 b c$ & $0,93 b c$ & 103,3 \\
\hline Maya & $0,65 a$ & $0,50 c * *$ & 76,9 & $0,96 b$ & $0,98 a b$ & 102,1 \\
\hline Médias & 0,63 & $0,53 * *$ & 84,1 & 0,95 & 0,97 & 102,1 \\
\hline
\end{tabular}

a/ Médias na mesma coluna seguidas pela mesma letra não diferem significati vamente entre si, ao nível de 5\%, pelo teste de Duncan.

*, **Diferenças significativas aos níveis de $5 \%$ e $1 \%$, respectivamente, entre médias de um mesmo carácter em cada linha, pelo teste de F. 
Tabela 11 - Resumo das anālises da variância para o Indice AE/AP e número médio de espigas por planta, do ensaio Competição de Populações de Milho Normais e Braquiticas. Resultados de quatro locais no ano agrícola $1981 / 82$.

\begin{tabular}{|c|c|c|c|}
\hline \multirow{2}{*}{ Fontes de Variação } & \multirow[b]{2}{*}{ G.L. } & \multicolumn{2}{|c|}{ Quadrados Médios } \\
\hline & & Indice $\mathrm{AE} / \mathrm{AP}$ & $\begin{array}{l}\text { No de espigas } \\
\text { por planta }\end{array}$ \\
\hline Local (L) & 3 & $0,081327 * *$ & $0,479758 * *$ \\
\hline Porte (P) & 1 & $0,568427 * *$ & 0,035284 \\
\hline$P \times L$ & 3 & 0,007072 & 0,044614 \\
\hline Resíduo a & 20 & 0,002600 & 0,020593 \\
\hline Variedade (V) & 4 & $0,007171 * *$ & $0,230919 * *$ \\
\hline $\mathrm{V} \times \mathrm{L}$ & 12 & 0,001706 & 0,031096 \\
\hline Resíduo b & 80 & 0,000965 & 0,021055 \\
\hline $\mathrm{P} \times \mathrm{V}$ & 4 & $0,021589 * *$ & 0,018022 \\
\hline$P \times V \times L$ & 12 & $0,004034 * *$ & 0,020961 \\
\hline Resíduo c & 80 & 0,001543 & 0,015241 \\
\hline $\begin{array}{l}\text { CVa }(\%) \\
\text { CVb }(\%) \\
\text { CVc }(\%)\end{array}$ & & $\begin{array}{l}8,78 \\
5,35 \\
6,76\end{array}$ & $\begin{array}{l}14,95 \\
15,10 \\
12,86\end{array}$ \\
\hline
\end{tabular}

* *Significativo ao nível de $1 \%$, pelo teste de $F$. 
Tabela 11a - Desdobramento da anälise da variância para o indi ce $\mathrm{AE} / \mathrm{AP}$ e nümero médio de espigas por planta, pa ra os efeitos de portes dentro de variedades e de variedades dentro de portes.

\begin{tabular}{|c|c|c|c|}
\hline \multirow[b]{2}{*}{ Fontes de Variação } & \multirow[b]{2}{*}{ G.L. } & \multicolumn{2}{|c|}{ Quadrados Médios } \\
\hline & & Indice $\mathrm{AE} / \mathrm{AP}$ & $\begin{array}{l}\text { No de espigas } \\
\text { por planta }\end{array}$ \\
\hline Porte/Variedade (P/V) & 5 & . & \\
\hline $\begin{array}{l}\mathrm{P} / \mathrm{V}-\mathrm{VD} .2 \\
\mathrm{P} / \mathrm{V}-\mathrm{VF} .1 \\
\mathrm{P} / \mathrm{V}-\mathrm{VD} .4 \\
\mathrm{P} / \mathrm{V}-\mathrm{VF} .3 \\
\mathrm{P} / \mathrm{V}-\mathrm{M} \text { aу }\end{array}$ & $\begin{array}{l}1 \\
1 \\
1 \\
1 \\
1\end{array}$ & $\begin{array}{l}0,050052 * * \\
0,039675 * * \\
0,119002 * * \\
0,121002 * * \\
0,325052 * *\end{array}$ & $\begin{array}{l}0,083333^{*} \\
0,007752 \\
0,007252 \\
0,005002 \\
0,004033\end{array}$ \\
\hline Résíduo calculado & $94,5(98,3)$ & 0,001755 & 0,016312 \\
\hline Variedade/Porte (V/P) & 8 & & \\
\hline $\mathrm{V} / \mathrm{P}-\mathrm{a} 1$ to & 4 & $0,013740 * \%$ & $0,144986 * *$ \\
\hline $\mathrm{V} / \mathrm{P}-\mathrm{baixo}$ & 4 & $0,015020 * *$ & $0,103955 * *$ \\
\hline Residuo calculado. & $151,9(156,0)$ & 0,001254 & 0,018148 \\
\hline
\end{tabular}

a/Os números entre parênteses referem-se aos G.L. apenas para número de espigas por planta.

*,**Significativo aos níveis de $5 \%$ e $1 \%$, respectivamente, pe 10 teste de F. 
Tabela 12 - Valores médios em nümero de dias para o florescimento masculino e intervalo entre o florescimento masculino ( $\delta$ ) e feminino (q). Dados obtidos de po pulações de milho normais e braquíticas, em dois locais (Piracicaba e Matão) no ano agrícola 1981/82.

\begin{tabular}{|c|c|c|c|c|c|c|}
\hline \multirow{3}{*}{$\begin{array}{l}\text { Popula- } \\
\text { çôes }\end{array}$} & \multicolumn{3}{|c|}{$\begin{array}{r}\text { Periodo para } 0 \\
\text { florescimento } 0^{\prime \prime} \\
\end{array}$} & \multicolumn{3}{|c|}{$\begin{array}{l}\text { Intervalo entre }{ }^{\circ} \text { a/" } \\
\text { flores cimento o }{ }^{\prime \prime} \text { e }\end{array}$} \\
\hline & \multicolumn{2}{|c|}{ dias } & \multirow{2}{*}{ Braq. /Norm. } & \multicolumn{2}{|c|}{ dias } & \multirow{2}{*}{$\begin{array}{c}\text { Braq. /Norm } \\
(\%)\end{array}$} \\
\hline & Normais & $\begin{array}{l}\text { Braqui- } \\
\text { ticas }\end{array}$ & & Normais & $\begin{array}{c}\text { Braqui- } \\
\text { ticas }\end{array}$ & \\
\hline VD. 2 & $74,4 b^{b} /$ & $75,6 a b$ & 101,6 & 2,4 & $1,2 c * *$ & 50,0 \\
\hline VF. 1 & $72,0 c$ & $74,4 b * *$ & 103,3 & 3,0 & $2,6 a b$ & 86,7 \\
\hline VD. 4 & $75,9 a$ & $76,1 a$ & 100,3 & 2,8 & $2,6 a b$ & 92,9 \\
\hline VF. 3 & $73,9 \mathrm{~b}$ & $74,2 b$. & 100,4 & 3,6 & $3,6 a$ & 100,0 \\
\hline Maya & $76,4 a$ & $74,8 \mathrm{ab} *$ & 97,9 & 2,4 & $2,0 \mathrm{bc}$ & 83,3 \\
\hline Médias & 74,5 & 75,0 & 100,7 & 2,8 & 2,4 & 85,7 \\
\hline
\end{tabular}

a' Dados obtidos apenas em Piracicaba.

b/Médias na mesma coluna seguidas pela mesma letra não diferem significati vamente, entre si, ao nível de 5\%, pelo teste de Duncan.

*,**Diferenças significativas aos niveis de $5 \%$ e $1 \%$, respectivamente, entre médias de um mesmo caracter em cada 1inha, pelo teste de F. 
- Tabela 13. - Resumo das análises da variância para número de dias para o florescimento masculino ( $\sigma^{\circ}$ ) e interva1o em dias entre o florescimento masculino ( $\left.\sigma^{\circ}\right)$ e feminino $(q)$. Resultados do Ensaio Competição de Populações de Milho Normais e Braquiticos realizado em dois locais no ano agrícola 1981/82.

\begin{tabular}{|c|c|c|c|}
\hline & $\cdot$ & Quadrad & s Médios \\
\hline Fontes de Variação & G.L. & $\begin{array}{l}\text { No de dias para o } \\
\text { florescimento o }\end{array}$ & $\begin{array}{c}\text { Intervalo entre o } \\
\text { floresc. } \delta^{\sharp} \text { e } q\end{array}$ \\
\hline Loca1 (L) & 1 & $4,285185 * *$ & \\
\hline Porte (P) & $1(1) \underline{a} /$ & 0,022583 & 0,244841 \\
\hline$P \times L$ & 1 & 0,003599 & \\
\hline Resíduo a & $9(4)$ & 0,005054 & 0,047492 \\
\hline Variedade (V) & $4(4)$ & $0,089386 * *$ & 0,399681 \\
\hline $\mathrm{V} \times \mathrm{x}$ & 4 & $0,017705^{*}$ & \\
\hline Resíduo b & $36(16)$ & 0,005980 & 0,155033 \\
\hline $\mathrm{P} \times \mathrm{V}$ & $4(4)$ & $0,037738 * x$ & 0,059671 \\
\hline$P \times V \times L$ & 4 & 0,009889 & . \\
\hline Resíduo c & $36(16)$ & 0,007758 & 0,034109 \\
\hline $\mathrm{CVa}(\%)$ & & 0,82 & 12,57 \\
\hline $\mathrm{CVb}(\%)$ & & 0,89 & 22,71 \\
\hline $\mathrm{CVc}(\%)$ & & 1,02 & 10,65 \\
\hline
\end{tabular}

al Os números entre parênteses referem-se aos G.L. para o intervalo entre o florescimento $\sigma^{7} \mathrm{e} q$, cujos dados foram obtidos em apenas um local.

*,**Significativo aos nî̀eis de $5 \%$ e $1 \%$, respectivamente,pelo teste de F. 
Tabela 13a - Desdobramento da análise da variância para o núme ro de dias para o florescimento masculino e inter valo em dias entre o florescimento masculino e feminino, para os efeitos de porte dentro de va riedade e variedades dentro de porte.

\section{Quadrados Médios}
Fontes de Variação
G.L.
No de dias para Intervalo entre o
o floresc. or floresc. $\sigma^{\pi}$ e $q$
Porte/Variedade $(\mathrm{P} / \mathrm{V}) \quad 5$
$\mathrm{P} / \mathrm{V}-\mathrm{VD} .2$
$\mathrm{P} / \mathrm{V}-\mathrm{VF} .1$
$1 \quad 0,025059$
$0,386420 * *$
$\mathrm{P} / \mathrm{V}-\mathrm{VD} .4$
$1 \quad 0,104191 * *$
0,029277
$\mathrm{P} / \mathrm{V}-\mathrm{VF} .3$
0,000116
0,008392
$\mathrm{P} / \mathrm{V}$-Maya
$1 \quad 0,002363$
0,000433
1
0,041804 *
0,059002
Resíduo calculado
$44,0(19,0)$ al
0,007217
0,036785

$\begin{array}{ccll}\text { Variedade/Porte (V/P) } & 8 & & \\ \text { V/P - alto } \quad & 4 & 0,107501 * * & 0,090820 \\ \text { V/P - baixo } & 4 & 0,019623^{*} & 0,368530^{*} \\ \text { Resíduo calculado } & 70,8(22,7) & 0,006869 & 0,094572\end{array}$

al os nümeros entre parênteses referem-se aos G.L. apenas para o intervalo entre o florescimento masculino e feminino, cujos dados foram obtidos em um ünico local.

*,**Significativo aos niveis de $5 \%$ e $1 \%$, respectivamente, pelo testa de $\mathrm{F}$. 
Tabela 14 - Valores médios para número de ramificações do pendão e percentagem de espigas pendentes, obtidos de populações de milho normais e braquíticas em Piracicaba e Matão no ano agrícola 1981/82.

\begin{tabular}{|c|c|c|c|c|c|c|}
\hline \multirow{3}{*}{$\begin{array}{l}\text { Popula } \\
\text { ções }\end{array}$} & \multicolumn{3}{|c|}{ Ramificações do Pendão } & \multicolumn{3}{|c|}{ Espigas pendentes- al } \\
\hline & \multicolumn{2}{|c|}{ No } & \multirow{2}{*}{$\begin{array}{c}\text { Braq. /Norm. } \\
(\%)\end{array}$} & \multicolumn{2}{|c|}{$\%$} & \multirow{2}{*}{$\begin{array}{c}\text { Braq./Norm. } \\
(\%)\end{array}$} \\
\hline & Normais & $\begin{array}{l}\text { Braquí- } \\
\text { ticas }\end{array}$ & & Normais & $\begin{array}{l}\text { Braquí- } \\
\text { ticas }\end{array}$ & \\
\hline VD. 2 & $22,9 \mathrm{cb}-$ & $20,4 c^{* *}$ & 89,1 & 32,9 & $18,0 * *$ & 54,7 \\
\hline VF. 1 & $28,6 \mathrm{~b}$ & $27,8 a$ & 97,2 & 37,4 & $14,8^{* *}$ & 39,6 \\
\hline VD. 4 & $24,7 \mathrm{c}$ & $22,3 b^{* *}$ & 90,3 & 30,0 & $12,5 * *$ & 41,7 \\
\hline VF. 3 & $32,6 a$ & $27,7 \mathrm{a} * *$ & 85,0 & 28,5 & $13,7 * *$ & 48,1 \\
\hline Maya & $22,6 d$ & $18,6 c * *$ & 82,3 & 31,9 & $15,0 * *$ & 47,0 \\
\hline Médias & 26,2 & $23,4 * *$ & 89,3 & 32,1 & $14,8 * *$ & 46,1 \\
\hline
\end{tabular}

a/ Dados obtidos apenas em Piracicaba.

b/Médias na mesma coluna seguidas pela mesma letra não diferem significativamente entre si, ao nível de 5\%, pelo teste de Duncan.

**Diferenças significativas a nível de $1 \%$, entre médias de um mesmo caracter em cada linha, pelo teste de F. 
- Tabela 15. - Resumo das anāiises da variância para número de ra mificações do pendão e percentagem de espigas pendentes do ensaio de Competição.de Populações de Mí Tho Normais e Braquiticas. Resultados de dois lo cais no ano agrícola 1981/82.

\begin{tabular}{|c|c|c|c|c|}
\hline \multirow[b]{2}{*}{ Fontes de } & \multirow[b]{2}{*}{ Variação } & \multirow[b]{2}{*}{ G.L. } & \multicolumn{2}{|c|}{ Quadrados Médios } \\
\hline & & & $\begin{array}{c}\text { Ramificações } \\
\text { do pendão }\end{array}$ & $\begin{array}{c}\text { Espigas } \\
\text { pendentes }\end{array}$ \\
\hline$\therefore$ & & & & \\
\hline Local (L) & & $1 \div$ & $357,7653.3 * *$ & \\
\hline Porte (P) & & $1(1)$ a & $247,68133 * *$ & 39,32305 \\
\hline $\mathrm{P} \times \mathrm{L}$ & & 1 & 0,76800 & \\
\hline Resíduo a & & $10(4)$ & 2,43822 & 0,91077 \\
\hline Variedade & ( v). & $4(4)$ & $416,52283 * *$ & 0,65316 \\
\hline V $\times$ L & 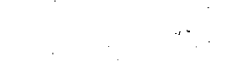 & 4 & 4,15117 & \\
\hline Resíduo b & $\therefore$ & $40(16)$ & 5,30216 & $0,61888^{\circ}$ \\
\hline $\mathbf{P} \mathbf{x} \quad \mathbf{V}$ & & $4(4)$ & $57,22200 * *$ & 0,20514 \\
\hline$P \times V \times L$ & . & 4 & 0,28393 & \\
\hline Resíduo c & & $40(16)$ & 4,77830 & 0,55533 \\
\hline CVa $(\%)$ & 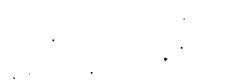 & & 6,30 & 20,09 \\
\hline cVb (\%) & & . & 9., 28 & 16,56 \\
\hline CVc $(\%)$ & & . & 8,81 & 15,68 \\
\hline
\end{tabular}

a/ Os nümeros entre parênteses referem-se aos G.L. para espigas pendentes, cujos dados foram obtidos em apenas um 10cal.

**Significativo ao nivel de $1 \%$, pelo teste de F. 
Tabela 15a - Desdobramento da anāiise da variância para o nūme ro de ramificações do pendão e percentagem de espigas pendentes, para os efeitos de porte dentro de variedade e variedade dentro de porte.

\begin{tabular}{|c|c|c|c|}
\hline \multirow[b]{2}{*}{ Fontes de Variação } & \multirow[b]{2}{*}{ G.L. } & \multicolumn{2}{|c|}{ Quadrados Médios } \\
\hline & & $\begin{array}{l}\text { Ramificações } \\
\text { do pendão }\end{array}$ & $\begin{array}{l}\text { Espigas } \\
\text { pendentes }\end{array}$ \\
\hline Porte/Variedade (P/V) & 5 & & \\
\hline $\begin{array}{l}P / V-V D .2 \\
P / V-V F .1 \\
P / V-V D .4 \\
P / V-V F .3 \\
P / V-M a y a\end{array}$ & $\begin{array}{l}1 \\
1 \\
1 \\
1 \\
1\end{array}$ & $\begin{array}{r}38,00167 * * \\
3,52667 \\
35,04167 * * \\
140,16667 * * \\
88,16667 * *\end{array}$ & $\begin{array}{r}5,64105 * * \\
12,24112 * * \\
9,00540 * * \\
6,28199 * * \\
6,97405 * *\end{array}$ \\
\hline Resíduo calculado & $47,7(19,0)$ a/ & 4,31103 & 0,60642 \\
\hline Variedade/Porte (V/P) & 8 & & \\
\hline $\begin{array}{l}V / P-\text { alto } \\
V / P-\text { baixo }\end{array}$ & $\begin{array}{l}4 \\
4\end{array}$ & $\begin{array}{l}218,41433 * * \\
212,41400 * *\end{array}$ & $\begin{array}{l}0,50062 \\
0,35768\end{array}$ \\
\hline Resíduo calculado & $79,8(31,9)$ & 5,04023 & 0,587105 \\
\hline
\end{tabular}

alos números entre parênteses referem-se aos G.L. apenas para espigas pendentes, cujo dados foram obtidos em um único 1ocal.

**Significativo ao nível de $1 \%$, pelo teste de F. 